\title{
Neutrality, Legitimacy, and the Supreme Court: Some Intersections Between Law and Political Science
}

\author{
Jan G. Deutsch*
}

I.

The work of Professor Martin Shapiro is distinguished by lucidity, an analytical turn of mind, formidable sophistication, and a thoroughly readable style. A political scientist by training, Shapiro is very much at home with the tools and techniques of the lawyer. His flair for case analysis is much in evidence in Law and Politics in the Supreme Court. In the chapters on tax and labor policy, for example, his view of the Court as a political agency furthering its interests through interaction with other agencies such as the Internal Revenue Service and the National Labor Relations Board is developed through close readings of decisions ${ }^{2}$ and comparisons among groups of cases. ${ }^{3}$ Indeed, Shapiro's analysis of the reapportionment controversy demonstrates a regard for lawyers' sensibilities seemingly above and beyond the call of duty-considerably more than half the chapter is devoted to a closely reasoned parsing of the "political question" cases."

Shapiro's regard for "lawyer's law," however, is only apparently excessive. His focus on the interaction among governmental agencies inevitably involves consideration of cases in which the Court paces the boundaries of its own jurisdiction. And as Professor Bickel's work in The Least Dangerous Branch ${ }^{5}$ testifies, this judicial mapping of spheres of competence is preeminently "lawyer's law," with compass directions provided in the arcane terminology of "case and controversy," "standing," and "ripeness." Yet it is precisely here that Shapiro breaks decisively with conventional legal approaches.

Shapiro denominates his view "political jurisprudence." Postulating

- A.B. I955, LL.B. I962, Ph.D. I962, Yale University. Associate Professor of Law, Yale University. Anything of value in this Article owes much to three men associated with the Stanford Law School: Jared G. Carter, formerly assistant professor of law, who first suggested many of these ideas to me; Professor William F. Baxter, who helped me to refine them in the course of long and, at least on his side, gracious conversations; and Dean Bayless A. Manning, who first afforded me the opportunity of offering the seminar in which they were developed.

1. M. Shapmo, Law and Politics in the Supreade Court: New Approaches to Poltitcal JURISPRUDENCE ( 1964$)$.

2. See, e.g., id. at 107-09.

3. See, e.g., id. at $113-24$.

4. Id. at $175-216$. $(1962)$.

5. A. Bickel, The Least Dangerous Branch: The Supreme Court at the Bar of Politics

6. M. Shupiro, supra note I, at 15 . 
that Court opinions represent political decisions embodying the policy preferences of the Justices, he perceives the doctrines surveyed by Bickel as political accommodations between the judiciary and rival centers of political power. Devotees of polemical literature concerning the Court will recognize this delineation.

The starting point for the recent debate has been Judge Hand's eloquent Holmes Lectures. In those lectures, Hand confessed his inability satisfactorily to justify a doctrine of judicial review that enables a Court not responsible to the electorate to nullify acts of political agencies deriving their powers directly from that electorate. ${ }^{7}$ Professor Wechsler's essay on neutral principles, by rooting the power of judicial review in the text of the Constitution itself,, attempts to lay the ghost of judicial usurpation raised by Hand.

Shapiro, so to speak, stands Hand on his head. He accepts as givenas the normal state of affairs-the very attempt by the Court to substitute its policy preferences for those of the political agencies that Hand found so difficult to justify even in exceptional circumstances. Shapiro's characteristically trenchant assessment of the Court's need for neutral principles defines the gulf that separates his starting point from those of Hand and Wechsler.

To put it bluntly, the real problem is how the Supreme Court can pursue its policy goals without violating those popular and professional expectations of "neutrality," which are an important factor in our legal tradition and a principal source of the Supreme Court's prestige. It is in these terms, not in terms of the philosophic, jurisprudential, or historical correctness of the concept of neutral principles, that the debate should now proceed. ${ }^{10}$

Demonstration of the superiority of one or another theory about the role of the Court hinges upon the understanding such a theory affords of the results embodied in particular decisions. Shapiro's most recent book ${ }^{11}$ advocates more vigorous implementation of first amendment guarantees than would be deemed proper by Hand, Wechsler, or Justice Frankfurtera group whose reiterated concern that the Court might be overstepping the legitimate boundaries of its authority leads Shapiro to designate them the "modest."12 That Shapiro regards this difference in attitude toward the first amendment as dependent upon differences between his theory of judicial review and that espoused by the "modest" is clear. The introduc-

7. See L. HANd, ThE BIII OF Rights I-30 (1958).

8. See H. WeChSLER, Toward Neutral Principles of Constitutional Law, in Principles, Potrrics, aNd FUndaMental LaWW 3, 4-15 (1961).

9. See L. Hand, supra note 7, at I-30, 56-77.

IO. M. SHAPIRo, supra note I, at 3 I.

II. M. Shapiro, Freedom of Speech: The Supreme Court and Judictal Review (xg66).

I2. See id. at ro8-II. 
tory section of his book concludes: "Having cleared away the hesitancies of judicial modesty, it is possible to proceed to the problem of what level of protection the Supreme Court ought to give freedom of speech."1s

The first amendment, however, does not provide a satisfactory area in which to demonstrate Shapiro's thesis more successful than the "modest" view. True, much of the opposition to the Hand and Wechsler positions came from those who approved results reached by the Court in decisions that both Hand and Wechsler found illegitimate. And Shapiro does arrive at first amendment conclusions considerably divergent from those reached by the judge and the professor. But we are not justified in regarding one view of the judicial role as more valuable than another simply because it, more frequently than the other, produces substantive results with which we agree. We might well prefer such a theory, but we could regard it as demonstrably better than alternative views only on the basis of the criterion by which all theories are judged: the ability satisfactorily to account for a range of phenomena. Thus, when we say that the value of a theory concerning the Court rests on its application to particular decisions, what we mean is that successful theories satisfactorily account for results that alternative hypotheses fail to explicate.

Given this criterion, what does Shapiro's view of the Court's function explicate-in first amendment cases-that is not also accounted for by the views of the "modest"? Shapiro argues that the Court's clientele consists of those groups and potential groups in our society that are not represented by other political agencies; ${ }^{14}$ that the Court, like other political agencies, ought to act so as to create and support that clientele; ${ }^{15}$ that groups seeking to protect speech are normally not represented by agencies other than the Court; and, hence, that the Court ought to grant protection of their interests a high priority. ${ }^{16}$ Shapiro's view thus accounts for the phenomenon of the Court's affording a special status to first amendment guarantees.

But the fact is that both Hand and Wechsler also account for this phenomenon. Wechsler accepts the "preferred position" conception of first amendment rights "insofar as it recognizes that some ordering of social values is essential; that all cannot be given equal weight, if the Bill of Rights is to be maintained." ${ }^{\text {An }}$ And Hand concludes his Holmes Lectures by "considering [in connection with the first amendment] whether, even assuming that I am right in thinking that the Constitution does not warrant the courts in annulling any legislation because they disapprove it on the

13. Id. at 44 .

I4. See id. at 34-38.

15. See id. at 2,38-39.

I6. See id. at III-15.

I7. H. WECFSLER, supre note 8, at 35. 
merits, nevertheless it is desirable that they should exercise such an authority on extreme occasions." 18

Wechsler's and Hand's acceptance of a special status for first amendment guarantees does not, however, imply that their decision in any given case would accord with that arrived at by Shapiro. A great many value judgments other than that concerning the propriety of judicial review are involved in any given case. Consequently, even a regularly divergent pattern of results might be accounted for-to choose only the most obvious of a spectrum of possibilities-by different weights being assigned to one or more of the other values involved in the decisions. Once the "modest" and Shapiro reach agreement on the existence of a special status for first amendment guarantees, therefore, the verdict on the superiority of Shapiro's view of the proper role of the Court must be "not proven."

Phenomena for which the "modest" cannot account, however, are not difficult to come by. Both Wechsler ${ }^{10}$ and Hand ${ }^{20}$ made clear their inability to construct doctrinal substantiation for the Segregation Cases, ${ }^{21}$ and similar claims of illegitimacy have recently been made ${ }^{22}$ concerning the Reapportionment Cases. ${ }^{23}$ These two sets of cases, moreover, represent the most controversial recent examples of the Court's implementation of policy preferences-of, in the language of the "modest," "political" action. This fact alone, putting aside problems of demonstrating the superiority of Shapiro's theory, would seem a sufficient basis for expecting explication of the reapportionment and segregation decisions to be central to his thesis.

Here, then, are the conclusions arrived at by Shapiro on the basis of his analysis of the Reapportionment. Cases:

The Court's failure to grapple with the complex philosophical and theoretical issues that lie behind the notion of constitutional democracy led it away from the delicate and tentative adjustments that our peculiar form of democracy requires and into the formulation of appealing slogans. The "one man, one vote" slogan, in equating the whole of democracy with majority-rule elections represents naive political philosophy, bad political theory, and no political science. It remains that the Reapportionment Cases are, in one important sense, imprudent political action. One of the first rules of politics at any level is that a politician must keep his word. Great tactical advantage may occasionally be gained from breaking promises, but a politician who earns a reputation for breaking promises cannot survive very long. Courts are not immune to this rule. One of the principal tactics of the Supreme

18. I. HAND, supra note 7, at 56.

19. See H. WECHSLER, supra note 8, at 36-48.

20. See L. Hand, supra note 7 , at 54-55.

2I. Brown v. Board of Educ., 347 U.S. 483 (I954); Barrows v. Jackson, 346 U.S. 249 (I953);

Shelley v. Kraemer, 334 U.S. I (r948); Smith v. Allwright, 32 I U.S. 649 (1944).

22. See, e.g., Neal, Baker v. Carr: Politics in Search of Law, 1962 S. Cr. REv. 252.

23. Reynolds v. Sims, 377 U.S. 533 (1964); WMCA, Inc. v. Lomenzo, 377 U.S. 633 (1964); Maryland Comm. for Fair Representation v. Tawes, 377 U.S. 656 (I964); Davis v. Manm, 377 U.S. 678 (1964); Roman v. Sincock, 377 U.S. 695 (1964); Lucas v. Forty-Fourth Gen. Assembly, 377 U.S. $7 \times 3$ (I964). 
Court's opponents has always been to seize upon a narrowly circumscribed opinion, to inflate it to its logical extreme, and then to attack the extreme rather than the actual opinion. Defenders of the Court have traditionally replied by pointing to the limited nature of the opinions and by insisting that the Court really means only what it says and nothing more. The Court, in its two most important postwar decisions, has obviously meant more than it said, and its subsequent actions have justified those who attacked the most extreme interpretation of its decisions. The Court has, in a sense, not kept its word to those of its defenders who have relied on the initially limited arguments.

The opinion in the school segregation cases was strictly limited to education and rested upon a rationale narrowly drawn to cover only public education. Yet we learned from the subsequent per curiam opinions that, at the time the school cases were decided, the Court had already made up its mind that segregation, not only in schools but also in all public facilities, was unconstitutional.

In Baker v. Carr, the Court said, as far as the jurisdictional niceties would allow, that patently unreasonable districting was unconstitutional, but it carefully avoided the "one man, one vote" rule and hinted strongly in other directions. . . . [T] he Reapportionment Cases made it perfectly clear that what the Court had really meant, although it had not said so, in Baker was that "one man, one vote" is the universal rule applicable to both upper and lower houses of the state legislatures.

The advantage to the Court of such an approach in both the segregation and apportionment cases is obvious. The first and greatest battle rages around the relatively narrow and therefore most easily defended opinion. Then, when the shouting has died down somewhat and the position is solidified by widespread public acceptance, the Court goes on to what it really intended all along, the broadest and most extreme application of its initial decision. Such tactics are politically clever, but they may be too clever. It will hardly be possible in the immediate future to defend any Supreme Court position by pointing to its limited scope. Attackers of the Court will be perfectly safe in painting the most wildly exaggerated pictures of the Court's intentions in any field it enters. It remains to be seen whether or not the tactical advantage gained by its "delayed action" approach will compensate for the Court's loss of that precious political asset, a reputation for candor. ${ }^{24}$

The verdict on the comparative utility of Shapiro's approach to judicial review must once again be "not proven." Here too Shapiro and the "modest" are in agreement. Of course, convergence of Shapiro's and the "modest" assessment of these particular results, no less than divergences, might well be accounted for by policy preferences having nothing to do with judicial review. In fact, Shapiro seems to share with many of those he denominates "modest" a policy preference for the result reached in the Segregation Cases and against that arrived at in the Reapportionment Cases.

The real importance of the quoted passage is the tone and sweep of the condemnation of the Court's works. Indeed, if neither the segregation nor the reapportionment decisions can satisfactorily be accounted for in terms of Shapiro's theory, what have the "modest" to fear from it? True, Shapiro substitutes the charge of imprudent political action for Wechsler's accusa-

24. M. Shupiro, supra note 1 , at 250-52. 
tion of unprincipled-and therefore illegitimate-behavior. But that exchange can represent progress only for those who, on aesthetic grounds, prefer the dull click of value-free social science to the sonorous moralism of the law. The crucial fact remains that Shapiro characterizes as dangerously improper both the reapportionment and segregation decisions. If this be the music of political jurisprudence, the "modest" ought to urge Shapiro to play on.

What makes this coalescence of Shapiro and the "modest" startling is, of course, the wide divergence in their starting points. Shapiro postulates the Court as a political agency competing with other political agencies. The "modest" postulate a need for the Court to avoid opposing political agencies on political matters. Yet Shapiro converges with the "modest" in disavowing two sets of "political" decisions. Unraveling the paradox exemplified by that coalescence constitutes the task of the remainder of this Article.

\section{II.}

Our inquiry begins with Justice Black, whose "activist" first amendment philosophy, approved by Shapiro, ${ }^{25}$ constitutes the unnamed target of many of the "modest" strictures. ${ }^{28}$ Our goal, the assessment of theories concerning the proper role of the Court, requires a focus upon cases in which the issue of the Court's relationship with other governmental agencies is squarely faced-in short, "lawyer's law."

During the Ig62 term Black joined in two decisions that significantly altered the relationship between federal and state courts in criminal cases: Townsend $v$. Sain ${ }^{27}$ delineated a series of standards substantially expanding the circumstances in which federal review of state convictions could take place in habeas corpus proceedings; Fay $v$. Noi $a^{28}$ held inapplicable to habeas corpus the doctrine that an adequate and independent state ground of decision would bar federal review.

Two terms later the Court rendered its decision in Henry v. Missis$\operatorname{sip} p i^{20}$ in which Mississippi argued that the proceedings under attack were insulated from Supreme Court review by the existence of an adequate and independent state ground. Since Henry was seeking direct review of his conviction in the Supreme Court, rather than attempting a collateral attack in a federal district court by means of habeas corpus, Mississippi could—and did-rely directly on Murdock v. Memphis, ${ }^{30}$ which had derived the ade-

25. See M. Shapiro, supra note II, at I08-xi.

26. See, e.g., L. HAND, stipra note 7 , at 77 (penultimate sentence); $c f$. A. Brckex, stipra note 5, at $85-86$.

27. 372 U.S. 293 (1963).

28. 372 U.S. $39 \mathrm{r}(1963)$.

29. 379 U.S. 443 (1965).

30. 87 U.S. ( 20 Wall.) $590(x 875)$. 
quate-state-ground doctrine from a construction of the statute governing direct review of state cases by the Supreme Court, ${ }^{31}$ and which Fay v. Noia had carefully confined to cases involving direct review. ${ }^{\mathbf{3 2}}$

The Court in Henry noted that, given Noia, the existence of an adequate state ground would not suffice to bar federal review in collateral proceedings, ${ }^{33}$ and it also indicated some doubts as to the adequacy of the state ground..$^{34}$ But the Court did not dismiss the case outright, which would have "remanded" Henry to whatever remedies he could obtain in a subsequent federal habeas proceeding. Nor did it find the state ground inadequate and proceed to review the state conviction on the merits. What the Court did was to remand the case to the state courts for a hearing on evidence not included in the record-evidence that the Court regarded as essential to a determination of the adequacy of the state ground. ${ }^{35}$ In support of this remand procedure, the Court relied on its earlier decision in Jackson v. Denno. ${ }^{3 e}$ There, after finding New York's procedure for determining the voluntariness of challenged confessions constitutionally defective, it had remanded the case to the state courts for a hearing restricted to the issue of voluntariness.

Perhaps the most surprising aspect of the Henry decision (besides the fact that neither of the two dissenting opinions raised the issue ${ }^{37}$ ) was its undercutting of the rationale of Townsend v. Sain. Townsend rested on a recognition of the overriding importance of providing a federal forum for determination of the facts underlying a claim of unconstitutional state detention. And a federal forum was precisely what Henry was deprived of by the Court's remand to the state, rather than the federal, judicial system.

The departure, moreover, was far from unintentional. It represented, rather, a conscious attempt to harmonize relations between state and federal courts so as to promote the efficient administration of criminal justice:

By permitting the Mississippi courts to make an initial determination of waiver, we serve the causes of efficient administration of criminal justice, and of harmonious federal-state judicial relations. Such a disposition may make unnecessary the processing of the case through federal courts already laboring under congested dockets, or it may make unnecessary the relitigation in a federal forum of certain issues. . . . The Court is not blind to the fact that the federal habeas corpus juris-

3I. Act of Feb. 5, 1867, ch. 28, § 2, 14 Stat. 385, as amended, 28 U.S.C. $\$ \times 257$ (I964).

32. Sce 372 U.S. at $426-35$.

33. See 379 U.S. at 452 .

34. See id. at $448-49$.

35. Id. at 452 .

36. 378 U.S. 368 (1964).

37. Justice Harlan, joined by Justices Clark and Stewart, dissented, 379 U.S. at 457 , in an opinion stressing the adequacy of the state ground, $i d$. at 458-63, and warning that the decision in Henry presaged substantial erosion of the adequate-state-ground doctrine even in direct-review proceedings, id. at $463-65$. The other dissenting opinion was by Justice Black. Id. at 453 . 
diction has been a source of irritation between the federal and state judiciaries. It has been suggested that this friction might be ameliorated if the States would look upon our decisions in [Fay v. Noia and Townsend v. Sain] . . . as affording them an opportunity to provide state procedures, direct or collateral, for a full airing of federal claims. That prospect is better served by a remand than by relegating petitioner to his federal habeas remedy. ${ }^{38}$

Although Shapiro does not canvass these decisions, they provide considerable support for his view of the Court as a political agency, whose decisions reflect the need to accommodate rival govermental agencies-in this case, the state courts. Henry, on this view, is explained by the fact that federal judicial resources are too exiguous to implement the comprehensive supervision of state criminal proceedings portended by Fay $v$. Noia and Townsend v. Sain. Having recognized this fact, the Court would thus be led by considerations of efficiency as well as harmony to attempt to enlist the aid of state judicial resources. ${ }^{39}$

Justice Black dissented from the remand procedure in Henry as he had in Jackson v. Denno. In both cases, the objection was to "piecemeal prosecution," which was characterized as "unjust" and in violation of "the spirit of the constitutional protection against double jeopardy." ${ }^{\prime \prime 0}$ As indicated in Jackson v. Denno, where he bitterly dissented from the Court's invalidation of a procedure in which the jury alone could resolve evidentiary disputes concerning the voluntariness of a confession, Black's reluctance to sanction remand procedures involving hearings before judges draws heavily upon his conviction that juries are to be preferred as factfinding bodies: "[T] he Constitution itself long ago made the decision that juries are to be trusted."

Yet Black joined the decision in Townsend v. Sain, which considerably expanded the number of cases in which federal judges sitting without juries in habeas corpus proceedings will be obliged to review findings of fact embodied in the verdicts of state juries. And in Jackson v. Denno itself Black indicated:

It is our duty when a conviction for crime comes to us based in part on a confession to review the record to decide for ourselves whether that confession was freely and

38. Id. at $452-53$ (footnotes omitted).

39. Shapiro's view of the Court's role also contributes to an analysis of the decision in Fay $\boldsymbol{v}$. Noia. The obvious alternative to the decision arrived at in that case would have been a holding that reliance by the state upon the procedural default there at issue to bar reexamination of a conviction based on an admittedly coerced confession ran afoul of federal due process standards. Such a holding, however, would have resulted in a substantial increase in the Court's workload. Any reliance by the state upon a procedural default would have been open to a due process attack on direct review, and the Court would have been forced to develop viable standards on a case-by-case basis. In effect, the decision in Fay $v$. Noia can be seen as a shifting of this potential workload-as well as the substantive issues that have to be considered once reliance on the procedural default is held to be unavailing - to the lower federal courts. The decision in Henry can be viewed as an attempt to shift the burden yet further - to the state courts. Considerations of workload were explicitly canvassed in Murdock v. Memphis. See 87 U.S. (20 Wall.) at 628-29.

40. 378 U.S. at 4 I0; accord, 379 U.S. at $454-55$.

4I. 378 U.S. at 405 . 
voluntarily given. In so doing we must reexamine the facts to be certain that there has been no constitutional violation, and our inquiry to determine the facts on which constitutional rights depend cannot be cut off by factfindings at the trial, whether by judge or by jury. ${ }^{42}$

Are these positions of Black's reconcilable? By what warrant does the Court, implementing constitutional guarantees, override the factual determination arrived at by a jury, if that very Constitution grants to the jury a preferred status as a factfinder?

The answer, phrased in terms of a contrast between judges rendering constitutional decisions and those making nonconstitutional law, rather than between judges and juries, is to be found in Linkletter $v$. Walker. ${ }^{43}$ There the Court refused to make retroactive the holding in Mapp v. Ohio, which had held that illegally seized evidence was inadmissible in state criminal proceedings. The reasoning of Linkletter was that (I) retroactivity would have no deterrent effect on police conduct (since the evidence in question had already been seized) and (2) a holding of retroactivity (due to the need for new hearings on the admissibility of evidence long since forgotten, destroyed, or deteriorated) "would tax the administration of justice to the utmost." ${ }^{\text {"5 }}$ Dissenting, Black noted:

In making this ruling the Court assumes for itself the virtue of acting in harmony with a comment of Justice Holmes that " $t]$ he life of the law has not been logic: it has been experience." Justice Holmes was not there talking about the Constitution; he was talking about the evolving judge-made law of England and of some of our States whose judges are allowed to follow in the common law tradition. ${ }^{46}$

This discounting of the factor of experience in constitutional adjudication accounts for Black's willingness to override jury determinations where constitutional rights are at stake. It need only be recalled that it is precisely the factor of experience-of greater familiarity with contemporary community views and standards-that juries bring to the adjudicatory process. Black's association of the process of constitutional adjudication with the rigor of logic rather than the flexibility of experience is, moreover, wholly consonant with the fact of his dissent from the "political" decision in Henry. Thus, while the Henry dissent is based, substantively, on the inadequacy of the state ground there at issue, ${ }^{47}$ the Linkletter dissent strongly suggests that even in the absence of such substantive factors Black would in many instances find political jurisprudence, with its emphasis on flexible accom-

42. Id. at 408 .

43. 381 U.S. 618 (1965).

44. 367 U.S. 643 (196r).

45. 381 U.S. at 637 .

46. Id. at 642 . For an analogous attempt by Justice Black to set limits on the discretion of the Court to give less than full retroactive effect to its decisions, in this instance in the interpretation of statutes defining criminal conduct, see James v. United States, 366 U.S. 213, 222 (I961).

47. See 379 U.S. at $455-57$. 
modations among rival agencies, incompatible with the rigorous demands of constitutional "logic."

We must defer further exploration of the issues raised by Black's contrast between common-law development and the processes of constitutional adjudication until part VI of this Article. What is important for present purposes is that Black's logic-experience dichotomy can be derived directly from his insistence on constitutional "absolutes." As demonstrated by Professor Reich's concise delineation of the connection between "absolutes" and Black's opposition to the "balancing" approach long utilized by the Court in first amendment and due process cases, Black sees an emphasis on "experience" as underlying the constitutional "balances" he so strongly disapproves:

[T] The Court's ad hoc balances are on a "slippery slope." Each is likely to reflect present-day needs and views. Each has for a standard its predecessor, and by degrees what is thought shocking to the conscience or necessary to the maintenance of democratic society may become far different from what was first conceived. The urgencies of the day, like gravity, pull the Court along; there is no counterweight in its formula to maintain a constant level.

The notion of "absolutes" can best be seen, then, as an answer to a process of judging which Black believes to be out of keeping with the Constitution. It developed as a dissenting position. It represents a plea for constitutional adjudication with definite standards. ${ }^{48}$

Black's insistence on "absolutes" served as the focal point for the "modest" attack on his views. ${ }^{49}$ Yet that insistence eventuates in a call for definite standards in constitutional adjudication that strangely echoes Wechsler's demand for neutral principles. Delineation of the differences between the views of Black and those of the "modest" thus hinges on an analysis of the neutrality of neutral principles, an issue to which we must now turn. ${ }^{50}$

\section{III.}

The problem to which Wechsler's essay is devoted is posed by him in the following terms: The Segregation Cases (Wechsler analyzes in detail those involving white primaries, restrictive covenants, and segregated schools) "have the best chance of making an enduring contribution to the quality of our society of any that I know in recent years." ${ }^{\text {"51 }}$ Yet Wechsler cannot approve those decisions because they do not "rest on neutral prin-

48. Reich, Mr. Justice Black and the Living Constitution, 76 Harv. L. Rev. 673, 743-44 (x963). 49. See authorities cited note 26 supra.

50. A bibliography of the considerable literature spawned by the neutral-principles controversy can be found in M. SHAPIRO, supra note $\mathrm{I}$, at I 7 n.37.

5I. H. WECHSLER, supra note 8, at 37 . 
ciples" and hence are not "entitled to approval in the only terms that I acknowledge to be relevant to a decision of the courts." ${ }^{92}$

A.

Wechsler derives the postulate that judicial decisions are legitimate only when they rest on neutral principles from the duty of constitutional adjudication that he finds article III to impose on the courts:

The courts have both the title and the duty when a case is properly before them to review the actions of the other branches in the light of constitutional provisions, even though the action involves value choices, as invariably action does. In doing so, however, they are bound to function otherwise than as a naked power organ; they participate as courts of law. This calls for facing how determinations of this kind can be asserted to have any legal quality. The answer, I suggest, inheres primarily in that they are-or are obliged to be-entirely principled. A principled decision, in the sense I have in mind, is one that rests on reasons with respect to all the issues in the case, reasons that in their generality and their neutrality transcend any immediate result that is involved. When no sufficient reasons of this kind can be assigned for overturning value choices of the other branches of the Government or of a state, those choices must, of course, survive. Otherwise, as Holmes said in his first opinion for the Court, "a constitution, instead of embodying only relatively fundamental rules of right, as generally understood by all English-speaking communities, would become the partisan of a particular set of ethical or economical opinions . . . ."."53

The central difficulty with this passage is that its core is assertion rather than explanation. It tells us that courts are "bound to function otherwise than as a naked power organ," but it does not tell us why. Wechsler's only approach to explanation of his assertion begins with a catalog of recent Court decisions which, in his view, represent ad hoc rather than principled evaluations: first amendment attacks upon congressional investigations of suspected Communists, which their authors would not feel obliged to press home against investigations of labor racketeers; first amendment objections to the Smith Act, which would not be raised to legislation directed against agitators preaching racial prejudice; attempts to interpret first amendment guarantees so as to void convictions based on advocacy of the abstract doctrine of communism, which would not be forthcoming on behalf of those advocating resistance to court decrees; and enthusiasm for jury trial, which seemingly abates before the prospect of making trial by jury available to white southerners accused of civil rights violations. ${ }^{54}$

The constitutional positions described by Wechsler are, of course, those espoused by Justice Black. Wechsler may or may not believe that Black

52. Id.

53. Id. at $27-28$.

54. See id. at 20-2r. 
personally would balk at extending first amendment protections to the fact situations delineated above. What is clear is that Wechsler's conclusion-that the positions taken by Black represent ad hoc responses to particular situations-rests on his belief that application of such guarantees to labor racketeers and racial agitators, for example, represent extensions that are impermissible yet necessarily entailed by Black's positions. Implicit in Wechsler's catalog, in short, is the nub of the "modest" case against the "absolutes" of Black's constitutional philosophy.

Wechsler continues:

All I have said, you may reply, is something no one will deny, that principles are largely instrumental as they are employed in politics, instrumental in relation to results that a controlling sentiment demands at any given time. Politicians recognize this fact of life and are obliged to trim and shape their speech and votes accordingly, unless perchance they are prepared to step aside; and the example that John Quincy Adams set somehow is rarely followed.

That is, indeed, all I have said but I now add that whether you are tolerant, perhaps more tolerant than I, of the ad hoc in politics, with principle reduced to a manipulative tool, are you not also ready to agree that something else is called for from the courts? I put it to you that the main constituent of the judicial process is precisely that it must be genuinely principled, resting with respect to every step that is involved in reaching judgment on analysis and reasons quite transcending the immediate result that is achieved. To be sure, the courts decide, or should decide, only the case they have before them. But must they not decide on grounds of adequate neutrality and generality, tested not only by the instant application but by others that the principles imply? Is it not the very essence of judicial method to insist upon attending to such other cases, preferably those involving an opposing interest, in evaluating any principle avowed? ${ }^{55}$

The need for neutral principles is thus derived by Wechsler from the contrast between the ad hoc ways of politics and the principled processes of the courts. This derivation, however, is crucially flawed, at least in part because of Wechsler's use of rhetorical questions to explicate a concept central to his scheme. The most striking difficulty involves Wechsler's assuming the conclusion that he purports to derive. Wechsler begins by asserting that the branches of government whose actions the Court reviews act as "naked power organs" in arriving at ad hoc decisions. The question he puts is why the Court may not legitimately utilize similar processes in constitutional adjudication. His response is that principled adjudication is the "main constituent of the judicial process." But this response is relevant only on the assumption that the process of constitutional adjudication is in fact a judicial process: only, in other words, if Wechsler assumes that the Supreme Court-in the exercise of its constitutional functions-is acting as a court rather than as a "naked power organ." 
By deriving the judicial need for neutral principles entirely from a contrast with the ad hoc decisionmaking processes of the "political" branches, Wechsler also seriously undercuts his attack on Black's "absolutes." The extensions of Black's positions drawn by Wechsler are regarded by him as impermissible wholly on prudential grounds. There is nothing in the nature of labor racketeers or racial agitators, for example, that leads Wechsler to desire to protect them as such. Quite the contrary, Wechsler must hold that the situations he sketches are ones in which courts ought to deny any protection allegedly afforded by constitutional guarantees. Otherwise, if Wechsler believed that courts ought to protect civil rights violators and persons who advocate resistance to court decrees-if, in other words, Wechsler held that the first amendment covered such situations-his charge that Black's positions are ad hoc could not be maintained.

Wechsler's point, then, is that the constitutional protection afforded by Black to Negroes and Communists, whom we do wish to protect, makes it impossible to deny those protections to such as labor racketeers and racial agitators, whom we ought not to protect. Given his contrast between wholly ad hoc political branches and a wholly principled judiciary, however, that objection-based, as it is, wholly on prudential grounds-seems one more properly addressed to a legislature than a court.

There is, of course, the alternative of not enforcing the relevant constitutional guarantee in either situation, and it seems significant that the only example of an adequately neutral principle given by Wechsler is the Court's abandonment of any attempt to place limitations upon congressional exercise of the commerce and taxing powers-a retreat so complete that Wechsler is led to speculate on the possibility of principles entailing less comprehensive abdications. ${ }^{56}$ This speculation, like the opening section of the essay in which Wechsler derives a justification for judicial review from a reading of the constitutional text, reassures us that there must indeed exist constitutional checks that the Court was intended to impose upon the acts of the political branches.

Once the existence of such limits is admitted, however, the question arises how they are to be enforced. And it is precisely Wechsler's contrast with the prudential, ad hoc nature of political decisions that suggests that judicial enforcement ought to be across the board, to the utmost logical limits of the principle enunciated, untroubled by those prudential con-

56. Sec id. at 32-33.

Another possible interpretation of Wechsler's catalog is that it is intended to assert only that the first amendment principles enunciated by Black are ad hoc without asserting that no neutral principle could be developed capable of distinguishing between, for example, Negroes and racial agitators. But the views embodied in Wechsler's catalog are not specifically attributed to Black; what Wechsler implies about the necessity of according to racial agitators the same measure of first amendment protections granted to Negroes must therefore be read as referring to the entire spectrum of possible first amendment interpretations, not just those espoused by Black. 
siderations that the contrast relegates to the sphere of politics. Thus if Wechsler's universe contains constitutional guarantees judicially enforceable otherwise than by abdication, the very contrast on the basis of which neutral principles were found necessary mandates that those guarantees take the form of Justice Black's "absolutes."

The final difficulty with deriving the need for neutral principles from a contrast between ad hoc political decisions and principled judicial processes goes to the heart of the contrast itself. Far from describing reality, that contrast, like the use of rhetorical questions, is ultimately no more than a literary device. Wechsler himself believes that a society governed by political institutions whose decisions were always and entirely unprincipled could not long survive; his catalog of contemporary ad hoc judicial decisions is preceded by an historical survey of constitutional positions taken by a President $t^{57}$ and in Congress ${ }^{58}$ - positions he deems unprincipled. And the implied judgment is not an approving one.

Unfortunately, this commendable recognition of an obligation to principle on the part of the political branches dissolves the very contrast from which Wechsler derives the judicial need for neutral principles. Once it is admitted that political decisions are only sometimes or partially ad hoc, the literary device of a contrast can no longer serve to justify the demand that constitutional adjudications be always and absolutely principled. Yet that is precisely the demand that Wechsler makes.

B.

The contrast from which Wechsler derives a need for neutral principles thus does not aid in answering the very question with which Wechsler began: Why is it illegitimate for the Court, in the exercise of its constitutional functions, to act (at least partially or sometimes) as a "naked power organ"? Wechsler adverts to the contrast between power organs and courts of law almost immediately after setting out his justification for judicial review, at a juncture in his argument preceding the introduction of the concept of neutral principles: ${ }^{59}$

57. See id. at I8: "Was not Jefferson in the Iouisiana Purchase forced to rest on an expansive reading of the clauses granting national authority of the very kind that he had steadfastly opposed in his attacks upon the Bank?"

58. See id. at 17-18: "Did not New England challenge the embargo that the South supported on the very ground on which the South was to resist New England's demand for a protective tariff?"

59. The problem to which Wechsler is responding at this point is that " $[t]$ hose who perceive in law only the element of fiat, in whose conception of the legal cosmos reason has no meaning or no place, will not join gladly in the search for [criteria that can be framed and tested as an exercise of reason and not merely as an act of willfulness or will] ...." Id. at I6. Once again, Wechsler has structured an issue encompassing an entire spectrum of possible interactions, this time of reason and will, so as to create a single antithesis. But we need not explore the similarities between this formulation and the contrast between ad hoc politics and principled adjudication, since Wechsler immediately disclaims any intention to "try to overcome the philosophic doubt" raised by the possibility of perceiving law as fiat, since "[ $t]$ hat battle must be fought on wider fronts than that of constitutional interpretation." Id. at $\mathrm{r} 7$. 
The man who simply lets his judgment turn on the immediate result may not, however, realize that his position implies that the courts are free to function as a naked power organ, that it is an empty affirmation to regard them, as ambivalently he so often does, as courts of law. If he may know he disapproves of a decision when all he knows is that it has sustained a claim put forward by a labor union or a taxpayer, a Negro or a segregationist, a corporation or a Communist-he acquiesces in the proposition that a man of different sympathy but equal information may no less properly conclude that he approves. ${ }^{60}$

The Court may not act as a power organ, then, because to do so entails the possibility that persons who disagree with its results might on that basis legitimately object to its decisions. The legitimacy of opposition to executive and legislative decisions based on disagreement with the results reached is, for Wechsler, a necessary concomitant of their status as power organs. If the political branches can survive this state of affairs, however, why does Wechsler assume that the courts could not?

One possible answer is to be found in the reasoning that underlay Hand's position on judicial review. If constitutional adjudication is viewed as an anomaly in a democratic society, as a process in which a politically irresponsible institution reviews the acts of duly elected legislative and executive officials, then of course the Court's constitutional decisions require a species of justification wholly different from that demanded of elected institutions. That this reasoning both provides the basis for the contrast between courts of law and power organs and defines the need for neutral principles emerges from a reading of the passages immediately following the contrast between ad hoc political institutions and principled courts.

Wechsler begins by granting, as "commonplace," "that courts in constitutional determinations face issues that are inescapably 'political' . . . in that they involve a choice among competing values or desires, a choice reflected in the legislative or executive action in question, which the court must either condemn or condone." ${ }^{61}$ The argument continues:

But what is crucial, I submit, is not the nature of the question but the nature of the answer that may validly be given by the courts. No legislature or executive is obligated by the nature of its function to support its choice of values by the type of reasoned explanation that I have suggested is intrinsic to judicial action-however much we may admire such a reasoned explanation when we find it in those other realms.

Does not the special duty of the courts to judge by neutral principles addressed to all the issues make it inapposite to contend, as Judge Hand does, that no court can review the legislative choice-by any standard other than a fixed, "historical meaning" of constitutional provisions-without becoming "a third legislative chamber"? Is there not, in short, a vital difference between legislative freedom to 
appraise the gains and losses in projected measures and the kind of principled ap praisal, in respect of values that can reasonably be asserted to have constitutional dimension, that alone is in the province of the courts? Does not the difference yield a middle ground between a judicial House of Lords and the abandonment of any limitation on the other branches-a middle ground consisting of judicial action that embodies what are surely the main qualities of law, its generality and its neutrality? ${ }^{\text {?2 }}$

Two factors, in addition to the textual evidence, further suggest that, in Wechsler's scheme, the function of neutral principles is to meet the difficulties posed by Hand. First, this interpretation provides the basis for a meaningful statement concerning constitutional adjudication: Because the Court, as an undemocratic institution, represents an anomaly in our democratic society, its decisions require a higher degree of justification than that demanded of the legislature or executive, a degree of justification embodied in the demand for total neutrality. The alternative, as we have seen, is to reduce neutral principles to a formulation that assumes the answer it seeks to demonstrate.

Second, to view neutral principles as a response to Hand's dilemma concerning the undemocratic nature of judicial review serves to explain Wechsler's objection to Black's "absolutes." If judicial review represents an exception to democratic norms that otherwise govern our polity, then, in Wechsler's words, "the courts ought to be cautious to impose a choice of values on the other branches or a state, based upon the Constitution, only when they are persuaded, on an adequate and principled analysis, that the choice is clear." ${ }^{\text {"63 }}$ Given Hand's assumption, it is manifest that the Court cannot justifiably push a constitutional principle to logical extremes; an undemocratic Court must be a cautious Court, and a cautious Court eschews "absolutes."

There is a difficulty, however, with the interpretation of neutral principles delineated above. It postulates that the need for neutral principles is rooted not-as Wechsler has it-in the nature of the judicial process, but rather in the undemocratic nature of the Court. On this interpretation, the contrast from which neutral principles are derived is between democratic political branches and an undemocratic Court, not between ad hoc politics and principled adjudication. To be sure, it is presumably the democratic nature of the political branches that, in Wechsler's view, legitimizes their resort to ad hoc decisions. If, however, the crucial fact in the analysis is not that the legislature is ad hoc, but rather that it is democratic, the corresponding directive to the Court must prescribe not principle, but caution.

If this interpretation of neutral principles is to be acceptable, therefore,

62. Id. at 22-23.

63. Id. at 34 . 
it must account for the fact that Wechsler focused on the ad hoc rather than the democratic aspect of the political process. Except in his series of rhetorical questions, Wechsler never adverts to Hand's argument. If the concept of neutral principles was intended to respond to Hand's dilemma, why did that dilemma go unacknowledged?

The answer is that Wechsler had already established the legitimacy of judicial review by means of his gloss on article III. Having thus duly exorcised the spectre of judicial usurpation, no warrant existed for the invocation of yet another remedy. Participation in duly prescribed rites for the warding off of harm does not, however, prevent resort to amulets; it only makes the wearer reluctant to reveal the identity of the evil against which the charm offers protection.

\section{C.}

Even amulets have their uses, of course, if the danger be sufficiently serious. Putting aside Wechsler's reading of the constitutional text, we must, therefore, confront the question of whether the status of judicial review in our society is so anomalous as to justify a demand for total adherence to neutral principles.

The attempt to derive a need for such adherence from the contrast between an undemocratic Court and democratic political branches ultimately suffers from precisely the same defect that marred the earlier contrast between ad hoc politics and principled adjudication. Even superficial analysis reveals, as in the earlier instance, that the contrast between a Court wholly insulated from the desires of the electorate and a legislature and executive devotedly registering the will of their constituents functions rather as a literary device than as a description of reality.

To begin with the political branches, is it at all accurate to describe Senator Fulbright as having represented, over the years, the views of his constituency on international affairs? It might be argued that he has carefully reflected those views on other issues deemed more important by that constituency, but then what of his control over the Senate Committee on Foreign Relations? Insofar as control over that committee's affairs carries with it the power to influence governmental decisions, Fulbright has been exercising irresponsible power. Similarly, Congressman Mills' very considerable power as chairman of the House Committee on Ways and Means is derived not from the importance of his constituency, but rather from the central role accorded to committees in the legislative process. And power exercised by administrative agencies is, of course, even further removed from any direct accountability to the electorate. Shapiro's conclusion, after a survey of the actual workings of the political system, ${ }^{64}$ is as follows: 
[T] he lawmaker, whom the modest so reverently endow with democracy's banner, is none other than precisely this combination of bureaucracy, President, and Congress, for, quite obviously, all three are major participants in the shaping of our laws. In short, the lawmaker to whom the nasty old undemocratic Supreme Court is supposed to yield so reverently because of his greater democratic virtues is the entire mass of majoritarian-anti-majoritarian, elected-appointed, special interestgeneral interest, responsible-irresponsible elements that make up American national politics. If we are off on a democratic quest, the dragon begins to look better and better and St. George worse and worse. ${ }^{95}$

The other side of the coin-the political irresponsibility of the Courtis similarly far more complicated than the antithetical nature of the contrast might suggest. The ultimate weapons that Congress and the President can bring to bear on the Court are analogous to those they use to influence the decisions of the "independent" administrative agencies: control over appropriations and a refusal to execute decisions. And the Court is certainly not unique among nonelected governmental agencies in having developed sufficient resources of its own to make either a cut in appropriations or an executive refusal to enforce its decisions highly unlikely. Similarly, Professor Dahl has demonstrated the considerable power available to the President to shape the policies of the Court through the appointment process, ${ }^{66}$ a degree of "electoral" control analogous to that which is exercised over the "independent" administrative agencies. Indeed, given the relatively fast turnover of Justices revealed by Dahl's statistics, and the development, in connection with several agencies, of a tradition of reappointment, the statistical correspondence may be a quite precise one.

There is, moreover, a fundamental contradiction inherent in the position that the Court, because it is irresponsible, ought not to make political decisions, ought not, in the words of Holmes quoted by Wechsler, to "become the partisan of a particular set of ethical or economical opinions." This difficulty is apparent in a passage from a recent article describing the process by which power in the United States has tended to centralize in federal institutions:

Sharing in the general euphoria of power, the nine justices of the Supreme Court make major political decisions, unresponsive to the democratic process, in secret meetings on Friday afternoons. Both the number and the scope of such decisions steadily mount. Liberal critics have generally approved this development because they approve the content of the decisions, while the fundamental reshaping of an important institution seems not to trouble them. But it is a transformation which almost certainly will come back to plague us as judicial personnel and social attitudes change, and as an institution which has become more and more political develops an even greater sensitivity to transitory shifts in the political temper. ${ }^{.3}$

65. Id. at 32 .

66. See Dahl, Decision-Making in a Democracy: The Supreme Court as a National Policy-Maker,

6 J. PuB. L. 279, 284-86 (1957).

67. Text accompanying note 53 supra.

68. Goodwin, The Shape of American Politics, Commentary, June 1967, at 26-27. 
The quoted argument, it should be noted, follows Wechsler in intimating no disapproval of the content of the decisions "approved by liberal critics." The point is, rather, that the Court should not have made such decisions at all, and two arguments are offered in support. First, these decisions are political in nature and hence should not be entrusted to an institution "unresponsive to the democratic process." Second, the making of such political decisions involves a fundamental transformation of the institution that "will come back to plague us as ... [the] institution ... develops an [ever] greater sensitivity to transitory shifts in the political temper."

If the difficulty with entrusting political decisions to the Court is its political unresponsiveness, ought we not welcome a "greater sensitivity to ... shifts in the political temper?" If, on the other hand, we distrust decisions based on transitory shifts in the electorate's mood, is not the solution precisely an institution "unresponsive to the democratic process?" What we cannot do-once we agree that judicial review involves a duty to render decisions that necessarily entail political consequences-is to have it both ways, simultaneously denying legitimacy to decisions of a politically unresponsive institution and to decisions of one that responds to shifts in political sentiment.

The above analysis does not deny, of course, that in many areas of governmental concern the political branches are more responsive than the judiciary to the wishes of the electorate. Nor does it deny that, even on issues as to which the Court might possess a special responsiveness, the quality of that responsiveness ought to differ from the deference accorded electoral opinion by the legislature or executive. Nor, finally, does it deny that Court decisions will typically have far more serious consequences than those reached by administrative agencies and that this fact ought to have a considerable bearing on the scope and frequency of the Court's interventions. The point is simply that the antithesis between democratic political branches and an undemocratic Court is not a complete one, and hence that a demand for total neutrality cannot be derived from that contrast.

\section{D.}

On the level of assertion rather than justification, however, Wechsler's demand for neutrality and generality rings true. If the arguments he presents fail to establish the need for total adherence to a concept of neutral principles, his insistence that reasoned opinions have historically been integral to the judicial process nevertheless raises the issue of the role and content of reasoned explanation in constitutional adjudication. Any final assessment of Wechsler's argument hinges upon the resolution of that issue.

The process of reasoned explanation embodies, according to Wechsler, two components, neutrality and generality; but he defines neither the con- 
tent of these component parts nor the interrelationship between them. Much of the criticism directed against Wechsler's argument presupposes that the concept of neutral principles entails a demand for neutral criteria on the basis of which a choice among competing values can be made. ${ }^{68}$ Such a demand ultimately involves a contradiction, since the existence of a neutral criterion, precisely because of its neutrality, eliminates the necessity for choice that Wechsler agrees is "inescapable." On that ground alone the proposed interpretation seems an unlikely one. Moreover, Wechsler's contrast between principled adjudication and ad hoc political decisionmaking strongly suggests, although the distinction is never explicitly drawn, that he was focusing on the process of applying rather than deriving constitutional principles. Presumably on the basis of arguments such as these, Professor Ernest Brown, in a review of Wechsler's work, suggests that the formulation " the neutral application of general principles' . . . would be more explicit of his idea, if less arresting." "1

Such a formulation exposes the fallacious assumption underlying much of the criticism of Wechsler, but its own foundations are none too secure, since it presupposes the existence of constitutional principles whose generality remains unaffected by the process of application. Constitutional adjudication, however, is a process in which the general content of a constitutional principle is only gradually defined by means of its application in a concrete series of cases. Given this process, the neutrality of application of a constitutional principle depends precisely on the degree to which its formulation takes into account those competing principles that, under some circumstances, require a different result; a principle is neutrally applied, in other words, where its nonapplication in circumstances to which it is arguably applicable can be justified by reference to competing principles. ${ }^{72}$

What this formulation makes clear is that the test of "neutral application" is simply another way of stating a test for adequate generality. Thus, a principle is neutrally applied when it is applied to a sufficiently large number of diverse fact situations; but its application to those situations is a function of the degree of generality in its formulation-of the degree to which competing values were taken into account in the derivation of the principle. We may, therefore, reformulate the concept of neutral principles as requiring the general application of general constitutional principles, and define neutrality as the concept in terms of which Wechsler tests the adequacy of generality.

69. See, e.g., Miller \& Howell, The Myth of Neutrality in Constitutional Adjudication, 27 U. Carn. L. REv. 66r (1960); cf. Mueller \& Schwartz, The Principle of Nettral Principles, 7 U.C.L.A.L. Rev. $57 \mathrm{r}(1960)$.

70. See text accompanying note 6r supra.

7I. Brown, Book Review, 62 Colum. L. Rev. 386, 387 (I962).

72. A similar analysis is developed at greater length in Golding, Principled Decision-Making and the Supreme Court, 63 CoLUM. L. Rev. 35 (I963). 
That Professor Brown sees neutrality as no more than a test for the adequacy of the generality with which a constitutional principle is expressed is clear from the defense he offers for the Court's decision in Smith v. Allwright. ${ }^{33}$ In that case, involving primary elections conducted by the Texas Democratic Party, which was treated by state law as a private voluntary association, the Court held attempts to exclude persons from the primaries on the basis of race violative of constitutional guarantees. Wechsler condemns the decision as unprincipled because the principle involved seems to him necessarily to entail the impermissible proposition that political parties could not be organized exclusively on the basis of religious, economic, or social classifications or ideologies. ${ }^{74}$ Brown responds:

Cause and effect are difficult to establish in political institutions, but it is at least a tenable thesis that the system of legally significant primary elections is an outgrowth of a party system in which the major parties, to which primaries signifcantly relate, have historically been amorphous, heterogeneous, and heterodox. In dealing with an institution in what is, I should think, its predominant historical and functional context, it seems questionable that Smith v. Allwright can be considered unprincipled because it did not anticipate possibilities lying in a hypothetical, and different, future. ${ }^{75}$

Significantly, Brown denies neither that the extension postulated by Wechsler is necessarily entailed by the Allwright principle nor that the extension would be impermissible. His point, rather, is that, given the historical context in which the case arose, it was unnecessary for the Court to consider Wechsler's extension in formulating the constitutional principle involved. According to Brown, in short, the Allwright principle was adequately general because the factual situation stressed by Wechsler, in which the principle could not neutrally be applied, was one unlikely to arise in the foreseeable future.

One response to this analysis would deny the legitimacy of relying upon an historical context to set limits on the degree of generality that can be accepted as adequate. Generality is adequate, such a response would run, only when the principle involved can be demonstrated to be applicable neutrally in any conceivable factual situation. Although the phrasing is different, such a response represents simply a reformulation of the demand for totally principled adjudication, a demand that, as we have seen, could not be justified in terms of Wechsler's argument.

The demand for adequately general principles, moreover, is not advanced as part of a theoretical model, but rather as a standard for judging the legitimacy of constitutional decisions. The position that adequacy requires neutral application in any conceivable set of circumstances in fact

73. 321 U.S. 649 (1944).

74. H. WECESLER, supra note 8 , at 39-40.

75. Brown, supra note 7I, at $39 \mathrm{x}$. 
demands that judges decide cases on the basis of a constitutional principle only when that principle forms part of a completely coherent system applicable across the board. Such a total system may in theory be possible, although everything in our experience of constitutional adjudication counsels the contrary. But the crucial point in this context is an empirical one: the practical impossibility of constructing a completely coherent system of constitutional law at any given time. The demand for total generality, like the demand for totally principled adjudication, ${ }^{78}$ thus renders superfluous any defense of judicial review; a Court that could review only after it had constructed a totally coherent system would in practice not review at all.

We need not, in this connection, assess the validity of the particular justification offered by Brown for the Allwright decision. It may be, for example, that only factors other than historical ones may legitimately be used to delimit the generality required of constitutional principles. Similarly, the historical context in which Allwright arose may not be capable of supporting the interpretation Brown seeks to place upon the case. Neither of these possibilities, however, detracts from the insight crucial to Brown's analysis: that adequate generality cannot be synonymous with total generality.

E.

The care with which Wechsler establishes a constitutional justification for judicial review-travail that a demand for total generality would render superfluous-strongly suggests that he would not himself regard the concept of neutral principles as entailing such a demand. Textual arguments aside, however, the issue is one that can best be analyzed in the setting of a concrete case. I choose Brown v. Board of Education ${ }^{77}$ because that case posed most sharply for Wechsler the dilemma that precisely those cases with "the best chance of making an enduring contribution to the quality of our society" had to be disapproved because they did not rest on neutral principles.

The problem that Brown poses for Wechsler is the absence of a neutral principle upon which a choice in favor of integration can be based, "[g]iven a situation where the state must practically choose between denying the association to those individuals who wish it or imposing it on those who would avoid it."78 Since Wechsler agrees that legitimate Court decisions

76. See text accompanying note 56 supra.

77. 347 U.S. 483 (1954).

78. H. WECHSLER, supra note 8 , at 47 . Attempts have been made to deny the propriety of this formulation of the issue posed by Brown. Dean Pollak, for example, argues that the right not to associate is not involved because the forced association results, not from the decision in Brown, but as a consequence of the existence of compulsory school laws, and that children who wished to exercise the right not to associate could in any event do so by attending private schools. Pollak, Racial Discrimination and Judicial lntegrity: A Reply to Professor Wechsler, 108 U. PA. L. REv, I, 29-30 (1959).

The difficulty with this argument is, of course, the financial burden involved in attending private 
"inescapably . . . involve a choice among competing values or desires," why is not a satisfactory justification for Brown simply that, in the concrete situation presented, the right to associate weighed more heavily than that not to associate? There exist, of course, situations more or less analogous in which, as Wechsler indicates, the conclusion would most likely be the opposite, ${ }^{80}$ but that fact does no more than define the problem. Granted the existence of analogous situations in which the values of association and nonassociation would be weighted differently, the question remains why a weighting in favor of association in Brown does not itself constitute a constitutional principle of adequate generality.

Wechsler's answer is that such a decision does not rest on a neutral principle because the "judgment turn[s] on the immediate result." examples he cites, described as uses of impermissible bases for assessing, rather than arriving at, decisions, consist of cases in which claims are approved because they have been "put forward by a labor union or a taxpayer, a Negro or a segregationist, a corporation or a Communist." ${ }^{22}$ Using these examples, we can more precisely define the question at issue: In what sense is a constitutional principle inadequately general if it states that all claims put forward by Negroes or Communists will be approved, or that all claims advanced by segregationists or corporations will be rejected?

One response is that the principle is inadequate because it is incapable of being applied to all cases involving, for example, claims advanced by Negroes. But what does such an assertion mean? If it means simply that the Court, irrespective of other values embodied in different situations, does not intend to approve all claims advanced by Negroes, then the assertion denies, not the adequacy of the principle's generality, but simply the good faith of the Court in enunciating a principle it has no intention of follow-

schools. The Supreme Court has informed us that first amendment freedoms "are available to all, not mercly to those who can pay their own way." Murdock v. Pennsylvania, 319 U.S. I05, III (1943). If a right not to associate exists, therefore, by what warrant are those who wish to exercise it required to shoulder an additional financial burden? Why does the fact of that burden not suffice as a basis on which those who wish not to associate can attack a decision that forces them to choose between free schooling and the exercise of the right not to associate?

An analogous argument, based on the financial burden involved in attendance at a private school in which prayers were permitted, was made by Mr. Justice Stewart in dissenting from the Court's decision in School Dist. v. Schempp, 374 U.S. 203, 308, 312-13 (1963). In the context of the prajer decision, Pollak meets this argument by noting that "[i] $\mathfrak{f}$ as to a particular schoolchild a particular prayerless public school really operates to restrain his religious faith, this surely suggests not that such a religious establishment should be tolerated, but that the child would be constitutionally esempt from compliance with the compulsory school laws." L. Pollak, Foreword: Public Prayers in Pablic Schools, 77 HaRv. L. Rev. 62, 77 (1963).

Would a similar exemption be available for children desiring to exercise the right not to associate? A decision to the contrary would have to rest on the proposition that the free-exercise claim in the prayer case was more compelling than the claim of a right not to associate in Brown. Such a judgment, however, has nothing to do with the compulsory school laws, and represents precisely the sort of weighing of constitutional values that Wechsler finds at the core of Brown.

79. H. WECHSLER, supra note 8, at 22.

80. See id. at 46 .

8I. Id. at $\mathrm{r} 7$.

82. Id. 
ing. A Court that refused to apply an enunciated principle to a fact situation involving no values on the basis of which nonapplication could be justified would be deciding solely on the basis of whim and caprice. Quite possibly, then, it is the good faith of the Court, rather than the adequate generality of the principle, that is being challenged.

The assertion that the principle could not be applied to all cases involving claims raised by Negroes could, however, have a different meaninga meaning that has the virtue of going to the question at issue, that of adequate generality. Thus, the assertion could represent a prediction that the principle will in a concrete case conflict with another principle-for example, the principle that all claims put forward by Communists will be approved in a case in which Negroes and Communists assert conflicting claims. If this is what the assertion means, however, we have come full circle, since the short answer to the dilemma presented by conflicting principles is that the Court's role involves the making of a "choice among competing values or desires." It was precisely Wechsler's assent to the legitimacy of performing that task that gave rise to the inquiry into the legitimacy of the Court's choice of association in Brown.

The circle would be broken, of course, if the assertion meant that the possibility of conflict sufficed to render a principle inadequate. But this is simply to restate the demand for total generality, to postulate that no principle can legitimately be applied unless the Court can demonstrate that it would not in any conceivable situation conflict with any other principle. We have already noted the considerable difficulties presented by such a position, ${ }^{83}$ further exploration of which must be deferred until part VI of this Article. The important point for present purposes is that analysis of the principle that all Negro claims will be approved eventuates only in a reiteration of the flat assertion that adequate generality is equivalent to total generality. If this were indeed Wechsler's position, then, it would be a consistent one, but one based on assertion rather than explanation.

F.

Consistency alone, moreover, is not sufficient to make an argument validly persuasive. An argument is validly persuasive only when its persuasive elements stem from the argument itself, and are not extraneous to it. Wechsler's example, the principle that all Negro claims are to be upheld, is persuasive; there exists general agreement that decisions based on such a principle would be illegitimate. But this illegitimacy has nothing whatsoever to do with Wechsler's concept of adequate generality.

As we have seen, Wechsler's test for adequacy is general applicability; his objection to the principle that all Negro claims should be approved

83. See text accompanying notes 56,76 supra. 
is that it represents "ad hoc evaluation" objection would be met, however, if the Court did in fact approve all Negro claims coming before it-a course of action that would neither change the general agreement as to the principle's illegitimacy nor be approved by Wechsler.

Any principle, moreover, can in theory be applied with complete generality, provided only that the Court is willing to disregard the claims of all competing values. The general agreement as to the illegitimacy of the principle that Negro claims should always be favored does not, however, rest on the prediction that that principle might often be held inapplicable; indeed, the more often it was held applicable, the more illegitimate the Court's course of action would be. That agreement rests, rather, directly on disapproval of the content of the principle: disapproval based on the belief that other values are equally or more important than those embodied in Negro claims.

Failure to take these competing claims into account can, of course, be described as a situation in which the content of the principle is inadequately general. Used in this sense, however, the accusation of lack of generality is no longer the "neutral" one of lack of general applicability, but rather expresses disagreement with the weighting of the values from which the principle was derived. Morover, given Wechsler's view that the principle embodied in Brown has "the best chance of making an enduring contribution to the quality of our society of any that I know in recent years," ${ }^{385}$ it is difficult to perceive the basis on which he would disagree with the weighting of values it embodies.

Nor can a standard of total generality be applied to the content of principles, any more than to their applicability, since the proposition that a principle is adequately general only if it does not involve a conflict among values denies the possibility of the "choice among competing values" that Wechsler agrees is a legitimate part of the Court's task. The short of this matter, then, is that the persuasiveness of Wechsler's examples must stem from factors extraneous to his argument. Analysis of those factors may provide a definition of "neutrality" on the basis of which decisions such as Brown-the results of which Wechsler values so highly-can be justified.

What must be investigated is the basis for the general agreement that the principle that all Negro claims should be approved is illegitimate. One of the defects in the principle, embodied in the word "all," has already been noted: the failure to take any competing value into account. Simply delimiting the principle, however, would not suffice to meet the charge of illegitimacy. Thus, in a suitably limited case, we might well find legiti-

84. H. WECHSLER, supra note 8, at I7.

85. Id. at 37. 
mate the principle that, all other things being equal, the claims of those exercising the right of free speech should be favored. Yet it is precisely Wechsler's point that we would not find legitimate even in a single case the proposition that, all other things being equal, the Court should favor the claims of those who are Negroes.

Nor can the difficulty be met by the analysis that the Constitution protects rights such as free speech but not groups of people such as Negroes; one need not search long for authority to the effect that the Reconstruction amendments were intended to protect the newly freed slaves. Perhaps the best illustration of the inadequacy of such an analysis is provided by Professor Brown's justification for the Allwright result. Wechsler, it will be recalled, asserts that the interpretation of equal protection embodied in Allwright could seriously curtail the exercise of first amendment religious and ideological freedoms. Brown dismisses the relevance of this assertion by stressing that the historical context in which Allwright arose rendered highly unlikely attempts to form ideological and religious political parties. Brown's view of history, in short, leads him to the proposition that only racial categories need be considered in assessing the legitimacy of the Allwright result. But is this different from saying that the Allwright principle was legitimate, despite the fact that it threatened the exercise of hypothetical religious and ideological first amendment rights, because it did protect Negroes from actual discrimination?

The difference, of course, is one of phrasing, and the importance of that difference is underlined by the decision in United States v. Brown, ${ }^{86}$ which struck down as violative of the constitutional prohibition against bills of attainder a statutory provision barring Communist Party members from the executive boards of labor organizations. The heart of the holding was that Congress, in passing the statute, had "exceeded the authority granted it by the Constitution" because

[t] he statute does not set forth a generally applicable rule decreeing that any person who commits certain acts or possesses certain characteristics (acts and characteristics which, in Congress' view, make them likely to initiate political strikes) shall not hold union office, and leave to courts and juries the job of deciding what persons have committed the specified acts or possess the specified characteristics. Instead, it designates in no uncertain terms the persons who possess the feared characteristics and therefore cannot hold union office without incurring criminal liability - members of the Communist Party. ${ }^{87}$

United States v. Brown rests on our society's deep-seated aversion to attaching legal consequences to the fact of group membership vel non, an aversion that is essential in a society as heterogeneous as ours if we are to

86. 38 I U.S. 437 (1965).

87 . Id. at 450 . 
avoid the divisive consequences of distrust of that society on the part of minorities. The difficulties involved in attempting to distinguish United States v. Brown ${ }^{88}$ from the Court's earlier decision in American Communications Association, CIO v. Douds ${ }^{89}$ make clear, however, that stressing the existence of this aversion is a way of stating, rather than resolving, the issue. The fact is that all lawmaking-judicial as well as statutory-must perforce proceed in terms of groupings larger than the single individual. Thus, a legislative act directed against a specific person would clearly constitute a bill of attainder, ${ }^{30}$ and judicial decisions whose principles applied only to the situation then before the Court would represent the acme of ad hoc rather than principled evaluation. Even the category of persons exercising first amendment rights, to return to an earlier example, defines an ascertainable group.

The central difficulty raised by the holding in United States $v$. Brown that Congress' grouping for legal purposes constituted a bill of attainder may, therefore, be generalized. To paraphrase the quotation from Holmes that for Wechsler sets forth the dangers to be avoided by adherence to neutral principles, ${ }^{\text {p1 }}$ one man's "relatively fundamental rules of right" may well be another man's "particular set of ethical or economical opinions." What Brown's Allwright justification contributes to the resolution of that diffculty is the insight that the historical context may well determine the proper classification of a given principle as either a "fundamental right" or a "particular opinion."

Redefining neutrality in terms of that insight, a neutral principle becomes one that is perceived as adequately general in terms of the historical context in which it is applied. The question that such a reformulation raises, however, is this: perceived as adequately general by whom? The answer can be derived from the fact that the illegitimacy of the principle approving all Negro claims was ultimately traced to a deeply held social aversion to the attaching of legal consequences to membership in groups, an aversion that is expressed in the demand that constitutional principles be generally applicable. Adequate generality in a judicial decision-neutrality, if you will-is, therefore, that degree of generality perceived as adequate by the very society that imposes the requirement of adequate generality to begin with-that same public whose agreement that the principle approving all Negro claims is illegitimate serves to make Wechsler's illustrations persuasive.

88. Cf. Dennis v. United States, 384 U.S. 855 (1966).

89. 339 U.S. 382 (1950).

90. United States v. Lovett, 328 U.S. 303 (1946).

9I. See text accompanying note 53 supra.

92. Another illustration is provided by the doubt recently cast upon the historically impeccable proposition that legal consequences can legitimately be attached to the status of citizenship by naturalization rather than birth. See Afroyim v. Rusk, 387 U.S. 253 (I967). 
G.

Shapiro accepts Wechsler's demand for adequately general constitutional principles, which he calls "standards," as a political necessity. He agrees that " $[\mathrm{i}] \mathrm{f}$ the Court is to be successful as a political actor, it must have the authority and public acceptance which the principled, reasoned opinion brings." ${ }^{33} \mathrm{He}$ goes on to note, however, that satisfying popular expectations about the legal process

is not a political body's end but its means. It seeks to satisfy expectations in order to build the prestige necessary to pursue policy goals successfully. A court devoted only to creating the judicial myth and enhancing its own prestige would be simply strutting like a peacock. A court must use its prestige to further whatever longrange goals it has chosen. . . .

The question then becomes one of political strategy. The availability of standards becomes one of the factors in the political equation. In those areas where standards are most readily available and reasonably defensible, the Court enjoys the greatest freedom to act. . . . Where the creation or selection of standards would bring the Court into open collision with a politically powerful opponent or force it to do a patent injustice, then standards may not be the order of the day. ${ }^{9 s}$

What Shapiro's formulation makes clear is the danger that adherence to neutral principles is intended to avoid: loss of the Court's ability to gain public acceptance for its decisions. But if Shapiro agrees that " $[\mathrm{p}]$ olitical institutions survive and prosper to the extent that they satisfy widely held expectations about them," faction of those expectations represents no more than one of the complex of values that the Court must weigh in arriving at a decision. Moreover, if the concern underlying the demand for neutrality is the satisfaction of public expectations, the weight to be accorded to that demand must be determined not only by how strongly some members of the public believe a given principle to be inadequately general, but also by the number and influence of those who share that view-and of those who oppose it.

This last proposition affords a basis for explicating the consequences of Wechsler's disapproval of Brown v. Board of Education. Given the high regard in which he holds the Brown result, it would be anomalous in the extreme for Wechsler to deny legitimacy to that decision if he alone perceived the principle it embodies as inadequately general. But Wechsler's disapproval entails more than the empirical judgment that the Brown principle is widely perceived as inadequately general. Whatever the degree of generality deemed by him to be adequate, and whatever the relationship of that degree to the desirability of the result in a given case-whether, that is,

93. M. Shapiro, supra note $\mathrm{I}$, at 29.

94. Id. at 30-3I.

95. Id. at 29 . 
Wechsler believes that a higher or lower standard of adequacy should be imposed as the desirability of the result increases-his disapproval of Brown embodies the judgment that the damage done to public expectations about the Court by Brown's inadequate generality outweighs the desirability of a result which has "the best chance of making an enduring contribution to the quality of our society of any that I know in recent years."

It follows, from a definition of neutrality as that degree of generality that the public perceives as adequate, that the Court ought always to decide on the basis of the most general principle that can fairly be derived -the principle that will maximize satisfaction of public expectations of neutrality. Given that proposition, the most troublesome Court decisions are those per curiam opinions in which no explanation at all is offered, and hence no generality at all achieved.

It is thus no surprise that Wechsler begins his review of decisions that cannot be justified in terms of neutrality with per curiam decisions in the areas of film censorship and segregation. ${ }^{36}$ Strikingly, however, Shapiro's objection to the segregation decisions also rests upon the Court's per curiam opinions, his objection being that resort to such opinions will result in "the Court's loss of that precious political asset, a reputation for candor."97 Loss of "a reputation for candor," however, is precisely the consequence entailed by judicial failure to respond to the demand for neutral principles. Is the demand for "candor," then, simply an insistence upon neutral principles under another name? If so, the differences between the prudential maxims of political jurisprudence and the strictures of the "modest" seem once again to be those of style rather than substance.

\section{IV.}

At the heart of Wechsler's concept of neutral principles, as we have seen, is the demand for generality of principle. Yet early in his argument Wechsler warns that courts may ask "what the Constitution may require or forbid ... only ... when it is necessary for decision of the case that is at hand"198 - a requirement that severely limits the permissible generality of constitutional principles. Wechsler never attempts to resolve the contradiction between a demand for maximum generality and the requirement that a court decide only the case at hand, but the tension between them

96. See H. WeCHSLER, stipra note 8, at 28-3I.

97. See text accompanying note 24 supra.

98. H. WECHsLER, supra note 8 , at IO; see id. at 21 : "To be sure, the courts decide, or should decide, only the case they have before them." 
forms the core of Professor Alexander Bickel's analysis of the work of the Court in The Least Dangerous Branch. ${ }^{99}$

A.

Bickel, like Wechsler, treats justification of the Brown decision as the ultimate test of his approach. He begins with a basic objection to Brown: that the principle of decision in that case entails the constitutional invalidity of measures such as benevolent quotas, which, like statutes requiring school segregation, involve the state's attaching legal consequences to the fact of race. Like Wechsler, ${ }^{100}$ Bickel believes both that benevolent quotas should not be invalidated by the Court and that the Brown principle, fairly read, is inconsistent with a finding of their validity. ${ }^{101}$ What Bickel does not accept is that these two propositions suffice to render the Brown decision unjustifiable; he rejects Wechsler's view that the Court may invoke only those principles that can also justifiably be applied to all relevantly analogous situations.

"Our democratic system of government," argues Bickel,

exists in [the] tension between principle and expediency, and within it judicial review must play its role. Mr. Wechsler's dilemma is a false one. The constitutional function of the Court is to define values and proclaim principles. But this is not a function to be exercised with respect to some exceedingly few matters, while society is left wholly to its devices of expediency in dealing with the great number of its other concerns. Often, as with the segregation problem and slavery before it, we require principle and expediency at once. The rule of the neutral principles would excise the Court's function of declaring principled goals. More, it would require the Court to validate with overtones of principle most of what the political institutions do merely on grounds of expediency. . . .

The essentially important fact, so often missed, is that the Court wields a threefold power. It may strike down legislation as inconsistent with principle. It may validate, or, in Charles L. Black's better word, "legitimate" legislation as consistent with principle. Or it may do neither. It may do neither, and therein lies the secret of its ability to maintain itself in the tension between principle and expediency. ${ }^{102}$

Bickel's argument as to the importance of the Court's leeway to "do neither" in any given case rests, therefore, on the insight developed at length by Professor Charles L. Black, Jr.: In any assessment of the work of the Court, the function performed by that body in legitimating the actions of other agencies of government has central importance. ${ }^{103}$ Bickel states: $(1962)$.

99. A. Bickel, The Least Dangerous Branch: The Supreme Court at the Bar of Politics

100. The same objection is cited in H. Wechsler, Princtples, Polmics, and Fundarantat. Law xiv (196I).

IOI. A. Bickex, supra note 99 , at 57-65.

102. Id. at $68-69$ (italics in original). $(1960)$.

103. See C. Black, The People and the Court-Judicial Review in a Denocracy 56-86 
[I]t is no small matter, in Professor Black's term, to "legitimate" a legislative measure. The Court's prestige, the spell it casts as a symbol, enable it to entrench and solidify measures that may have been tentative in the conception or that are on the verge of abandonment in the execution. Regardless of what it intends, and granted that it often intends no such thing, the Court can generate consent and may impart permanence. ${ }^{104}$

\section{Bickel's differences with Wechsler are thus defined:}

The rule that the Court must legitimate whatever it is not justified in striking down fails to attain its intended purpose of removing the Court from the political arena; rather, it works an uncertain and uncontrolled change in the degree of the Court's intervention, and it shifts the direction. In the course of achieving this result, it excises a great deal of what the institution is capable of doing without undue offense to democratic theory and practice. At the root is the question-in the large - of the role of principle in democratic government. No attempt to lift the Court out of the [tension between principle and expediency] can be successful. The rule of the neutral principles merely distorts the tension, by placing the weight of the Court most often on the side of expediency; for that weight is felt whenever the Court legitimates legislative choices on the constitutional merits. The Court is able to play its full role, as it did in [Brown], maintaining itself in the tension on which our society thrives, because it has available the many techniques and devices of the mediating way between the ultimates of legitimation and invalidation. ${ }^{105}$

Thus, Bickel's response to the concrete problem presented by benevolent quotas is to refer to Naim v. Naim ${ }^{106}$ in which "the Court found no insuperable difficulty in leaving open the question of the constitutionality of antimiscegenation statutes [by dismissing an appeal from a state-court decision upholding their constitutionality], though it would surely seem to be governed by the principle of [Brown]," and to suggest "that the Court should similarly leave open such an issue as is offered by benevolent housing quotas." 108

The variety of "mediating devices" that Bickel's theory makes available to the Court, however, includes more than dismissals of appeals and denials of certiorari. The bulk of The Least Dangerous Branch is devoted to a comprehensive survey of the work of the Court ranging from cases arising under the commerce clause ${ }^{108}$ to such decisions as Kent v. Dulles ${ }^{109}$ and Garner v. Louisiana, ${ }^{110}$ which, although they raised constitutional issues, were decided on nonconstitutional grounds. Bickel presents Kent v. Dulles as an instance of the Court's using the "delegation" doctrine to "remand" to Congress for a "second look" a statute raising serious constitutional

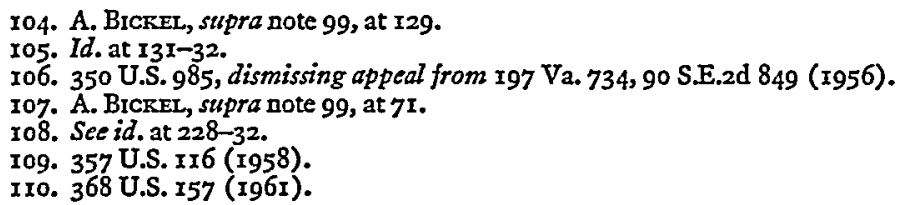


doubts ${ }^{111}$-a type of analysis that Bickel, together with Professor Harry Wellington, had earlier adumbrated in an article suggesting application of the "remand" technique to Section 301 of the Taft-Hartley Act. ${ }^{112}$

In Garner, the Court reversed the Louisiana convictions of a group of "sit-ins" who had been prosecuted under a statute that prohibited the commission of certain acts "in such a manner as would foreseeably disturb or alarm the public."113 The ultimate constitutional issue raised by the case was the validity, under the fourteenth amendment, of the use of state power to enforce the discriminatory policies of lunch-counter owners. The Court, however, did not reach the constitutional merits: The ground for reversal was that the state had introduced no evidence at trial to show that the public was being unreasonably disturbed or alarmed.

Analyzing the case, Bickel first notes that "[i]t is not credible that a conviction of disturbing the peace would be reversed for lack of evidence that the public might be alarmed"114 in analogous circumstances-a peaceful demonstration involving nudity, for example, or a peaceable refusal either to produce a ticket for, or to leave, a seat at a Carnegie Hall concert. But " $[t]$ he defendants were Negroes sitting at a white lunch counter; and as Justice Douglas, who differed from the majority and spoke to the merits, pointed out, this was Louisiana."'115

"[E]verything else being equal," Bickel argues,

the Court would normally have left to the local trier of facts the choice of which inference [as to whether or not the public was unreasonably disturbed or alarmed] to draw. Surely the decisive factor in Garner was that everything else was jarred into being unequal by the looming presence, in the background, of a momentous constitutional issue. All this is not to say that the holding in the Garner case is intellectually untenable. It is to say only that by its own intrinsic significance such a holding was not necessarily to be expected or even likely. It is explained and justified as probably the most suitable and certainly the narrowest method of avoidance consistent with the equities that favored the defendants, the method with the fewest surrounding implications. For the upshot is merely that this prosecution failed for reasons that are easily curable ....116

Whether the Court's disposition is phrased in terms of lack of ripeness, excessive delegation, or vagueness, whether what is involved is a denial of certiorari, dismissal of an appeal, or a decision so narrowly confined as to be applicable only to the facts then before the Court, whether the "remand" for a second look is to the legislature, as in Kent v. Dulles, or to the prose-

III. See A. Bickel, supra note 99, at 164-66.

II2. See Bickel \& Wellington, Legislative Purpose and the Judicial Process: The Lincoln Mills Case, 7 I Harv. L. Rev. I, 28-35 (1957).

II3. 368 U.S. at 165 .

II4. A. BICKEL, supra note 99, at 178.

II5. Id.

II6. Id. at I79. 
cutor, as in Garner, the distinguishing characteristic of the "mediating devices and techniques"-the Court's "passive virtues"-is the avoidance of a decision on the constitutional merits. What makes the passive virtues so important, in Bickel's view, is:

When the Court . . . stays its hand, and makes clear that it is staying its hand and not legitimating, then the political processes are given relatively free play. Such a decision needs relatively little justification in terms of consistency with democratic theory. . . . [I]n withholding constitutional judgment, the Court does not . . . abandon principle. It seeks merely to elicit the correct answers to certain prudential questions that . . . lie in the path of ultimate issues of principle. To this end, the Court has, over the years, developed an almost inexhaustible arsenal of techniques and devices. Most of them are quite properly called techniques for eliciting answers, since so often they engage the Court in a Socratic colloquy with the other institutions of government and with society as a whole concerning the necessity for this or that measure, for this or that compromise. All the while, the issue of principle remains in abeyance and ripens. "The most important thing we do," said Brandeis, "is not doing." He had in mind all the techniques, of which he was a past master, for staying the Court's hand. They are the most important thing, because they make possible performance of the Court's grand function as proclaimer and protector of the goals. These are the techniques that allow leeway to expediency without abandoning principle. Therefore they make possible a principled government. ${ }^{117}$

What needs to be noted, finally, is the intimate connection between Bickel's "mediating devices" and the techniques of adjudication long since embodied in the common-law tradition as canons of judicial craftsmanship. Law made by judges - common law-is not law until it is applied by a court, and it is crucial to Bickel's theory that constitutional law is judgemade law. ${ }^{118}$ At the level of craftsmanship, a common-law judge might well appraise the passive virtues as no more than applications of the venerable injunction that decisions be based on the narrowest possible ground, a connection Bickel himself draws at one point. ${ }^{118}$ Given Bickel's presuppositions, however, the techniques for applying constitutional law in con-

II7. Id. at 70-7I.

II8. See id. at 69-70: "When it strikes down legislative policy, the Court must act rigorously on principle, else it undermines the justification for its power. It must enunciate a goal, it must demonstrate that what the legislature did will not measure up, and it must proclaim its readiness to defend the goal-absolutely, if it is an absolute one. But it is not obligated to foresee all foreseeable relevant cases and to foreclose all compromise. Indeed, it cannot. It can only decide the case before it, giving reasons which rise to the dignity of principle and hence, of course, have a forward momentum and broad radiations. But the compelling force of the judgment goes only to the actual case before the Court. If it were otherwise, another part of the justification for the existence of the power [of judicial review] would be destroyed. For, as we have seen, the Court's peculiar capacity to enunciate basic principles inheres in large part in its opportunity to derive and test whatever generalization it proclaims in the concrete circumstances of a case. This is an opportunity that a legislature, constrained to generalize prospectively and hence in a sense abstractly, cannot have. I have remarked that the function of judicial review arises in the limiting context of cases, and yet, while the Court should not surmount the limitation, it must rise above the case. And while the Court should rise above the case, it must not surmount the limitation."

rig. See id. at Ir2. 
crete cases have implications far beyond those of judicial craftsmanship. At the center of Bickel's analysis of the work of the Court is the importance of "not doing"-the insight that the timing and vehicle of constitutional decisions are deserving of the same attention as their content. The resolution of questions of timing and circumstance, moreover, simultaneously defines the terms of the "colloquy" between the Court and other agencies of government. Thus, the passive virtues are far more than craft techniques governing the application of judge-made constitutional principles. They are also, in Shapiro's terms, maxims of political jurisprudence.

B.

Bickel's entry into the lists as a defender of the Court was met with cries of outrage from the "modest." ${ }^{120}$ The objections to Bickel's thesis were basically three: First, use of the mediating devices eventuated in unprincipled, albeit nonconstitutional, grounds of decision in cases raising constitutional issues; second, some of the mediating devices, notably dismissals of appeals based on considerations of ripeness, constituted an unprincipled flouting of jurisdictional directives imposed on the Court by Congress; and third, once the Court accepted Bickel's counsels of expedience as to nonconstitutional decisions, it would inevitably apply the techniques for accommodating political pressures to decisions on the constitutional merits, which would themselves thus become unprincipled. ${ }^{121}$

The content of the first two objections can be illustrated briefly in terms of cases that have already been discussed. The objection to Garner, for example, would be that the Court there avoided the constitutional merits only by deciding that southern prosecutors, in "disturbing the peace" cases, would have to proffer more evidence than their northern counterpartsin short, that in the service of avoiding the "momentous constitutional issue" looming in the background, the Garner convictions were ultimately voided on the wholly unprincipled ground that " $[t]$ he defendants were Negroes sitting at a white lunch counter; and ... this was Louisiana." Similarly, the Naim dismissal, which Bickel explains "in terms of the discretionary considerations that go to determine the lack of ripeness,"122 was branded by Wechsler as being "wholly without basis in the law."123

The basic "modest" objection to Bickel's view that dismissals of appeals rest largely in the discretion of the Court is that, in contrast to the discretion embodied in the certiorari jurisdiction, the relevant congressional

120. See, e.g., Gunther, The Stubtle Vices of the "Passive Virtues"-A Comment on Principle and Expediency in Judicial Review, 64 CoLUM. L. REV. I (Ig64).

I2I. See id.

I22. A. BICKEL, supra note 99 , at I26.

123. H. WeCHSLER, Toward Neutral Principles of Constitutional Law, in Princripres, PoLITICS, and Fundamental IAw 3, 46-47 (196I). See also Gunther, supra note 120, at 16-20; Wechsler, Book Review, 75 YALE L.J. 672, 675-76 (r966). 
statutes appear to make the appellate jurisdiction mandatory. It is preeminently these dispositions, therefore, that provide the basis for the charge that Bickel would transform a principled institution into a political one. Bickel himself admits:

It follows that the techniques and allied devices for staying the Court's hand, as is avowedly true at least of certiorari, cannot themselves be principled in the sense in which we have a right to expect adjudications on the merits to be principled. They mark the point at which the Court gives the electoral institutions their head and itself stays out of politics, and there is nothing paradoxical in finding that here is where the Court is most a political animal. ${ }^{124}$

But why do the "modest" refuse to accept the justifications offered by Bickel for the political accommodations that he prescribes? As we have seen, the "modest" insistence on adhering to the terms of the congressional mandate is derived from the premise that the Court, because it is an institution incapable of being held to account by the public, ought not, except in extraordinary circumstances, to impose its own views where those views contradict decisions reached by the electorally responsible agencies of government. As his many references to "democratic theory and practice" suggest, however, and as his discussion of "The Counter-Majoritorian Diffculty" makes explicit, ${ }^{125}$ the limitations on the Court's power derived by the "modest" from the fact of political irresponsibility are central to Bickel's approach. Indeed, the thrust of his effort is precisely to afford the Court the maximum possible opportunity to avoid taking stands on constitutional issues.

The differences between Bickel and, for example, Wechsler thus have nothing whatsoever to do with the opposition of those who counsel judicial activism to those who advocate judicial restraint. There is simply nothing in Bickel's system that would lead a Court following his prescriptions to be any more active than one embracing Wechslerian edicts. The source of their differences is, rather, that Bickel's view of the Court's "legitimation" function requires him to postulate that the Court acts politically even when it validates another agency's actions and that the consequences of such a decision must therefore be weighed as carefully as the consequences of an invalidation on constitutional grounds.

In Bickel's view, therefore, the Court's lack of electoral accountability requires not acts of legitimation that necessarily involve political consequences, but rather the "doing nothing" that "gives the electoral institutions their head." Consequently, what separates the two approaches to dismissals of appeals is that it is Bickel, not Wechsler, who is "modestly"

124. A. Bickel, supra note 99, at 132 .

125. See id. at $16-23$. 
willing to let the Court protect itself and the society from exercise of the power of decision that the statute governing appeals seeks to thrust upon it.

The structure of the judicial "politics" delineated by Bickel, moreover, is composed of elements developed in the schools of his most vociferous critics. Thus, the functional and institutional significance of concepts such as ripeness, standing, and case and controversy have been elucidated in a succession of both scholarly works and judicial opinions attributable to such men as Wechsler, Frankfurter, Louis Jaffe, Henry Hart, Albert Sachs, Philip Kurland, and Gerald Gunther. These are the men who so ably delineated for the profession the precise senses in which courts and legislatures interact to "make" law. It was, indeed, Hart and Wechsler's monumental The Federal Courts and the Federal System ${ }^{126}$ that expounded the myriad ways in which doctrines such as ripeness not only define jurisdiction but, by deciding jurisdiction, simultaneously determine the timing and impact of judicial decisions.

Bickel's analysis of the Court's "legitimation" function is thus thoroughly grounded in the approach to the work of the Court that informs The Federal Courts and the Federal System. Similarly, his focus, in analyzing Garner, on the actual impact of that decision in terms of the interplay among state and federal trial and appellate courts, prosecutors, state legislatures, and Congress is wholly consistent with the perspectives developed by Hart and Wechsler in that work. The fact is, moreover, that the system developed in The Federal Courts and the Federal System was proving itself too rigid to be capable of accounting satisfactorily for much of the recent work of the Court. Over time, the tone of commentators' analyses had gradually shifted from one that marks the explications of the critic to one more characteristic of the strictures of the opponent. ${ }^{127}$ Bickel's modification of that system, therefore, as contrasted, for example, to the approach of Wechsler's article on neutral principles, has at least the compelling virtue of providing a structure in terms of which much of that work can satisfactorily be explained.

Against this formidable array of merits, Bickel's critics bring to bear the insistence that dismissals of appeals on the grounds of ripeness are unjustified, not only because they involve the flouting of a congressional mandate, but also because they represent denials of a judicial obligation to decide properly tendered constitutional issues-abdications of that duty to

I26. H.M. Hart \& H. WechsLer, The Federal Courts aNd the Federal System (I953).

127. See, e.g., the following forewords to the Harvard Law Review annual survey of the work of the Supreme Court: Jaffe, Foreword, 65 Harv. L. REv. I07 (195I); Freund, Foreword: The Year of the Steel Case, 66 HARv. I. Rev. 89 (I952); Sacks, Foreword, 68 HARv. L. REv. 96 (I954); Brown, Foreword: Process of Law, 72 HARv. L. REv. 77 (1958); Hart, Foreword: The Time Chart of the Justices, 73 HARv. L. REv. 84 (1959); Griswold, Foreword: Of Time and Attitudes-Professor Hart and Judge Arnold, 74 HARv. L. REv. 8x (I960); Kurland, Foreword: "Equal in Origin and Equal in Title to the Legislative and Executive Branches of the Government," 78 HARv. I. REV. I43 (I964). 
decide from which Wechsler drew his justification for the institution of judicial review. ${ }^{128}$ As in the instances we have already examined, Bickel's response to this argument is wholly faithful to the tradition of The Federal Courts and the Federal System, focusing sensitively on the functional differences in the roles our system of government assigns to the lower state and federal courts and to the Supreme Court:

The pressure for individual justice is, of course, all the stronger when one may fairly surmise that the tendency of the Court, if pushed to the wall of principled judgment, would likely be to vindicate the moving party's constitutional claim. How should a man feel who has lost on what he must regard as a technicality, having asserted a principle that two years later, in a similar case, carries the field? ${ }^{129}$

In considering this problem, Bickel notes first that the fact that "the equities on the side of the moving party will vary in intensity . . . is not an argument relevant to the issue of principle itself. It can only make more palatable [if those equities are weak] the use of a device of avoidance that works against the moving party." ${ }^{\text {"130 }}$ His argument continues:

In any event, the policy of avoidance, if otherwise applicable, must prevail, despite hardship to the litigant and despite what is in other circumstances a strong policy in favor of authoritative and speedy pronouncement of governing rules. There are crucial differences-which, of course, the opinions in Marbury $v$. Madison and Cohens $v$. Virginia seek to obscure-between the role of the Supreme Court in constitutional cases and the function of courts of general jurisdiction. The latter sit as primary agencies for the peaceful settlement of disputes and, in a more restricted sphere, as primary agencies for the vindication and evolution of the legal order. They must, indeed, resolve all controversies within their jurisdiction, because the alternative is chaos. The Supreme Court in constitutional cases sits to render an additional, principled judgment on what has already been authoritatively ordered. Its interventions are by hypothesis exceptional and limited, and they occur, not to forestall chaos, but to revise a pre-existing order that is otherwise viable and was itself arrived at by more normal processes. Fixation on an individual right to judgment by the Supreme Court is, therefore, largely question-begging. ${ }^{131}$

The vociferousness of the opposition to Bickel's counseling dismissals of appeals cannot, therefore, be explained simply as an expected reaction to a radical departure, for it is clear that Bickel built entirely on the foundations previously laid out by his critics. The basis for that opposition can perhaps best be illuminated by reference to another tradition that, like the law, attempted the necessary but impossible feat of defining relevance and thus ordering existence-that of Gothic cathedrals.

Sainte Chapelle, the chapel of the French kings in Paris, consists of one tall room whose walls, with the exception of one area near the base, are

128. See H. WechsLer, Toward Neutral Principles of Constitutional Law, in Prunciples, PoLITICS, AND FUNDAMENTAL LAW 3, 4-I5 (196I).

129. A. Bicrel, supra note 99, at 172 .

130. Id. at 173 .

I3T. Id. 
composed entirely of glass. Clearly Sainte Chapelle is Gothic; the elements of design indicate immersion in that tradition, and the search for light, which marked the transition from Romanesque to Gothic, is consummated in the luminosity its construction made possible. Sainte Chapelle in this sense represents the culmination of the Gothic tradition.

Yet, in another way, the chapel must have been a thoroughly disturbing presence for those habituated to the Gothic pattern. For the illusion created by the building is that there is nothing but luminosity, that the structural members, the elements that the chapel was to order, have completely disappeared. The child, then, if child it was, was an offspring difficult to recognize, and therefore to legitimate-not because it was not within the tradition, but because, like The Least Dangerous Branch, it was more than the culmination of an old style. It was also the beginning of a new perspective.

\section{C.}

In one sense, therefore, the objections to The Least Dangerous Branch are understandable, for the new elements introduced by Bickel must eventually prove irresistible. The old tradition is exploded and the new begins.

The instability of the equilibrium between the traditional and the novel embodied in Bickel's approach is demonstrated by at least three factors that that approach fails to explain satisfactorily. First, there is the problem presented by the number and variety of the considerations that Bickel assumes the Court brings to bear upon its utilization of the mediating devices. Thus, if Bickel's Justices need be no more activist than those of Wechsler, it is nevertheless true that they have a great deal more discretionary power with which to be nonactivist. And for Bickel, who shares Hand's premises as to the limitations imposed upon the Court by the fact of its political irresponsibility, ${ }^{132}$ the existence of such discretion necessarily presents a dilemma.

Bickel's response to this dilemma, like that of his predecessors to the more limited discretion entailed by their more limited conception of the Court's permissible leeway, is to insist upon rationality, upon "intellectually tenable" dispositions, in those areas of accommodation where wholly principled decisions are untenable. Wechsler had tried to confine the Court's discretion within boundaries sufficiently narrow to obviate the possibility of the Justices becoming the Platonic Guardians feared by Hand; Bickel's modification of that theory postulates Guardians who are Platonic not only in their exercise of power, but also in their wisdom: possessed of a degree of rationality exceeding that vouchsafed to Wechsler's Justices by precisely the extent to which the discretion Bickel bestows on the Court exceeds that conceded by Wechsler. 
We need not be cynics to conclude from what we know of the Justices, and especially of the processes that lead to their appointment, ${ }^{133}$ that a Court meeting those specifications could be produced only by the sheerest accident. Yet, under Bickel's theory, only such Justices would be capable of legitimately exercising the discretion granted the Court. Bickel has not, then, in fact, satisfactorily accounted for the recent work of the Court we know. What he has done is to explain how a hypothetical Court might justifiably have arrived at many of those same decisions.

Secondly, Bickel's analysis of the Court's "legitimation" function-the fulcrum that enabled him to move the Wechslerian world-itself rests on the dubious assumption that the society will always perceive the difference between "doing nothing" and "legitimation." If, however, the Court "does nothing" long enough, if it leaves undisturbed-because the issue is unripe, because further experimentation is needed, or because it wants to "give the electoral institutions their head"-a sufficient number of lower-court dispositions at variance with those the Court would reach "if pushed to the wall of principled judgment," those decisions may well be perceived as legitimated. Indeed, given a sufficiently notorious case, even denial of certiorari might have such an impact. Conversely, a sufficiently prolonged series of invalidations on nonconstitutional grounds might well be perceived as an attempt to implement an unspoken constitutional judgment.

Bickel's counter to this objection is to stress the Court's "resources of rhetoric," its educational role, in Eugene Rostow's phrase, as "teacher in a vital national seminar." ${ }^{\text {134 }}$ But that rejoinder is convincing only if we assume that the public responds rather to what the Court says than to what it does, and that "legitimation" is effective only when the deed is accompanied by words of approval. The more likely hypothesis is that the public responds to the results the Court reaches as well as to the rhetoric it employs.

Given these limits on the usefulness of rhetoric, the objection that Bickel raises to Wechsler's "rule that the Court must legitimate whatever it is not justified in striking down" can be applied to his own counsel to "do nothing": It "fails to attain its intended purpose of removing the Court from the political arena." ${ }^{2135}$ What it does do is to change, and to some extent limit, the degree of the Court's intervention in that arena. But this consequence, which is also entailed by Wechsler's rule, must ultimately be as unsatisfactory for Bickel as Bickel assumed it would be for Wechsler. Both Bickel and Wechsler, for the same reason-the desire to render exercise of the Court's power compatible with the fact of its political irresponsibility

133. See, e.g., D. Danelski, A Supreme Court Justice Is Appointed (I964).

134. Rostow, The Democratic Character of Judicial Review, 66 HaRv. L. Rev. x93, 208 (I952); see A. Bickel, supra note 99 , at 26.

I35. See text accompanying note I05 supra. 
-attempt to formulate courses of action that will take the Court out of politics. Both, though for different reasons, fail.

There remains, finally, the problem raised by Bickel's barring of anything analogous to the mediating devices from the formulation of decisions on the merits of constitutionality-what Professor Gunther refers to as "the novelty and vulnerability of the Bickel thesis: the emphasis on principle as the highest Court duty, but only in a limited sphere of Court actions; the $100 \%$ insistence on principle, $20 \%$ of the time. ${ }^{.136}$ Gunther, of course, is concerned with the other 80 percent of the cases. What he regards as unjustifiable is, for example, the stress on prudential factors contained in the following explanation offered by Bickel for the dismissal of the appeal in Naim:

But would it have been wise, at a time when the Court had just pronounced its new integration principle, when it was subject to scurrilous attack by men who predicted that integration of the schools would lead directly to "mongrelization of the race" and that this was the result the Court had really willed, would it have been wise, just then, in the first case of its sort, on an issue that the Negro community as a whole can hardly be said to be pressing hard at the moment, to declare that the states may not prohibit racial intermarriage? ${ }^{13 t}$

But if, contrary to Gunther, we accept Bickel's view as to the propriety of the mediating devices, the query implicit in Gunther's characterization of that view nevertheless remains unanswered. If, that is, Bickel is correct in asserting that prudential factors properly influence dispositions based on the unprincipled mediating devices, on what basis does he deny that such factors ought properly to influence decisions on the constitutional merits: decisions that, because they attract greater public attention, are most likely to entail the type of consequences that, for Bickel, justified the dismissal of Naim?

Similarly, the structure of Bickel's analysis of Garner makes it likely that he would meet the objection that that analysis involves southern prosecutors having to produce more evidence than northern prosecutors in "disturbing the peace" cases by asserting that the relationship between the dangers involved in "legitimating" a given statute or conviction and the demand for "intellectual tenability" is an inverse one: that the greater the dangers involved in "legitimation," the more readily the Court may properly resort to a mediating device. ${ }^{138}$ Thus, Bickel would argue that in Garner the constitutional issue "looming in the background" was sufficiently momentous to justify resort to an extremely narrow ground of decision, one open to the objection canvassed above. Again, if, contrary to Gunther,

136. Gunther, supra note 120, at 3.

137. A. BiCkEL, supra note 99, at 174 .

I38. See text accompanying note 1 I 6 supra. 
we accept this analysis, the question implicitly posed by Gunther nevertheless remains: Why, in Bickel's view, is an analogous equation not applicable to constitutional decisions? If, in short, the sorts of factors that for Bickel justify the dismissal of Naim and the disposition in Garner properly enter into the Court's decision as to when to decide constitutional issues, why does Bickel deny the propriety of those factors playing any part in the Court's decision as to how to decide such issues-as to the terms of the constitutional decision itself?

The answer, in simplest terms, is that, as we have seen, Bickel is with Hand and Wechsler in drawing the need for principled constitutional decisions from the fact of the Court's political irresponsibility. Like Wechsler, moreover, Bickel defines principle in terms of generality; "By 'principle," according to Bickel, "is meant general propositions ... organizing ideas of universal validity in the given universe of a culture and a place . . . ."138 Given this agreement, it is perhaps to be expected that two of the three major constitutional decisions whose lack of neutrality Wechsler analyzed at length, ${ }^{140}$ Shelley v. Kraemer ${ }^{141}$ and Smith $v$. Allwright, ${ }^{142}$ are not discussed by Bickel at all. They are mentioned, indeed, only once each, and then in footnotes. ${ }^{143}$ As for Brown $v$. Board of Education, ${ }^{144}$ the third of Wechsler's examples, Bickel's proposed dismissal of cases raising the constitutionality of benign quotas obviously presupposes that the Court ought not strike down such quotas on the merits-that the principle underlying Brown, the impermissibility of racial classifications, does not, at least in this place and this culture, possess "universal validity."

Bickel accepts, then, Wechsler's proposition that constitutional decisions are justified only when they are based on neutral principles, and, on the level of concrete cases, he fails to traverse Wechsler's averment that certain of the Court's most important recent decisions are to be found lacking in neutrality. The Least Dangerous Branch can thus truly be characterized as an exercise in the usefulness of mediating devices, for Bickel's response to Wechsler, in terms of the cases on which the latter relies, is ultimately explicable only as an instance of confession and avoidance.

D.

That Bickel's analysis of the Court's work eventuates in assessments that are congruent with those of Wechsler is clearly apparent in his recent ap-

139. A. Bickes, stpra note 99, at x99; cf. id. at 69: "When it strikes down legislative policy, the Court must act rigorously on principle, else it undermines the justification for its power. It must cnunciate a goal, it must demonstrate that what the legislature did will not measure up, and it must proclaim its readiness to defend the goal-absolutely, if it is an absolute one."

140. See H. WeCHSLER, supra note $\mathrm{I28}$, at 36-42.

14I. 334 U.S. I (1948).

142. 321 U.S. 649 (1944).

143. See A. BICKEI, supra note 99, at I9I n. 24,24 I n.55.

I44. 347 U.S. 483 (1954). 
praisal of the obscenity decisions. ${ }^{145}$ Bickel there condemns the per curiam decision in the three cases jointly decided in Redrup $v$. New York ${ }^{148}$ as having "made an utter shambles of the law of obscenity." His objection is that the publications held in Redrup not to be obscene cannot meaningfully be distinguished from the material on the basis of which the conviction of Ralph Ginzburg had been upheld one year earlier: ${ }^{148}$

All there is of an effort to differentiate Mr. Ginzburg's case in the short orderit is hardly an opinion-that the Court wrote in the three cases . . . is the remark that in these cases there was no "evidence of the sort of 'pandering' which the Court found significant in Ginzburg v. United States." The pandering notion was based on Ginzburg's advertising, and embodies the bizarre proposition that Ginzburg's publications, even if not otherwise obscene, were made so by his sales pitch, which emphasized that they were sexually interesting. That, as Mr. Justice Douglas very sensibly said in dissent in the Ginzburg case, would make the constitutional protection of the Song of Solomon depend on the way it was sold, and might turn into unlawful obscenity a lot of "lotions, tires, food, liquor, clothing, autos, and even insurance policies," sold with the aid of displays "of thighs, calves, bosoms" etc. But be that as it may, and assuming that the pandering test does have some validity, it is impossible to see how publications . . . held not obscene [in Redrup] pander any less than Ginzburg's product. ${ }^{149}$

The deficiencies Bickel finds in the Redrup opinion are aggravated, moreover, by the fact that "there was hardly any explanation this time. Most of that, such as it was, came [in Ginzburg and its accompanying cases]. Now the Court said virtually nothing; it simply acted." ${ }^{.150}$ In deciding Redrup in a per curiam order that briefly adumbrated the bases on which various Justices, by differing routes, reached the conclusion that the material at issue was not obscene, the Court was seemingly returning to a "practice that it had previously followed for nine years, from I957 to rg66."151

I957 was the year of Roth $v$. United States, ${ }^{152}$ in which the Court first attempted to develop guidelines for the obscenity area. ${ }^{153}$ What followed, as a recent commentary has put it, is that

[f]or nearly a decade afterwards, the Court could muster a majority only for cryptic per curiams; in the two cases where the Justices wrote full-dress opinions ... no more than three of them could agree on a common rationalization. Initial efforts to clarify Roth broke down in a dispute whether the "community" re-

r45. See Bickel, Obscenity Cases, New Republic, May 27, I967, at 15.

I46. 386 U.S. 767 (I967).

I47. Bickel, supra note $\mathrm{x} 45$, at 17 .

I48. Ginzburg v. United States, 383 U.S. 463 , rehearing denied, 384 U.S. 934 (I966).

I49. Bickel, supra note 45 , at $\mathrm{x} 6$.

I50. Id. at I5.

I5I. $I d$.

I52. 354 U.S. 476 (1957).

153. For a concise and perceptive analysis of the difficulties inherent in those guidelines see Comment, More Ado About Dirty Books, 75 YALE L.J. I364, I365-77 (1966). 
ferred to in the Roth definition was a national or local one; attempts to establish the relevance of "social importance" were similarly unsuccessful. One Justice suggested that the prurient interest rule be supplemented by elements such as "patent offensiveness"; another, that Roth be applied in conjunction with a "sufficient evidence" rule in reviewing lower-court decisions; still another, that Roth be limited to federal cases. Mr. Justice Stewart urged the Court to replace Roth entirely with a "hard core pornography" rule, promising that although he was unable to define the hard core, he would know it when he saw it. From the start Mr. Chief Justice Warren offered a "purveying" test as an alternative, claiming that the conduct of the distributor rather than the content of his wares should be the central issue. Few of the proposals won the support of anybody but their authors. ${ }^{154}$

That Bickel finds these dispositions objectionable is clear, since it was this course of decision that he believes led lower courts, and Mr. Ginzburg, to the conclusion that "just about anything is printable in the US today"155 -a conclusion emphatically, and, according to Bickel, unjustifiably, rejected in Ginzburg $v$. United States.

"The problem [of obscenity]," Bickel concludes,

is exceedingly difficult-quite likely insoluble at the hands of the Supreme Court. On principle it would seem clear that, while government may take a hand in helping parents and schools to control what juveniles read and see, and while government should also have the power to control displays that thrust themselves unavailingly at people who may feel offended by them-with these two exceptions, anyone should have the right to print and publish and show anything that anyone else may wish to read and see. But . . . it seems equally clear that a majority of our people are not prepared to accept such a broadly permissive rule, and that their unwillingness to accept it is based in some part on surmises about the possible connection between pornography and crime. That there is no such connection may be likely. But no one is able to prove it.

In such circumstances, it is neither wise nor is it possible, as a practical matter, for the Court to impose and enforce a broadly permissive constitutional rule. And short of a broadly permissive rule, as the Justices have amply demonstrated, there is no coherent and consistent constitutional principle on which to rest judicial judgment. There is merely-but that is a great deal-an opportunity, through procedural, interpretive and other decisions falling short of the attempt to impose ultimate constitutional prohibitions, to discourage, circumscribe, reduce and contain the application of obscenity statutes. This is the business the Supreme Court ought to get on with. ${ }^{156}$

The principled disposition of the obscenity problem being ruled out, for prudential reasons analogous to those that for Bickel governed the disposition in Naim, we are thus left with the counsel of the passive virtues. Unlike the areas with which Bickel dealt in The Least Dangerous Branch, however, his analysis of the obscenity issue in fact involves a wholesale

I54. Id. at I373-77 (footnotes omitted).

155. Bickel, supra note 145 , at 15 .

I56. Id. at 17. 
condemnation of the Court's recent work in the area. The per curiam dispositions in Redrup and the post-Roth cases are only explicable as holdings on the merits of the constitutional issue of obscenity, and such holdings, on Bickel's analysis, are unjustifiable. In other words, Bickel can avoid Wechsler's characterization of Naim as "wholly without basis in the law" by arguing, as he does, that dismissals of appeals, even dismissals "for the want of a substantial federal question," need not be principled because they do not in fact represent dispositions on the merits. ${ }^{157}$ But this avenue is closed to Bickel in the obscenity area since, whatever else may be said of the per curiam dispositions we have been canvassing, it is apparent that they disposed of the issue presented on its constitutional merits.

Shapiro's fears for the Court's loss of a "reputation for candor," it will be recalled, are in part based on the per curiam dispositions in the segregation cases. ${ }^{158}$ And Wechsler, while agreeing that those dispositions are rightly to be condemned, begins his survey of illegitimate recent decisions with a number of pre-Roth per curiam dispositions in the area of film censorship. ${ }^{159}$ On the basis of Bickel's analysis of the obscenity issue, therefore, we may conclude that he is with Shapiro and Wechsler in being unable to offer a satisfactory account of the Court's recent per curiam practice. Bickel's strictures may be couched in more sophisticated language, but that fact in no way mitigates the severity of the indictment of the Court's recent work that his analysis of the obscenity cases entails. ${ }^{160}$

I57. "It can be said, and indeed it is commonly assumed, that dismissals "for the want of a substantial federal question' are decisions on the merits, though without opinion. But when the Court decides the merits without opinion, it is in the habit of telling us so by issuing a summary order that reverses or affirms the judgment below. There is and has been for many years a great deal that is pure fiction in this explanation. Many are the dismissals for the want of a convenient, or timely, or suitably presented question." A. Brckel, supra note 99, at 126 (footnote omitted).

A striking confirmation of Bickel's view is to be found in Mr. Justice Harlan's dissenting opinion, which Mr. Justice Clark joined, in Redrup: "The three cases were argued together at the beginning of this Term. Today, the Court rules that the materials could not constitutionally be adjudged obscene by the States, thus rendering adjudication of the other issues unnecessary. In short, the Court disposes of the cases on the issue that was deliberately excluded from review, and refuses to pass on the questions that brought the cases here [the issues of scienter, "vagueness," and "prior restraint"].

"In my opinion these dispositions do not reflect well on the processes of the Court, and I think the issues for which the cases were taken should be decided. Failing that, I prefer to cast my vote to dismiss the writs in Redrup and Austin as improvidently granted and, in the circumstances, to dismiss the appeal in Gent for lack of a substantial federal question. I deem it more appropriate to defer an expression of my own views on the questions brought here until an occasion when the Court is prepared to come to grips with such issues." 386 U.S. at 772 (emphasis added).

The description given by Mr. Justice Harlan of the Court's handling of certain summary dismissals in early reapportionment cases is also instructive: "Each of these recent cases is distinguished on some ground or other in Baker $v$. Carr. . . Their summary dispositions prevent consideration whether these after-the-fact distinctions are real or imaginary. The fact remains, however, that between 1947 and 1957 , four cases raising issues precisely the same as those decided today were presented to the Court. Three were dismissed because the issues presented were thought insubstantial and in the fourth the lower court's dismissal was affirmed." Reynolds v. Sims, 377 U.S. 533, 6r4 (1964) (dissenting opinion) (footnote omitted).

158. See text accompanying note 97 supra.

I59. See text accompanying note 96 supra.

I60. Cf. Bickel \& Wellington, supra note II2, at 3: "The Court's product has shown an increasing incidence of the sweeping dogmatic statement, of the formulation of results accompanied by little or no effort to support them in reason, in sum, of opinions that do not opine and of per curiam orders that quite frankly fail to build the bridge between the authorities they cite and the results they decree." 
$\mathrm{V}$.

The ultimate source of the difficulties in Bickel's analysis is, as we have seen, the postulate that he shares with Hand and Wechsler: that the Court's political irresponsibility requires-though, for Bickel, only in a delimited category of cases - an absolute adherence to principle. That what we know of the legislative and executive branches renders meaningless a comparative characterization of the Court as politically irresponsible has already been indicated. ${ }^{101}$ Nor can it realistically be asserted that the absolute form of limitation that Bickel and Wechsler would impose is required to prevent the Court from becoming excessively powerful. Unlike Congress or the President, the Court has access to neither sword nor purse, and in many areas, including such crucial contemporary concerns as foreign affairs, its recognition of its own limitations has amounted to almost total abdication. ${ }^{102}$

The issue central to both Bickel's and Wechsler's analyses is, therefore, not power but propriety. The charge is not that the Court is in some abstract sense exercising more power than our system of government allocates to it. What Bickel and Wechsler conclude, rather, is that recent dispositions, because they are not based on neutral principles, betray an abuse of the Court's admitted power to render constitutional decisions. The issue, then, is one of defining criteria for justifiable decisions.

A.

The starting point for any such formulation must be the insight that underlies Bickel's development of the passive virtues: that the Court, as an institution, has certain institutional needs-for example, the needs to ensure survival and to operate efficiently - and that those needs are necessarily reflected in the form and content of its work. The active role played by the Court in securing passage of the Judiciary Act of $x 925,{ }^{163}$ the "Judges" Bill" whose introduction of certiorari made possible control of the docket at a time when the number of cases awaiting decision threatened to cripple the Court as an effective institution, constitutes a response to the need for efficient operation. And Bickel's rationale for dispositions such as Naimthe necessity for maintaining the "tension between principle and expediency"-ultimately rests on the Court's need to ensure its own survival as a viable institution.

"The Court's authority to employ [mediating devices]," notes Bickel, "derives from its ultimate function of rendering principled adjudications;

I6r. See part III-C supra.

I62. See, e.g., Banco Nacional de Cuba v. Sabbatino, 376 U.S. 398 (I964); text accompanying note 56 supra. 48 U.S.C.).

163. Act of Feb. 13, r925, ch. 229, 43 Stat. 936 (codified in scattered sections of Io, II, 15, 28, 
for this is a function that can be wisely and fruitfully exercised only if the Court is empowered also to decide whether and when to exercise it."104 The Court's duty to render constitutional decisions thus entails, for Bickel, the power to determine the timing and scope of such decisions-entails, in other words, the Court's power to determine its own institutional capacity. It is precisely this reasoning that forms the basis for Bickel's approval of dismissals of appeals on grounds of ripeness.

In an earlier article, Bickel and Wellington, quoting Mr. Justice Frankfurter, advanced the view that the Court's power to determine its own institutional capacity derives directly from the principles of article III of the Constitution:

The earliest declaration of unconstitutionality of an act of Congress-by the Justices on circuit-involved a refusal by the Justices to perform a function imposed upon them by Congress because of the non-judicial nature of that function. . . . Since then, the Court has many times declared legislation unconstitutional because it imposed on the Court powers or functions that were regarded as outside the scope of the "judicial power" lodged in the Court by the Constitution. . . .

One may fairly generalize from these instances that the Court has deemed itself peculiarly qualified, with due regard to the contrary judgment of Congress, to determine what is meet and fit for the exercise of "judicial power" as authorized by the Constitution. ${ }^{185}$

Whatever the merits of this attempted derivation from the constitutional text, however, there exist a variety of devices for avoiding "controversy" and thereby ensuring survival, many of which have become so integral a part of adjudicatory techniques that the Court is often criticized for failure to observe them. One instance is provided by the maxim that a decision ought always to be based on the narrowest possible ground, as a means both of preserving flexibility for the future and of avoiding the conflict of judicial and public opinion that would likely result from more sweeping dispositions. Bickel commends this course to the Court, ${ }^{166}$ and Gunther takes pains to argue that nothing Wechsler proposes is inconsistent with that maxim. ${ }^{187}$ Cognate propositions, such as the importance of submerging individual doctrinal differences in compromise opinions that can speak for a majority of the Court and the importance of refraining from dissent in order to make unanimous decisions possible, ${ }^{168}$ rest, like that mandating the choice of the narrow ground, both on the desirability

I64. A. BickeL, supra note 99, at 205.

r65. Textile Workers Union v. Lincoln Mills, 353 U.S. 448, 464-65 (r957) (dissenting opinion), quoted in Bickel \& Wellington, supra note II2, at 28 .

I66. See A. Bicker, supra note 99 , at II2.

167. See Gunther, supra note I20, at 20 (discussing Cohens v. Virginia, I9 U.S. (6 Wheat.) 264 (I 82 I), on which Wechsler heavily relies).

I68. See A. Bickel, The Unpublished Opinions of Mr. Justice Brandeis: The Supreme CouRT AT WORK I 8-19, 28-32, 58, 65, 99, 161-62, 199-200, 203, 209-io (I957); Murphy, Marshaling the Court: Leadership, Bargaining, and the Judicial Process, 29 U. Cin. L. REv. 640, 656-72 (x962). 
of the Court's maintaining a united front and on the importance of obviating the possibility of conflicting decisions.

It was these considerations that underlay the assertion by Justices Frankfurter, Clark, Harlan, and Whittaker that the noting of probable jurisdiction in Ohio ex rel. Eaton v. Price ${ }^{169}$ "manifest [ed] disrespect by the Court for its own process."170 Regarding Eaton as "completely controll[ed]" by a case decided within two weeks of the time the Eaton papers came before the Court, ${ }^{171}$ the four Justices objected to the Court's "willingness to create an opportunity to overrule a case decided only a fortnight ago after thorough discussion at the bar and in the briefs and after the weightiest deliberation within the Court."'172

The issue involved in Eaton, however, was admittedly a weighty onethe propriety of warrantless searches in a noncriminal setting. Might it not be argued, therefore, that the four Justices who voted to note probable jurisdiction, far from manifesting disrespect for the Court's processes, were actually following Wechsler's injunction that they act on principle? Since they regarded the earlier decision as a serious infringement of constitutional rights, might not their insistence that the Court give plenary consideration to every extension of that case, no matter how small the variation in the facts presented, be characterized, again borrowing Wechsler's terms, as a praiseworthy refusal to bow to "controlling sentiment" and "to trim and shape their speech and votes accordingly" ?173 A year later, when Eaton was affirmed by an equally divided Court, the four Justices who had voted to note probable jurisdiction took care to point out, referring to the earlier, controlling decision: "We would not be candid to say that on its own facts we have become reconciled to that judgment." of refusal to be bound by decided cases help to provide a basis for that "reputation for candor" whose loss Shapiro fears?

The proper answer to these questions, a negative one, entails the assertion that a Court that often indulged in controversies like Eaton would suffer greatly-not only from the inability to utilize its time and resources efficiently that must result from the insistence that certain issues never be regarded as even temporarily settled, but also from the loss of public esteem that must eventually be caused by spectacles as unseemly as that provided by Eaton. Such an answer indicates much about the extent to which the institutional values of efficient operation and survival form the necessary

x69. 360 U.S. 246 (1959).

I70. Id. at 248-49.

I7I. Frank v. Maryland, 359 U.S. 360 (x959).

I72. 360 U.S. at 249.

173. H. WECHSLER, supra note $\mathrm{I} 28$, at $2 \mathrm{I}$.

174. Ohio ex rel. Eaton v. Price, 364 U.S. 263,269 (I960). The four Justices who voted to note probable jurisdiction joined in an opinion urging that Frank be either reversed or distinguished. The Frank case has since been overruled in Camara v. Municipal Court, 387 U.S. 523 (I967). 
underpinning for any analysis of the work of the Court. But it indicates more than that as well, for the emphasis on loss of public esteem as providing a justifiable basis for criticism of Eaton recalls the earlier analysis of the degree of generality - of neutrality, in Wechsler's terms-that suffices to render a decision justifiable. A decision is to be regarded as justifiable, it was there concluded, when its generality is perceived as adequate by the public. ${ }^{175}$

B.

As the Eaton analysis makes clear, the necessary limitation on judicial "candor," like the Wechslerian insistence on neutrality as necessary to the enforceability of the Court's decisions, ultimately represents a requirement of public acceptance. Nor is this a limitation peculiar to the judicial branch, for in the last analysis, obedience over the long term even to congressional statutes can be enforced neither by the sword nor by the purse. The continued existence of all branches of our government, not just the judiciary, is at bottom dependent upon public acceptance. That acceptance is not at issue, however, in the normal course of events. Inertia is a guiding principle in politics as well as physics, and the very existence of our institutions -the persuasive testimony of history-itself serves to produce a significant degree of acceptance.

It is the reservoir of acceptance produced by this inertia that is drawn upon by the Court whenever it renders a decision less than adequately general, and the reservoir is far from inexhaustible. Why, then, render such decisions at all? Why not follow Wechsler's advice and validate acts of other governmental agencies or, following Bickel, resort to the "passive virtues"? The answer is that public acceptance of the Court does not rest solely on perceptions of adequately general decisions. That acceptance rests also, to a very considerable degree, on a view of the Court as the guardian of our constitutional rights. Given this view, each approval of a statute perceived as involving an infringement of constitutional rights-even, in some instances, refusals to rule on the merits of such a statute-results in a loss of credibility, and therefore public acceptance, of the Court. ${ }^{176}$

The loss of acceptance resulting from a loss of credibility, like that produced by a decision perceived as inadequately general, depends, of course, on the seriousness with which the public views a given constitutional infringement or a given instance of inadequate generality. The requirements of credibility and generality will, moreover, be inconsistent wherever a statute perceived as constituting an infringement of constitutional rights

I75. See part III-F supra.

176. See Scharpf, Judicial Review and the Political Question: A Functional Analysis, 75 YALE L.J. $517,562-66$ (1966). 
can be struck down only on a basis perceived as inadequately general. The crucial point, however-the point that Bickel refuses to accept-is that resort to the "passive virtues" does not resolve this dilemma. It simply ignores one factor in the equation, for the fact is that every decision not to decide, just like decisions on the constitutional merits, may result either in adding to the reservoir of public acceptance (if only by remaining unnoticed, and thus adding to the inertial acceptability produced by the Court's continued functioning) or in depleting that accumulation. And depletion may as easily be the consequence of a lack of credibility as a lack of generality.

Bickel's significant contribution to analysis of the Court's work is the description of the multitude of factors that may necessitate a compromise with doctrinal purity-with the adequate generality on which Wechsler insists. There is the Court's need to ensure itself the flexibility that will be required in future cases, where the issue presented is manifested in such a diverse variety of circumstances that no principle is yet at hand, or where available principles are seen to entail ramifications in other areas that have not yet fully been explored. There is the Court's need, wherever possible, to maintain a united front, both to retain public acceptance and to preserve uniformity and therefore stability within the law. There is the need to accommodate the pressures and needs of other governmental institutions, including lower federal and state courts and federal and state administrative agencies, whose attitudes towards a given decision may have a significant impact on the way in which it is enforced, as well as federal and state executive and legislative institutions, which may be considering taking action in a field with which the Court is presently concerned, or whose later actions may have drastic implications for any decision reached by the Court. There is, finally, as in Bickel's analysis of Naim, the limitation imposed by the public acceptability of the result reached in the given case.

What Bickel failed to see, the flaw upon which Gunther correctly insists, is that this analysis is workable only if it is applied to decisions on the constitutional merits as well as to the mediating devices. Thus, that same public whose refusal to accept the $N$ aim result justified the disposition of that case may, in another case, regard a given result as so urgently required that refusal to reach it would entail a loss of credibility far outweighing the consequences of inadequate generality. The point is that the weighing of the factors delineated by Bickel is a task that the Court must undertake in each and every case, whether what is involved is a mediating device or a decision on the constitutional merits. If these factors represent "political" considerations, in other words, then the Court is in politics, and the counsel of passive virtues ultimately avails as little as the injunction of neutral principles to extricate the Court from that status. 
It is precisely this failure that makes it impossible for Bickel convincingly to distinguish dismissals for want of a substantial federal question from per curiam dispositions without opinion. Thus, as his analysis of the obscenity issue indicates, Bickel subjects per curiam dispositions involving constitutional questions to the same rigorous requirements of principle applicable to cases decided with full opinion. Appeals dismissed for want of a substantial federal question, however, often involve, as Naim did, a constitutional question, and the existence of a congressional statute making the hearing of appeals mandatory seems to entail the proposition that such a dismissal involves a decision on the merits about the substantiality of the constitutional question presented. Denial of this proposition, which Bickel characterizes as "pure fiction," is mandated, as we have seen, by the necessity for the Court to be able to determine its own institutional capacity. ${ }^{178}$ Yet the only distinction Bickel offers between such dismissals and decisions on the merits without opinion is the fact that the latter "habitually" involve "issuing a summary order that reverses or affirms the judgment below."179 The point seems somehow too formal, too concerned with the mechanics of the Clerk's office, to account satisfactorily for the distinction between dispositions subject to a requirement of rigorous adherence to principle and dismissals for which that requirement may justifiably be treated as a "fiction."

The question Bickel never satisfactorily answers, the query insistently put by Gunther, may thus be reformulated in more precise terms: If the Court's need to preserve its institutional capacity by avoiding needless public controversy justified the dismissal of $\mathrm{Naim}$, notwithstanding the existence of a mandatory appeals jurisdiction, why would not a similar need to avoid loss of the Court's credibility in a situation where enunciation of the principle involved would cause needless public controversy justify a per curiam disposition, reaching the required result without opinion? One response given in connection with criticisms of the Court's per curiam practice $^{180}$ is that reasoned opinions constitute the source of the Court's power, and that a refusal to make clear the grounds of decision in each case must ultimately result in the Court's decrees becoming unenforceable. Such a response ignores the reservoir of public acceptability provided for the Court by the inertial effects we have already analyzed. But the more serious difficulty in terms of Bickel's theory is that acceptance of this argument would go far towards rendering unjustifiable many of the mediating devices, including, of course, dismissals for want of a substantial federal question.

I77. See A. Bicked, stupra note 99, at 126 .

178. See text accompanying note 164 stupra.

I79. A. BiCKEL, supra note 99, at I26.

180. Cf. Brown, supra note I27; Sacks, supra note I27. 
Thus, Bickel agrees that reasoned, principled opinions constitute the source of the Court's power, but his description of the importance of the mediating devices rests on the insight that not every case provides the proper occasion for such an opinion-that often, as in Naim, what is called for is not the reasoned opinion, but rather the passive virtue. Bickel's more likely response, therefore, is that a disposition without opinion in the per curiam situation is unjustifiable because such a disposition represents a decision on the merits that must be principled; because it, unlike the dismissal of an appeal, is not truly a mediating device. Such an argument, however, serves only to restate the question why dismissals of appeals do not represent decisions on the merits. Bickel cannot, after all, simply wish out of existence the congressional statute making appeals mandatory; and the argument that dismissals can be differentiated from per curiams because the Court does not in fact treat the former as binding precedents ${ }^{181}$ can be met by reference to Bickel's own analysis of Ginzburg, which convincingly demonstrates that the Court there did not regard earlier per curiams as entitled to precedential weight. ${ }^{182}$

The search, therefore, must be for the factor that makes dismissal of an appeal a justifiable mediating device - the significance, in Bickel's terms, of the absence of an order affirming or reversing the judgment below. Viewed in terms of a focus upon public acceptability, the significance of that absence seems clear, for it results in a decision that in form, in appearance, represents not a decision on the merits, but simply a refusal to decide. The justifiability of treating dismissals as a mediating device thus lies precisely in the disparity between the public and the lawyer's view of the significance of such a decision. We can therefore say, with Bickel, that it is a fiction that dismissals of appeals involve decisions on the merits, not because that proposition is a fiction in the universe of the legal scholar, but because the scholar's world does not in itself contain all the relevant materials from which a satisfactory account of the work of the Court can be drawn.

If, however, we focus with Bickel on the impact of a given decision on the public that is ultimately the source of the Court's power, it is clear that decisions without opinion do often serve as mediating devices. The limitations on the use of this device are, of course, considerably more severe than in the case of dismissals; but what is involved are differences, not antitheses. Thus, there is a significant probability that certain cases will be sufficiently notorious that a decision without opinion would be perceived as enunciating an inadequately general principle, just as there is a lesser probability that certain dismissals would be perceived as refusals to enforce constitu-

I8r. See note 157 supra.

I82. See text accompanying notes $154-56$ supra. 
tional rights sufficiently significant to lead to a loss of credibility. Similarly, it is probable that a whole series of dispositions without opinion in a given area would lead to a significant loss of public acceptance resulting from a perception of inadequate generality, and this eventuality is more likely than a series of dismissals resulting in a loss of credibility. But the question ultimately is one of a difference in probabilities, not of antitheses. To further complicate matters, moreover, any complete description would require modification of Bickel's unlikely assumption that legal scholarship is so completely isolated from the world on which Court decisions impinge that scholarly criticism of an opinion's refusal to give precedential weight to a series of "fictional" dismissals cannot become sufficiently vociferous and well known as to result in a loss of public acceptance.

The crucial point, once again, is that the same factors that provide justification for the passive virtues come into play in connection with decisions avowedly on the constitutional merits. If it is the form of dismissals of appeals-the appearance of not deciding-that accounts for their designation as mediating devices, then the stringently limited form of dispositions without opinion-the appearance of deciding without any radiating effects-must also suffice to qualify the per curiam practice as a passive virtue. The relevant characteristic of the per curiam is thus precisely the absence of any full-dress opinion, ensuring, in the absence of other circumstances leading to public notoriety, that the public impact of the Court's action, as in the case of dismissals, is held to a minimum.

Such an analysis does not, of course, purport to demonstrate that dispositions without opinions invariably represent a mediating device as desirable as dismissals. As indicated above, the limitations on the use of this device are more severe than is true of dismissals, and the likelihood that factors outside the Court's control, such as the actions of the press or the scholarly community, will result in the public's perceiving the disposition as inadequately general is greater than in the case of dismissals. With those qualifications, however, the same reasoning that leads to the designation of dismissals as legitimate passive virtues must also be applicable to the per curiam practice. We may, therefore, criticize the Court's per curiam practice, as we might criticize its dismissal actions, for discounting too drastically the likely reactions of the press and the scholarly community, for example, or for resorting to dispositions without opinion for too extended a period in any given area, since any long series of such decisions tends to increase the likelihood of a public perception of inadequate generality. What we cannot do, and this is precisely what Bickel attempts, is simultaneously accept dismissals as legitimate mediating devices and yet criticize the per curiam practice on the basis that dispositions without opinion are not entitled to the same status. 
Assimilation of per curiams to the status of passive virtues, moreover, involves a good deal more than simply expanding the scope of application of the latter. For, as we have seen, Bickel's justification for drawing the line between per curiams and dismissals of appeals is that the former truly embody what the latter only "fictionally" represent-decisions on the constitutional merits. And decisions on the constitutional merits, unlike the mediating devices, are subject to the rigorous requirements of principle. Recognition of per curiams as one of the passive virtues entails, therefore, the proposition that the pressures that compel resort to the mediating devices, which for Bickel justify the decision in Naim, also have their part to play in the disposition of cases on the constitutional merits. To some, extent, of course, this view is implicit in Bickel's treatment of Garner, which, as we have seen, ultimately rests on the proposition that justifiable demands for "intellectual tenability" are inversely related to the dangers involved in legitimating the situation before the Court. ${ }^{183}$ Garner, however, although a decision on the merits, was not a decision on the constitutional merits; and the crucial point about many of the per curiams, once again, is precisely that they are decisions on the constitutional merits. In this sense, therefore, classification of per curiams as a mediating device ultimately does far more than simply shift the line that Bickel draws between dismissals of appeals and the per curiam practice. What it entails, rather, is destruction of the barrier Bickel seeks to erect between principled decisions and the mediating devices.

C.

A satisfactory theory of the work of the Court cannot stop, however, with the assimilation of the per curiam practice into the world of passive virtues. It must also account for the phenomenon against which much of the recent criticism has been directed, for what Bickel and Wellington referred to as the

increasing incidence of the sweeping dogmatic statement, of the formulation of results accompanied by little or no effort to support them in reason, in sum, of opinions that do not opine and of per curiam orders that quite frankly fail to build the bridge between the authorities they cite and the results they decree..$^{184}$

That description has since been echoed in numerous critical appraisals, ${ }^{185}$ and the phenomenon it reports is presumably also what Shapiro depicts as the Court's lack of "candor" and Wechsler as a lack of "principle."

Criticism has, of course, always accompanied the work of the Court, and the accusation of a lack of "candor" or "principle" may to some extent

I83. See text accompanying note $\mathrm{I}_{3} 8$ supra.

I 8 . Bickel \& Wellington, supra note II2, at 3 .

185. See, e.g., L. HAND, THE BiL, of Rights (1958); Brown, supra note 127; Griswold, supra note I27; Hart, stipra note I27; Kurland, supra note 127. 
rest simply on a refusal to accept the legitimacy of the mediating devices. As Bickel demonstrates, however, the Court has resorted to such devices throughout its history. Even if one views them as unprincipled, or as lacking in candor, their use means only that the Court's product has continued to be as deficient as it always has been. What Bickel reports, however, and what the recent critics object to, is something more-not the same old level of imperfection, but an "increasing incidence" of failure.

One could, of course, simply brand these failures as illegitimate decisions and leave it at that. Imprecation, however, is a poor substitute for understanding. And even a work that purports not to describe the ongoing work of the Court, but only to delineate the role that such an institution may legitimately fulfill, is more likely to persuade if it is based on an accurate diagnosis of the institution's ills. Any satisfactory theory, therefore, must account not only for the necessary level of lack of principle that has always characterized the work of the Court, a requirement Bickel ably satisfies, but also for the fact of an "increasing incidence" of failure, a task Bickel wholly ignores.

Assuming that the quality of personnel staffing an institution remains reasonably stable and that no significant changes occur in the internal institutional processes (and there is nothing in the recent history of the Supreme Court to vitiate either of these assumptions), striking variations in work product are likely to represent responses to change in the environment in which the institution operates. The environment in which the Supreme Court operates has recently been subject to two significant changes-neither of them unknown in prior eras, neither of them without considerable roots in history, but both having assumed significant proportions only in the years following I945.

The first of these changes has to do with increased public awareness of the possibilities for social change inherent in constitutional litigation. In part this is a diffuse, general consciousness resulting simply from more widespread education and from developments in communications that ensure that an increasing proportion of the public learns of Court decisions, and has access to speculation concerning the consequences of those decisions, almost as soon as they are handed down. More significantly, it is this awareness that has increasingly guided the behavior of organized groups, a phenomenon symbolized by the carefully conceived campaign of litigation that eventuated in the Brown decision. ${ }^{288}$ A decisive effect of such group activity is the extent to which it predetermines the sequence of issues brought before the Court in any given area. One of the most important of the passive virtues has historically been the property of randomness in the

I86. See generally Vose, Litigation as a Form of Pressure Group Activity, 319 ANNaLs 20 (1958). 
flow of litigation, which made it unlikely that the Court, after deciding any given case, would immediately be faced with the situation that most stringently tested the principle enunciated. It is precisely this saving element of accident, this opportunity to avoid the testing of the outermost limits of a principle, that has been eliminated by the activity of groups whose aim it is to utilize litigation as a means of pursuing social goals.

One response by the Court to this activity has been to utilize an organization possessing considerable legal resources that, in addition to furthering its own interests through litigation, has also demonstrated a regard for the institutional needs of the Court. The Office of the Solicitor General has increasingly been cast in this role, as is demonstrated by its recent participation in cases in which the interests of the United States were not directly involved-the Reapportionment Cases and the Brown decision provide two striking examples. In instances such as the second Brown decision, ${ }^{187}$ the Court's request for participation by the Solicitor General has eventuated in arguments displaying a sensitive regard for the importance of mediating devices and the Court's institutional capacity. ${ }^{188}$

A second response, rooted in the considerations so thoroughly canvassed in The Least Dangerous Branch, has been an increasing incidence of resort to the passive virtues, including the mediating device represented by the per curiam practice. The series of cases denying retroactive effect to various decisions in the field of criminal procedure ${ }^{189}$ represents one such instance, analogous to the second Brown decision. To understand a second instance, the handling of the obscenity issue, requires consideration of the second significant change in the Court's environment-the breakdown of accepted limitations on the meaning of constitutional concepts.

Dean Bayless Manning, in an incisive analysis demonstrating the inapplicability of constitutional limitations to the exercise of power by private business corporations, stresses the narrowly delimited nature of the freedoms embodied in our constitutional guarantees. His conclusion that those guarantees cannot meaningfully be applied to the corporate area is based on the fact that the freedoms they ensure are freedoms from arbitrary interference only by governmental agencies and only in a restricted number of areas, largely political rather than economic. The economic freedoms, including freedom from hunger and deprivation; the cultural and intellectual freedoms, including freedom to develop talents to the utmost limits of capacity and to express those talents; "positive" rather than "negative" freedoms; and freedoms whose attainment would implicate the actions of non-

I87. Brown v. Board of Educ., 349 U.S. 294 (I955) (implementation decision).

I88. See A. BickeL, supra note 99, at 252-53.

I89. See, e.g., Johnson v. New Jersey, 384 U.S. 719 (1966); Tehan v. United States ex rel. Shott, 382 U.S. 406 (1966); Linkletter v. Walker, 381 U.S. 618 (1965). 
governmental agencies, all were largely ignored when our Constitution was written. ${ }^{190}$

Strict observation of such limitations vastly simplified the task of the Court in defining the applicability of constitutional guarantees. Thus, the Court has not historically been in danger of losing its "reputation for candor" when it failed to consider the applicability of a given constitutional principle to deprivations of economic or cultural freedoms. And a constitutional principle was perceived as adequately general even when it was applied only to attempts by governmental agencies to interfere with political freedoms. As the scope of the freedoms regarded as relevant expands, however, both candor and adequate generality must become increasingly difficult to achieve.

The limitations that have thus helped to make the Court's work manageable are not to be found explicitly set out in the constitutional texts. They exist, rather, as cultural understandings, as implicit assumptions, and it is precisely these agreements that have increasingly been breaking down. A primary example is the traditional understanding of the scope of the equal protection guarantee. The Court's recent expansion of the applicability of this guarantee has been designated "the egalitarian revolution" by Professor Kurland, one of the Court's most vociferous scholarly critics, who considers this expansion the most "novel" of the themes that have characterized the work of the Court over the past decade. ${ }^{201}$

When he wrote those words, Kurland had in mind the reapportionment and segregation decisions; ${ }^{192}$ but he might with equal justification have included the recent decisions in the area of criminal law, which he considers primarily as examples of "the effective subordination, if not destruction, of the federal system." ${ }^{\text {"193 }}$ True, decisions such as Gideon $v$. Wainwright ${ }^{104}$ and Escobedo v. Illinois ${ }^{195}$ are phrased in terms of sixth amendment guarantees, and Miranda v. Arizon ${ }^{196}$ is couched in fifth amendment language. But Gideon emphasizes the fact that "there are few defendants charged with crime, few indeed, who fail to hire the best lawyers they can get to prepare and present their defenses," ${ }^{2107}$ and Escobedo relies on the "lesson of history that no system of criminal justice can, or should, survive if it comes to depend for its continued effectiveness on the citizens' abdication through unawareness of their constitutional rights."188 Clearly, then,

19o. See Manning, Corporate Power and Individual Freedom: Some General Analysis and Particular Reservations, 55 Nw. U.L. REv. 38, 46-53 (1960).

191. See Kurland, supra note 127 , at 144.

192. See id. at $145-62$.

193. Id. at I 44 ; see id. at I $63-65$.

194. 372 U.S. 335 (1963).

I95. 378 U.S. 478 (1964).

196. 384 U.S. 436 (I966).

197. 372 U.S. at 344 .

I98. 378 U.S. at 490. 
the theme that underlies these cases is one of equality: in Gideon, the imposition of a duty on the State to provide the same access to counsel for those who cannot afford to hire an attorney as for those who can; in Escobedo and Miranda, the duty to equalize, between those who are aware of their constitutional rights and those who are not, the opportunity for access to counsel prior to interrogation that may result in invocation of fifth amendment rights.

The equal protection basis for decision is most nearly explicit in cases such as Douglas v. California, ${ }^{109}$ which invalidated the practice of denying appointment of counsel for an indigent upon the independent determination of an appellate court that no purpose would be served by the appointment. The opinion in Douglas relied on Griffin v. Illinois, ${ }^{200}$ which had held that indigents must be given equal access to the procedures established by the States for reviewing criminal convictions. But as Mr. Justice Harlan pointed out in dissent, Douglas, unlike Griffin, did not deal with a problem of access to appellate review, for the procedures struck down in Douglas required the appellate court to make a complete review of the trial proceedings in determining that no purpose would be served by the appointment of counsel. ${ }^{201}$ What Douglas involved, rather, was the imposition of a duty on the State to equalize the quality of the indigent's participation in appellate procedures.

Mr. Justice Harlan clearly saw the implications of such a decision for the other criminal-procedure cases canvassed above:

[I] $f$ the present problem may be viewed as one of equal protection, so may the question of the right to appointed counsel at trial, and the Court's analysis of that right in Gideon v. Wainwright . . . is wholly unnecessary. The short way to dispose of [that case] . . . would be simply to say that the State deprives the indigent of equal protection whenever it fails to furnish him with legal services, and perhaps with other services as well, equivalent to those that the affuent defendant can obtain. ${ }^{202}$

Justice Harlan's basic objection to the decision was precisely the "novelty" of its interpretation of the constitutional guarantee of equal protection:

[T] he Equal Protection Clause does not impose on the States "an affirmative duty to lift the handicaps flowing from differences in economic circumstances." To so construe it would be to read into the Constitution a philosophy of leveling that would be foreign to many of our basic concepts of the proper relations between government and society. The State may have a moral obligation to eliminate the evils of poverty, but it is not required by the Equal Protection Clause to give to some whatever others can afford. ${ }^{203}$

199. 372 U.S. 353 (1963).

200. 35 I U.S. I2 (1956).

20I. See 372 U.S. at 363-64.

202. Id. at 363 .

203. Id. at 362 (footnote omitted). 
The extent to which the accepted limitations on the concept of equal protection have been eroded-whether the Court's "novel" interpretation will eventually be extended to such areas as payment for expert witnesses, and beyond-is not yet clear. As Douglas demonstrates, however, the process is under way. Ultimately, therefore, Kurland's failure to point to the criminal cases as exemplifications of "the egalitarian revolution" seems to stem from a failure to appreciate the real source of the "novel" constitutional doctrine he finds in the segregation decisions: the Court's partial recognition, reflecting a new awareness on the part of the public, that the freedom embodied in constitutional guarantees as they have historically been limited is, for the economically and socially disadvantaged, no freedom at all. Once that fact had been recognized in Brown, in connection with the impact on Negroes of segregated educational facilities, the drawing of its obvious implications for criminal law required only a further recognition of the empirical connection between poverty and crime.

The "novel" element in recent segregation and criminal decisions can thus largely be accounted for in terms of the relatively recent public (and judicial) awareness of the extent to which the world of the poor and of the Negro differs from that in which the bulk of the public lives, and of the consequences entailed by that disparity for the content of a meaningful constitutional guarantee of "equal protection." Moreover, the discovery of previously unknown universes existing within our boundaries is not the only example of an area of increased public and judicial consciousness in the United States in the post-World War II period. Due in part to the enforced world tours required of so many citizens by that conflict, and perhaps more to ongoing developments in communication and transportation, there developed a growing awareness of the divergent sexual standards characteristic of even closely related Western cultures.

The predictable result was confusion. Both a public that continued to hold to the accepted truth that society ought not to permit the dissemination of obscenity, and a Court that had translated that premise into the Roth formula that obscenity was not speech and was therefore not protected by first amendment guarantees, ${ }^{204}$ found themselves increasingly unable to agree on just what it was that had-of course-to be banned. Reflecting the public confusion, the absence of even a potential consensus on the nature and content of permissible areas of candor in sexual matters, a badly fragmented Court increasingly resorted to the passive virtues. Wherever possible, for nearly a decade after the Roth decision, "cryptic per curiams" were the order of the day.

204. See Roth v. United States, 354 U.S. $476,482-84$ (1957). 
D.

Bickel, of course, is fully aware of this lack of consensus, and it forms the basis for his counsel that the Court restrict the scope of obscenity statutes without ever ruling on the constitutional merits. ${ }^{205}$ But the circumstances in which several of the cases arose foreclosed, in the Court's view, avenues other than that of constitutional adjudication; ${ }^{206}$ and decisions on the merits, given the relatively acceptable content of the material that was usually at issue and the need of the Court to preserve credibility, had, in the main, to uphold the freedom to print and to read. Bickel correctly suggests that a "principled" exception to this pattern should be made for cases involving "displays that thrust themselves unavailingly at people who may feel offended by them."

Would application of this "principled" exception, however, entail the inconsistency noted by Mr. Justice Douglas, dissenting in Ginzburg, of making the obscene content of material depend on the advertising that preceded or accompanied it? That inconsistency could be avoided only if what the Court in fact condemned was the method and content of the advertising rather than the material being advertised. But that, of course, is precisely the purport of the "pandering" test advanced in Ginzburg. The content of the material involved in Redrup, as Bickel notes, ${ }^{208}$ cannot meaningfully be distinguished from that condemned in Ginzburg. But the Court in Ginzburg did not focus on the content of the material being disseminated; the pivotal inquiry was, rather, into the nature and content of the advertising campaign that accompanied it. ${ }^{209}$

The Ginzburg test is, admittedly, not stated in these terms, just as the per curiams that both preceded and followed that decision are impenetrably "cryptic" concerning the bases of decision. But that, as Bickel himself acknowledges in terms reminiscent of his justification for Naim, is surely attributable to the fact that "a majority of our people are not prepared to accept such a broadly permissive rule, and ... their unwillingness to accept it is based in some part on surmises about the possible connection between pornography and crime. That there is no such connection may be likely. But no one is able to prove it."210 The obscenity cases, therefore, no

205. See text accompanying note $\times 56$ supra.

206. See, e.g., A. Bickel, The Least Dangerous Branch: The Supreme Court at the Bar or PoLrrics $133-43$ (1962), outlining an alternative to the Court's having reached the merits in Times Film Corp. v. City of Chicago, 365 U.S. 43 (1961), a film-censorship case.

207. See text accompanying note 156 supra.

208. "[The materials involved in Redrup] . . . are no more distinguishable from Mr. Ginzburg's publications than were all those items that went before, from 1957 to I966." Bickel, Obscenity Cases, NEw Republic, May 27, 1967, at 15, I6. See also text accompanying note 149 szupra. 209. See Comment, More Ado About Dirty Books, 75 YALE L.J. 1364, 1386-88 (1966). 210. Bickel, supra note 208, at I7. 
less than the other examples surveyed by Bickel of the use of mediating devices, represent dispositions "seek [ing] merely to elicit the correct answers to certain prudential questions that ... lie in the path of ultimate issues of principle."211 They are attempts by the Court "to maintain itself in the tension between principle and expediency"121 - the tension "on which our society thrives."213

Bickel's objection to the obscenity decisions is not, however, an objection in the large. It focuses, rather, on "the rank injustice of punishing [Ginzburg] under a rule applicable to no one else, past or future."214 Because the per curiams preceding Ginzburg had seemed to indicate that "just about anything is printable in the US today," and because Ginzburg itself refused to make explicit the "principled" exception on which it was based, Bickel can only conclude:

The Court, we now know, made of Mr. Ginzburg an example which exemplifies nothing. Had any other institution been responsible for this performance-say some hapless administrative agency - the Court would have been well-justified in holding that it violated the Due Process and Equal Protection Clauses. ${ }^{215}$

In another context, as we have seen, Bickel himself exposed the flaw in this contention. In response to the argument that devices of avoidance could not legitimately be employed where they resulted in refusals to uphold individual claims that "the Court, if pushed to the wall of principled judgment, would likely . . . vindicate,"216 Bickel countered:

The Supreme Court in constitutional casess sits to render an additional, principled judgment on what has already been authoritatively ordered. Its interventions are by hypothesis exceptional and limited, and they occur, not to forestall chaos, but to revise a pre-existing order that is otherwise viable and was itself arrived at by more normal processes. Fixation on an individual right to judgment by the Supreme Court is, therefore, largely question-begging. ${ }^{217}$

We are all creatures of the injustices to which we have become accustomed. Ginzburg's conviction had already been upheld by one appellate court when the Supreme Court granted certiorari in his case. Had the Court simply denied certiorari at that point, would there then have been a rank injustice? The conclusion to be drawn from a negative answer, one that Bickel's prescription of mediating devices strongly suggests, must be that the Ginzburg decision and the obscenity per curiams, no less than the other passive virtues described by Bickel, represent the price society must

2rI. A. Bickex, supra note 206, at 70 .

212. Id. at 69 .

213. Id. at I32.

214. Bickel, stipra note 208 , at I6.

215. Id.

216. A. BickeI, supra note 206, at I72.

2I7. Id. at 173 . 
pay for maintaining the Court as a viable institution capable of fulfilling its assigned constitutional task. ${ }^{218}$

That price may be expected to increase as the factors of change sketched above continue to accelerate. It is not only the growth of self-conscious group litigation-although that is important and likely to become vastly more so as the legal agencies associated with the War on Poverty come into full operation-and the gradual breakdown of accepted limitations on constitutional concepts that dictate an increasing resort to the full panoply of mediating devices. In the last analysis, this trend toward "expediency" can be accounted for as a reaction to the continuing increase in both the tempo and content of constitutional litigation-an intensification and expansion that at bottom are produced not by a Court imperiously attempting to impose its will upon the nation, but rather by a nation with a population growing both in numbers and in education, a population ever more aware both of decisions of the Court and of the potentiality for social change inherent in those decisions.

In terms of any given decision, therefore, the Court may be open to criticism for espousing a wrong, or an inadequate, principle; for failing to resort to a passive virtue where such resort is both possible and proper; ${ }^{219}$ or for resorting to per curiam dispositions where a more limited and less controversial mediating device is available. ${ }^{220}$ In general, however, it is clear that the direction of change is such that the Court's task of constitutional adjudication must necessarily become an increasingly difficult one. The prognosis, then, is precisely one of an "increasing incidence" of failure.

\section{VI.}

Professor Bickel, moreover, is not alone in disapproving of the Court's handling of cases in the areas of obscenity and film censorship. Almost a decade ago, Mr. Justice Black made clear his objection to the Court's procedure of dealing with such cases at retail:

218. A similar price involving subordination of individual goals is exacted by the process of group litigation delineated in the text accompanying notes I86-88 supra. In the NAACP campaign that led to the Brown decision, for example, may there not have been individual plaintiffs who were condemned to an experience of exclusively segregated schooling, to a practical denial of the right being contended for, by the grade-a-year desegregation programs on which agreement was often reached?

Acceptance of the fact that in every viable society individual desires must at some point be sacrificed to institutional needs presumably also represents the solution to the equal protection problems raised by the practice, described in the text at notes $187-88$ stupra, of having the Office of the Solicitor General intervene in cases in which the United States has no direct pecuniary or governmental interest. Assuming that this practice has become an established one, suppose that after a Supreme Court decision has established a certain constitutional right, the Solicitor General receives a letter from someone being denied that right, reporting that no lawyer whom the writer can afford to hire is willing to take the case, and requesting assistance. Must the Solicitor General-an agency of government-respond affirmatively if the facts contained in the letter are true, or can he-and the Supreme Courtrestrict at will the occasions when, and the parties on whose behalf, intervention will take place?

219. See note 206 supra and accompanying text.

220. Cf. text accompanying note 156 supra. 
We are told that the only way we can decide whether a State or municipality can constitutionally bar movies is for this Court to view and appraise each movie on a case-by-case basis. Under these circumstances, every member of the Court must exercise his own judgment as to how bad a picture is . . . The end result of such decisions seems to me to be a purely personal determination by individual Justices as to whether a particular picture viewed is too bad to allow it to be seen by the public. Such an individualized determination cannot be guided by reasonably fixed and certain standards. . . . [The resulting] uncertainty cannot easily be reconciled with the rule of law which our Constitution envisages. ${ }^{221}$

Black's emphasis on "fixed and certain standards," like his objection to a case-by-case process of adjudication, recalls the differentiation between constitutional and common-law adjudication that he expressed in his Linkletter dissent ${ }^{222}$ in terms of the logic-experience dichotomy. ${ }^{223}$ But what is the danger posed for the development of constitutional law by resort to common-law methods of adjudication? A persuasive argument can be made that, far from eschewing such methods, a Court desiring to achieve that precision of analysis essential to the formulation of enduring constitutional principles could do no better than to adhere to the process of case-by-case adjudication:

[T] he framing of concepts and the integration of a conceptual system for the purpose of finding out where we are at, as a preliminary to seeing where we are to go next-that will remain eternally necessary to scientific advance. And at this point, the process of argument in court, or the judicial process, affords in the rival claims of the opposing lawyers a clarity of appreciation, forced upon few other men, as to the weasel ways of verbal symbols, as to the need for rigorous definition, the need for hunting postulates to their foul holes and yanking them out into brutal, healthy sun, the need for step-by-step reasoning which stays at every step within the premises as defined, whenever one sets about any such integration. ${ }^{24}$

What Black fears sufficiently to justify his sacrifice of the intellectual precision made possible by common-law processes is the exercise by the Court of that measure of discretion that a system of case-by-case adjudi-

221. Kingsley Int'l Pictures Corp. v. Regents, 360 U.S. 684, 690-91 (1959) (concurring opinion). 222. See note 46 supra and accompanying text.

223. Mr. Justice Black has recently reiterated this distinction in support of his dissenting position in Griswold v. Connecticut, $38 \mathrm{r}$ U.S. $479,507(1965)$ : "Observing that the right to privacy ... presses for recognition here,' today this Court, which I did not understand to have power to sit as a court of common law, now appears to be exalting a phrase which Warren and Brandeis used in discussing grounds for tort relief, to the level of a constitutional rule which prevents state legislatures from passing any law deemed by this Court to interfere with "privacy." "Id. at 5 I0 n.I (emphasis added).

224. Llewellyn, Legal Tradition and Social Science Method-A Realist's Critique, in Brooknngs Institution, Essays on Research in the Social Sciences 89, III (I93I); cf. Corbin, Hard Cases Make Good Law, 33 YALE L.J. 78 ( $x 923$ ).

Bickel shares this appreciation of the virtues of common-law methods of adjudication: "Another advantage that courts have is that questions of principle never carry the same aspect for them as they did for the legislature or the executive. Statutes, after all, deal typically with abstract or dimly foreseen problems. The courts are concerned with the flesh and blood of an actual case. This tends to modify, perhaps to lengthen, everyone's view. It also provides an extremely salutary proving ground for all abstractions; it is conducive, in a phrase of Holmes, to thinking things, not words, and thus to the 
cation inevitably entails. The connection between discretion and commonlaw adjudication is explicitly drawn by the prevailing opinion in Linkletter, which begins by establishing the Court's agreement with Austin, who "maintained that judges do in fact do something more than discover law; they make it interstitially by filling in with judicial interpretation the vague, indefinite, or generic statutory or common-law terms that alone are but the empty crevices of the law."225

Black's Linkletter opinion also makes explicit the basis for his opposition to the exercise of such discretion by the Court. The sentence immediately following the passage that objects to the reading of Holmes as identifying constitutional law with "experience" is as follows: "It should be remembered in this connection that no member of this Court has ever more seriously criticized it than did Justice Holmes for reading its own predilections into the 'vague contours' of the Due Process Clause."228 In other words, the Court may not in constitutional cases rely on "experience," may not exercise the discretion that case-by-case adjudication would entrust to it, because to do so would run the risk of repeating the occurrences of the I930's. That period, as the then Senator Black was well aware, was one in which the Court's attempts to block economic measures deemed necessary by the legislature and executive came near to destroying it as a viable institution.

It might be argued that, if the function of the Court is truly to afford our society an opportunity for "sober second thought" concerning measures that challenge, in some significant way, either cherished ideals or deep-rooted social beliefs, then the actions of the thirties were thoroughly in accord with that function. The fact is that the impropriety of government intervention in the economy did represent such a belief; and the effect of the Court's decisions was precisely to impress upon the society the magnitude of the departure from received tradition entailed by acceptance of the view that there exist no principled checks on governmental economic actions. The full implications of that acceptance are only now becoming apparent, as property rights once again begin to be perceived as necessary bulwarks of individual freedom. ${ }^{227}$ Even on a less long-range view, it is apparent that the Court's I930's decisions performed the task of legitimation that the cumbersomeness of the machinery for amending the Constitution has historically imposed upon the Court. Thus, the public

evolution of principle by a process that tests as it creates." A. Bickel, stipra note 206 , at 26 . Indeed, as we have previously seen, it is essential to Bickel's theory that constitutional cases are decided by means of common-law processes. See note I 8 supra and accompanying text.

225. 38I U.S. at 623-24. See also K. ILEWELLYN, The CoMMMON LAw Tradition 62-120 (1960). 226. 381 U.S. at 642 .

227. See, e.g., McCloskey, Economic Duse Process and the Supreme Court: An Exhumation and Rebutrial, I962 S. Cr. Rev. 34 ; Reich, The New Property, 73 YaLE L.J. 733 (I964); of. Struve, The Less-Restrictive-Alternative Principle and Economic Due Process, 8o HARv. L. Rev. I463 (I967). 
consensus on the propriety of the economic legislation of the I930's was ultimately strengthened, not weakened, as a result of the Court's intervention.

Whether or not that intervention was proper, the Linkletter dissent makes clear that Black's objection to case-by-case adjudication is rooted in his fear that the Court will abuse the discretion such a process necessarily involves. That fear is confirmed by what Black sees as the record of the Court's use of common-law "experience" as a guide to constitutional decisions. In Black's view, reliance on "experience" led, in the I950's, to a supplanting of the excesses of the r930's by the constitutional "balances" he so bitterly opposed. Black's solution to this dilemma is an insistence on "logic" - the logic of textual "absolutes" and of historical meanings.

The efficacy of relying on these two sources of logic for satisfactory guidelines in constitutional adjudication has been searchingly questioned by Bickel. ${ }^{28}$ What is crucial for present purposes, however, is that Black's system of constitutional "logic" can successfully eliminate the element of discretion in constitutional adjudication only if it provides a totally coherent and comprehensive system, whose principles never conflict with each other in any conceivable set of circumstances. Such a system, of course, satisfies Wechsler's criterion of neutrality interpreted as total generality. Under such a system, moreover, there would be no need for mediating devices and the avoidance of constitutional issues. Consequently, the Court, in each and every case, would be able to fulfill completely the requirement of "candor" with regard to the basis for decision that Shapiro seeks to impose upon it.

But to return momentarily to the Gothic mode, the fact is that the structure of the law embodies the diversity and incongruity of Chartres, not the rational order of Amiens or even of Notre Dame. It is no less true for constitutional law than for tort law that precedents serve, not as logical axioms from which conclusions can mechanically be derived, but as an accumulated store of wisdom against which the validity of new conclusions can be assessed. Nor are constitutional cases exempt from the transformations of meaning produced by history. Is the proposition for which Marbury $v$. Madison ${ }^{229}$ stands today the holding of that case? Is not Pierce v. Society of Sisters ${ }^{230}$ cited as establishing a first amendment right of which no trace can be found in the opinion? Is not Buchanan $v$. Warley ${ }^{231}$ cited as establishing an equal protection rather than a due process right?

As then Dean Rostow put it :

228. See A. Bickel, sispra note 206, at 84-T ro.

229. 5 U.S. (I Cranch) 137 ( 1803 ).

230. 268 U.S. 5 ro (1925).

23I. 245 U.S. 60 (1917). 
Any lawyer who has worked through a line of cases about easements or trusts or bills and notes or any other legal subject, knows that no court has ever achieved perfection in its reasoning in its first, or indeed in its twentieth opinion on the same subject. . . . [Even our greatest and most insightful judges] grapple with a new problem, deal with it over and over again, as its dimensions change. They settle one case, and find themselves tormented by its unanticipated progeny. They back and fill, zig and zag, groping through the mist for a line of thought which will in the end satisfy their standards of craft and their vision of the policy of the community they must try to interpret. The opinions written at the end of such a cycle rarely resemble those composed at the beginning. Exceptions emerge, and new formulations of what once looked like clear principle. If we take advantage of hindsight, we can see in any line of cases and statutes a pattern of growth, and of response to changing conditions and changing ideas. There are cases that lead nowhere, stunted branches and healthy ones. Often the judges who participated in the process could not have described the tree that was growing. Yet the felt necessities of society have their impact, and the law emerges, gnarled, asymmetrical, but very much alive-the product of a forest, not of a nursery garden, nor of the gardener's art. ${ }^{232}$

To substitute "logic" for "experience" in constitutional adjudication, therefore, would be to dispense altogether with the judicial process, at least the judicial process as known in the United States and in England.

The connection between the judicial process and the discretion that Black fears is perhaps best illustrated by the following example: Assume a logical chain of propositions (a) through (e), with the Court already having decided (a) and (b) in such a way as to indicate a particular result in (c), which result has not, however, yet been promulgated. Assume further, that case (e) then arises and that some combination of factors-with the Supreme Court, perhaps a need to maintain credibility that outweighs any loss of public acceptance foreseeable from a perception of inadequate generality-presses strongly for a resolution that conflicts with the indicated outcome, the "logical" decision, in (c). It is precisely here that the process of case-by-case adjudication maximizes the attention given to the "Alesh and blood" of the case before the court, "to things," in the phrase of Holmes quoted by Bickel, "not words." Outweighing the need to maintain doctrinal consistency, in short, is the fearsome pressure of decision, the knowledge that even a refusal to decide involves not only a continuation, but also in part a legitimation, of the (by hypothesis) undesirable status quo contained in the case presently at issue. In such a situation the measure of discretion inevitably entailed by common-law methods of adjudication is embodied in the pressure toward simply deciding the single case, toward reaching a decision in (e) that conflicts with the result indicated in (c),

232. Rostow, American Legal Realism and the Sense of the Profession, 34 Rocky Mr. L. REv. I23, $141-42$ (1962). 
and leaving to a later case, or to a later bench, the possibility of formulating an acceptable distinction in (d).

The description given above is not, of course, intended to suggest either that sloppiness in opinion writing ought to be condoned in common-law adjudication or that the dilemma being delineated will often be encountered. Nor can decisions such as that suggested in (e) long survive in the law if the issue on which they bear continues to be actively litigated. Unless within a reasonable period of time they become incorporated into an articulated, rationalizable exception to the general rule, they must inevitably become, in Rostow's phrase, "stunted branches," "cases that lead nowhere."

There is, however, another possibility, one canvassed by Bickel in connection with his justification for the Court's avoidance of the "momentous constitutional issue" lurking in the background of the Garner case: ${ }^{233}$ "But then, nothing may have to be faced, or what must be faced may arise in a different social and political context. As many a southern and border city has demonstrated, the sit-in problem is soluble-and beyond a doubt best solved-by processes other than judicial." ${ }^{234}$ Case (d), in other words, may never arise or, if it does, the factors that represented the potentiality for conflict with (c) and (e) may have been transformed beyond recognition by the passage of time. Is it too early to suggest that the Communist cases of the I950's are rapidly being assimilated to that status, that the recent transformations in the monolithic quality of the world Communist movement are rapidly rendering irrelevant the justification offered in those cases for the inapplicability of first amendment guarantees?

Whatever the applicability of this analysis to those particular decisions, it is clear that the alternative suggested by Bickel, the possibility that any particular formulation of a social or political problem may be only transitory, is what ultimately makes possible the art of government. That today's problems, even if not completely or rationally or logically soluble, will eventually be replaced by tomorrow's, is an insight that lies at the core of all political wisdom. It is also, of course, what Brandeis had in mind when he said of the Court: "The most important thing we do is not doing." And it is, finally, the ultimate justification for the common law's reliance on "experience," for the case-by-case methods of adjudication in terms of which common-law judges make the law.

In the last analysis, the wisdom of "experience" is a humbling one. "Often," Rostow tells us, "the judges who participated in the process could not have described the tree that was growing." Thus when a judge decides simply the case before him, when he focuses on things rather than words, 
the ultimate justification for his actions is not the certainty that he will reach the correct result in the particular instance. The certainty, rather, is that the words are inadequate, that even if a totally coherent and comprehensive system of law is theoretically possible, there is no warrant for believing that our judges are capable of finding and administering it.

Reliance upon common-law methods of adjudication, however, has consequences for society as well as for the judge. Thus, as we have seen, the rising incidence both of awareness concerning the Court and of group litigation tends to create a situation in which case (d) will rapidly be brought before the courts. Similarly, the breakdown of accepted limitations on the meaning of legal concepts, most evident in constitutional law but by no means confined to that area, makes it increasingly difficult to formulate even partially complete and coherent systems. This problem, the reverse side of the coin of "candor," arises because a widening of the meaning of fundamental legal concepts increases the number of situations to which a given principle is arguably applicable, and in which it may arguably conflict with some other principle. ${ }^{230}$

The heart of the difficulty is that stability represents one of the paramount demands that we make on the law. And stability is the child of "logic," of "clear and definite standards," and of the absence of conflict. The common law can meet this demand, it can achieve the status of "logic," but it can do so only over time, as the slow accretion of individual decisions works itself into a recognizable pattern. The key to the stability of the common law is, therefore, time: time in which to develop a pattern of decision whose meaning will be accessible to hindsight, and time in which to accommodate, in terms of shifting doctrine, the changes required of the law by changing social conditions. As the pace of social change accelerates, however, it is precisely the element of time that is increasingly denied to the common law. As a result, the prognosis for the continuing acceptability of case-by-case adjudication as the method by which constitutional litigation is conducted must eventually be the same as that for the Court's efforts to maintain satisfactory levels of principle and candor in the resolution of constitutional issues-one of an increasing incidence of failure.

\section{VII.}

Even apart from the effects of accelerating social change, it has always been true that the common law has existed in an uneasy tension between the "logic" of doctrine and the "experience," the "Alesh and blood," of the individual case. As is true of all common-law courts, much of the Supreme Court's prestige stems from the public's identification of the law with 
"logic," with the pattern of decision rather than with the individual case. And, as is again true of all common-law courts, it is this identification that ultimately accounts for the reservoir of public acceptance upon which courts draw, not only when adherence to doctrine results in an unpopular decision, but also when the need to preserve institutional capacity leads to a decision inexplicable in terms of received doctrine or when an error is committed in the exercise of discretion.

It is thus only partially correct to assert, as Bickel does in demonstrating the "question-begging" nature of a demand for "an individual right to judgment by the Supreme Court," that "[t]here are crucial differenceswhich, of course, the opinions in Marbury v. Madison and Cohens v. Virginia seek to obscure-between the role of the Supreme Court in constitutional cases and the function of courts of general jurisdiction." ${ }^{237}$ It would be more accurate to say that what the opinions in Marbury and Cohens are seeking to obscure is the fact that "logic" is not the whole of the law. The pressures requiring resort to "experience" are, of course, greater for the Supreme Court than for lower federal courts and the state judiciary. But the fact is that the Supreme Court is not alone, that it shares with all common-law courts the status of existing in the tension between the principled universe of "logic" and the expedient requirements of "experience."

\section{A.}

As Bickel stresses, however, this tension assumes a significantly greater dimension with the Supreme Court. In large part, the source of this additional dimension is to be found in what Bickel refers to as "The Mystic Function" of the Court; ${ }^{238}$ the sense in which the Court, because it "is seen as a continuum," because "[i]t is never, like other institutions, renewed at a single stroke," serves "to concretize the symbol of the Constitution," which, for our society, serves as "the symbol of nationhood, of continuity, of unity and common purpose." ${ }^{\text {"239 }}$ One of the consequences of being cast in a symbolic role-the need to assume a stance that can be apprehended by the public in terms of moral norms-has been evocatively portrayed by Dean Manning:

To the extent that our politics partake of the nature of a Morality Play, they have inevitably required, and generated, a set of theatrical conventions as arbitrary, and as acceptable, as those of any dramatic form. The vocabulary of our politics conforms to its role as a national Morality drama. That vocabulary is formal, dogmatic, simplified, symbolic, repetitive, and goal-setting; it is not descriptive and must not be thought of as being descriptive. And the actors in the political drama must, as in epic drama, appear as more than life-size, establishing, declaring, and

237. A. BICKEL, supra note 206 , at 173 .

238. Id. at 29-33.

239. Id. at 3 I. 
appearing to live in accordance with, standards that are not of this world. We therefore demand ultimate moral pronouncements from our parties and our offcials. We beatify or apotheosize our former Presidents, feeling the need for unifying national moral norms and having no national established church to do the job or to produce national saints. ${ }^{240}$

Manning, in the passage quoted, was considering the rhetoric of United States political campaigns and offering an explanation for the imposition upon our government officials of requirements for the divestment of holdings in commercial enterprises that go far beyond the purported necessity to avoid conflicts of interest, and that serve in fact to deprive government of so large a proportion of the society's administrative and technological talent that the effective formulation and implementation of national policy may seriously be threatened. Insofar as the Court also has a symbolic role to play in our society, however, it too is subject to the mandate of "establishing, declaring, and appearing to live in accordance with, standards that are not of this world." In the case of the Court, those standards require the maintenance of an appearance not only of incorruptibility-which the society largely, and correctly, takes for granted-but also of adherence to principle, to "logic," and to neutrality.

The impact of such requirements is most clearly apparent in the rhetoric of decision, in what was referred to in part III-F as matters of "phrasing." When a dissent characterizes the majority's disposition as an impermissible "amending of the Constitution," for example, the rhetoric serves precisely the same function as an accusation by the minority in the House that the majority are "employing steamroller tactics" or "playing partisan politics." The dissenting judge is fully aware, of course, that any judicial interpretation of a constitutional principle involves a pro tanto "amendment" of the Constitution, just as the House minority knows full well that "partisan politics" are an integral part of the legislative process and that the majority's electoral mandate involves, in part, a commitment to enact certain policies and, if necessary, to use "steamroller tactics."

Neither the dissenting judge nor the House minority, then, is suffering from any illusions concerning the nature of the judicial or legislative process. What they are doing is adverting to the existence of certain overriding goals that those processes are expected to fulfill: stability and continuity, in the case of judicial interpretation of the Constitution, and the need for compromising competing interests and for giving some recognition to the legitimate demands of the minority party, in the case of the legislative process. In both instances, therefore, the appeal is to the symbols in terms of which those overriding goals are expressed: an unchanging Constitution,

240. Manning, The Purity Potlatch: An Essay on Conflicts of Interest, American Government, and Moral Escalation, 24 FED. B.J. 239, 243 (I964). 
whose meaning is clear and accessible to all, and which is simply applied by the judiciary to the cases that are brought before it; and a legislative process that represents the work, not of members of political parties or agents of interest groups, but of statesmen whose sole concern is the attainment of the national good.

Another example of the impact of the requirement that symbolic appearances be maintained is to be found in the Court's refusal to assign significance to changes in the policymaking personnel of an administrative agency, the refusal to treat such changes as a reason for either more or less stringent scrutiny of that agency's decisions. The suggestion offered is not, of course, that the Court ought to scrutinize an agency's decisions more closely because individual Justices personally dislike or distrust the policymaking members of the agency. No court could long survive public awareness of such flouting of the ideal of dispassionate inquiry to which our judiciary is held. But assume that the legislative history of a given statute indicates that it was to be interpreted in a certain fashion, and that both the administrative agency charged with its implementation and the Court had agreed on the propriety of that mode of interpretation over a period of years. And assume further a change in agency personnel resulting from the entry into office of an administration out of sympathy with the aims of the statute (does the NLRB under Eisenhower's administration at least partially fit this description?). Why, under such circumstances, does not the change in personnel provide a proper occasion for a judicial announcement that that agency's decisions will henceforth be subject to more stringent scrutiny?

The answer, it is suggested, is not that the Court is under any illusion as to the unimportance of the political persuasion of agency personnel in determining the spirit in which congressional statutes are implemented; a Court that suffered from such an illusion would have to regard as meaningless the many statutory provisions that specify the political composition of the policymaking arms of administrative agencies. The crucial point is, rather, that the Court is charged with the function of upholding the symbol of an evenhanded Government, characterized by continuity of policy and devoted to the interests of the nation as a whole rather than to the attainment of parochial, partisan goals. And that ideal, symbolized by the belief that we are ruled by a "government of laws, not men," would be seriously compromised by overt recognition of the fact that a change in party, even without an accompanying change in legislative mandates, can nevertheless result in a change in law.

Recognition of this consequence of the Court's symbolic role severely limits the applicability of any requirement of "candor" in measuring that institution's achievements. Shapiro's fears concerning the possibility of "the 
Court's loss of that precious political asset, a reputation for candor," are based on the premises that the public looks at opinions, not results, and that it demands of those opinions the utmost candor concerning the bases of decision. The short answer is that matters are far more complex than that. To begin with, it is a far more likely hypothesis, as we have seen, that the public responds as much to results, to the outcome of a given decision, as to the rhetoric contained in the opinion. ${ }^{241}$ Even more important, however, are the complicating factors introduced by the Court's symbolic function.

It is true, of course, that there exist severe limits on the extent to which the content of symbols such as those considered above are taken literally by the public. The public is aware, and to some extent accepts as inevitable, that, for example, the staffing of many governmental offices is dictated by narrowly political considerations; that our government is, in a sense-as the statutory provisions specifying the political composition of administrative agencies attest-a government of men as much as of laws. But that fact alone does not entail the proposition that an increase in public sophistication will, or ought to, lead to a public willingness to accept a rhetoric that substitutes greater candor concerning the processes by which the polity is governed for continued adherence to the symbols cherished by the society.

In some cases, where the conflict between symbol and reality is particularly acute, and where continued adherence to symbolic rhetoric would seriously interfere with the efficient performance of the workaday governmental task, such a result may well follow. But the point remains that continued adherence to the symbolic content of government is not just a matter of "keeping up appearances," that the overriding social goals embodied in those symbols have both meaning and importance. It is thus of the highest importance that our legislators be reminded constantly of their obligation to be more than members of a political party or agents of an interest group, and that our judges display a proper regard for the traditional wisdom contained in precedents and the social utility of continuing adherence to established patterns of social organization.

But these requirements are only half of the story of government, for the work of this world, the world in which the symbols are only partially and sometimes operative, also urgently requires doing. If society is to continue to function efficiently, in other words, parochial interests must continue to be represented effectively in the legislative process; and political parties, despite the fact that they are unsanctioned by any mention in the constitutional text, represent the means developed by our polity for fulfilling this task. Similarly, a Court concerned exclusively with adherence to the "logic" of precedent could not long succeed in the task of keeping relevant to 
present-day social needs a constitutional text phrased in the language of I8th-century concerns and concepts.

That task, it might be argued, is properly performed, not by the Court, but by the people of the society through the democratic process of amending the Constitution. Two factors, however, militate against such a conclusion. First, the cumbersome and complicated machinery provided for amendment casts serious doubt on both the efficacy and the democratic nature of reliance on this process, if by democratic we mean responsive to the majority will. More importantly, a Constitution that had been amended, rather than judicially interpreted, in the majority of instances in which such interpretation was required to maintain it as a continuingly relevant document, would by that very fact cease effectively to serve as the symbol of continuity that represents its greatest contribution to the continuing stability of our society. ${ }^{242}$ The short of the matter, then, is that the Court's symbolic function is best fulfilled in terms of what Dean Manning designates a "dramatic form" and that our society requires, from that dramatic form, a far more complicated mixture of appearance and reality than Shapiro's insistence on candor would allow for.

It is precisely because we entrust them with so important and complex a function that being a Supreme Court Justice, rather than a law professor, regularly appears in public opinion polls as the most desirable occupation in our society. Law professors tend to be more skilled than many Justices in the "logic" of the law and would no doubt be more capable, in many instances, of meeting Shapiro's criterion of candor in opinion writing. But the task that we entrust to our Justices requires the political sensitivity of the statesman as well as the doctrinal skills of the lawyer. It is for this reason that Justices are selected by means of a political appointment process rather than by a nationwide system of examinations, and that the high degree of rationality required of Justices by Bickel, ${ }^{243}$ even if it were possible of attainment, would in the end prove to be an insufficient criterion.

The objection might be taken that the description given above represents an apotheosis of the role of a Supreme Court Justice that no actual incumbent could hope to achieve. But such an objection confuses a job description with an assessment of the degree of skill required to perform a given task satisfactorily. No marriage is perfect, and precious few are great, but the fact that any marriage would disintegrate under the stress of an insistent demand for complete candor is nevertheless sufficient to convince us that intellectual honesty is inadequate as the sole criterion for selection of a marital partner.

242. See, e.g., A. Bicked, Politics and the Warren Court I55 (I965).

243. See text following note 132 supra. 
Similarly, in the case of the Court, we cannot legitimately withhold our consent from its activities until we become convinced that the nine men who staff it are capable of performing perfectly. We need only agree that there exists a role that must be performed, and that our selection process for filling that role is as satisfactory as possible. After that, as in all human endeavors, we can only ask that the nine men we have chosen do the very best they can. In government as in marriage, there comes a point where consent is based on trust. It is precisely at such a point that the possibility of abuse of power is greatest. But that, of course, is the meaning of trust, the meaning that ultimately gives content to the "Morality Play."

B.

Even if one accepts these consequences of the Court's symbolic function, however, the question remains how the Court's power is to be confined within its legitimate boundaries. As we have seen, it was this concern, based on his view that the Court during the I930's was making decisions properly entrusted to Congress, that underlay Mr. Justice Black's insistence that the Court rely on the "logic" of constitutional principles rather than the "experience" of the common law.

To a considerable extent, Shapiro simply ignores the question thus posed by Black. "[I]n the free speech area," for example, Shapiro argues that "the Supreme Court represents some interest groups while other government agencies represent others." ${ }^{244}$ Consequently, "[ $\left.t\right]$ he Supreme Court can actually contribute to greater democracy by vigorously furthering the interests of its groups, which are not being protected by other parts of the government, so that all interests in our society may have a voice in making policy decisions." impact of a decision by the Court and one by Congress are the same; whereas the problems posed by judicial review, not only for Black but also for Hand and Wechsler, inhere precisely in the finality embodied in a finding of unconstitutionality, in the fact that such a holding, unlike legislative action, largely forecloses further action by other agencies of government representing other interest groups.

Both Congress in passing a statute and the Court in upholding its validity are, after all, passing judgment on the same statute. If all that is involved is the same type of policy decision made by bodies whose difference is simply that they represent different interest groups, on what basis is Congress compelled to respect the decisions of the Court? Shapiro himself betrays awareness of this point when he argues that Congress cannot itself make final determinations of the constitutionality of measures that argu-

244. M. Shapiro, Freedom of Speech: The Supreme Court and Judicial Review 2 (ig66).

245. Id. See also text accompanying notes $14-16$ supra. 
ably infringe first amendment rights because its deliberations focus too much on the "marginal adjustments and compromises" of the legislative process. ${ }^{246}$ Yet his analysis of the work of the Court would make it simply one more participant in that process.

If the Court's decisions are entitled to a special sort of deference denied to acts of Congress, there must be some set of differences between the two institutions that can account for this phenomenon-a set of differences ignored in Shapiro's analysis. The best starting point for delineation of those differences is Shapiro's description of Congress as a social system in which participants can efficiently attain their legislative goals only by minimizing conflict within the system, by helping to preserve that system through cooperation with the floor leadership and heads of committees. ${ }^{247}$ Contrast with this the degree of independence from such institutional pressures enjoyed by Supreme Court Justices: the absence of any committee system; the freedom from party discipline; and the very considerable freedom, afforded by life tenure, even from any analogue to constituent pressure, all of which ensure that decisions of the Court represent neither attempts to preserve a given social system nor the result of "marginal adjustments and compromises" among competing power centers, but rather the expression of what the individual Justices collectively interpret the constitutional mandate to be.

Equally important in defining the institutional differences between Congress and the Court is the greater importance of craft pressures in connection with the latter's work-the need to present an adequate justification for the result reached. This factor is based in considerable part on the tradition of scholarly criticism of the Court's work, which enforces demands of intellectual coherence on the rationale offered for decision. ${ }^{248} \mathrm{But}$ it rests also on the procedures that the Court has adopted from the common law: the setting forth of the rationale for decision in an opinion open to public scrutiny, and the acceptance of the limitation that, with the narrowly confined exception of judicial notice, a decision is to be arrived at, and support for its rationale obtained, exclusively from the evidence in the record before the Court. It is ultimately these differences that justify the conclusion that the majority of constitutional issues are better resolved through the processes of the Court than through the processes of Congress, and that the Court's resolution of those issues is properly entitled to a degree of deference and finality not normally accorded to acts of Congress.

It is therefore not sufficient to determine, when deciding whether or not the Court has acted properly in taking cognizance of a given issue, that the

248. Cf. A. BICKEL, supra note 206 , at 5I-55. 
other branches of the government have long disregarded, and are likely to continue to disregard, the problems involved. It is necessary further to determine whether the issue is one with which the Court can deal while continuing to satisfy both craft pressures and the needs of its symbolic role-the complex and often conflicting demands for adherence to logic, to neutrality, and to experience that our society makes upon it. It is this second step that Shapiro, in his analysis of the Reapportionment Cases, ${ }^{248}$ fails to take.

Shapiro approves of the decision in Baker v. Carr ${ }^{250}$ precisely on the basis that a serious problem existed that no other agency of government was capable of dealing with. ${ }^{251}$ What Shapiro disapproves are the decisions following Baker, the Reapportionment Cases, which established the "one man, one vote" principle. Shapiro's objection is not, of course, that the "one man, one vote" principle lacks neutrality. Quite the contrary, Shapiro sees that principle as embodying all of the worst faults that result from an insistence on a relentlessly generalizable rule of decision, ${ }^{252}$ and his penetrating survey of the complex and unresolved issues in political philosophy raised by a democratic form of government ${ }^{253}$ makes clear his conviction that "one man, one vote" constitutes an oversimplified political slogan rather than a desirable solution to the problems of malapportionment:

Majoritarian elections and representative government are not ends or values in themselves but are at best instrumental values, "good" only to the extent that they contribute to the goals of liberal democracy. Democratic theorists cannot simply say-and American democratic theory has never consistently held—that "one man, one vote" majority rule is "good." They can say only that "one man, one vote" majority rule is good so far and only so far as it contributes to maximum individual political equality and freedom. No democratic theorist can state flatly and finally just how much of the "one man, one vote" principle should be introduced into American politics. He can only make rough adjustments based on estimates of the political consequences.

It is exactly this approach that the Court took in Baker when it, in effect, said that Americans have reached a consensus that a proportion of eighteen to one is a hindrance to democracy. Neither they nor we, however, can say that a one-to-one proportion always maximizes democracy. In Baker, the Court stated the American balance between "Madisonian" and "populistic" democracy and avoided binding itself to precise standards of representation, any one of which would be theoretically incorrect because democratic theory does not contain any such precise standards.

It is at this point that the Court as political theorist might have become Court

249. Reynolds v. Sims, 377 U.S. 533 (1964); WMCA, Inc. v. Lomenzo, 377 U.S. 633 (I964); Maryland Comm. for Fair Representation v. Tawes, 377 U.S. 656 (x964); Davis v. Mann, 377 U.S. 678 (1964); Roman v. Sincock, 377 U.S. 695 (1964); Lucas v. Forty-Fourth Gen. Assembly, 377 U.S. $713(1964)$.

250. 369 U.S. $x 86$ (I962).

25I. M. Shapiro, Law and Politics in the Supreme Court: New Approaches to Political JURISPRUDENCE 233-34, 236 (1964).

252. See id. at $232-33,236$.

253. See id. at $2 \times 6-32$. 
as political scientist, analyzing the actual operation of the political forces around it. For once the democratic theorist recognizes that electoral equality is not equivalent to political equality or freedom but is simply a means that sometimes contributes to and sometimes conflicts with these ends, he must decide when, where, and how much electoral equality should be added to or subtracted from the political system in which he operates, in order to make it more democratic. Given the complexity of contemporary American politics, such assessments are always difficult, but one thing is fairly certain. Whatever the assessments, they are likely to suggest delicate adjustments rather than sledge-hammer blows. It seems highly unlikely that either a continuation of the present crazy quilt of malapportionment or introduction of total and immediate equalization of votes will yield a democratically ideal result. The Baker decision allowed the Supreme Court to make its own case-by-case assessment of the political balance in any given state and to fit its remedies to the situations it found. When it is recalled that the processes of group politics may give to members of certain groups far greater political influence than to others and that the relative strength of various groups is markedly affected by the geographic distributions of population, resources, industries, and so forthdistributions that vary markedly from state to state-whoever attempts to achieve greater equality must be prepared to make differing adjustments in differing areas. $^{254}$

Shapiro then shifts his focus to those decisions following Baker-Gray v. Sanders, ${ }^{255}$ Wesberry v. Sanders, ${ }^{256}$ and the Reapportionment Cases-the decisions that resulted in the "one man, one vote" formulation:

The new decisions fundamentally ignore all that we have learned about the group nature of politics. By adopting the most simplistic view of the political process, and particularly of the process of representation, the Court equates the electoral and the political processes and thinks to assure each citizen "equal protection of the laws" in the political sphere by giving each citizen a vote equal to every other's. I have tried to show earlier that such a position glosses over or ignores the basic paradox hidden behind the notion of government by the people and mistakes an imperfect expedient, majority voting, for the essence of democracy. . . . A vision of the political process as no more than the electoral process and of each citizen as exercising his whole political power in the individual act of voting cannot properly serve even the most populistic philosophy. For in the complex politics of group bargaining and shifting temporary majorities that we actually have in the United States, inequalities in voting strength may contribute in the over-all equality of all participants in the political process as a whole. Blanket and blind enforcement of electoral equality will only decrease the political inequalities in some states at the cost of increasing them in others. The result of the Court's new rulings in terms of real political equality will be largely random. In the end they may achieve somewhat greater over-all equality but only because the sum of new equalities will exceed the sum of new inequalities. Viewed as an attempt actually to contribute to greater political equality in the United States, rather than simply as a philosophical editorial, the Court's new position is little more than a random stab. 257 
Shapiro's view of the proper role of the Court in the Reapportionment Cases is echoed in Mr. Justice Stewart's dissent from those decisions: ${ }^{258}$

Representative government is a process of accommodating group interests through democratic institutional arrangements. Its function is to channel the numerous opinions, interests, and abilities of the people of a State into the making of the State's public policy. Appropriate legislative apportionment, therefore, should ideally be designed to insure effective representation in the State's legislature, in cooperation with other organs of political power, of the various groups and interests making up the electorate. In practice, of course, this ideal is approximated in the particular apportionment system of any State by a realistic accommodation of the diverse and often conflicting political forces operating within the State.

I do not pretend to any specialized knowledge of the myriad of individual characteristics of the several States, beyond the records in the cases before us today. But I do know enough to be aware that a system of legislative apportionment which might be best for South Dakota, might be unwise for Hawaii with its many islands, or Michigan with its Northern Peninsula. I do know enough to realize that Montana with its vast distances is not Rhode Island with its heavy concentrations of people. I do know enough to be aware of the great variations among the several States in their historic manner of distributing legislative power-of the Governors' Councils in New England, of the broad powers of initiative and referendum retained in some States by the people, of the legislative power which some States give to their Governors, by the right of veto or otherwise, of the widely autonomous home rule which many States give to their cities. The Court today declines to give any recognition to these considerations and countless others, tangible and intangible, in holding unconstitutional the particular systems of legislative apportionment which these States have chosen. Instead, the Court says that the requirements of the Equal Protection Clause can be met in any State only by the uncritical, simplistic, and heavy-handed application of sixth-grade arithmetic.

The fact is, of course, that population factors must often to some degree be subordinated in devising a legislative apportionment plan which is to achieve the important goal of ensuring a fair, effective, and balanced representation of the regional, social, and economic interests within a State. And the further fact is that throughout our history the apportionments of State Legislatures have reflected the strongly felt American tradition that the public interest is composed of many diverse interests, and that in the long run it can better be expressed by a medley of component voices than by the majority's monolithic command. What constitutes a rational plan reasonably designed to achieve this objective will vary from State to State, since each State is unique, in terms of topography, geography, demography, history, heterogeneity and concentration of population, variety of social and economic interests, and in the operation and interrelation of its political institutions. But so long as a State's apportionment plan reasonably achieves, in the light

258. Justice Stewart's dissenting opinion in the Reapportionment Cases appears in 377 U.S. at 744. The dissent applied to Lucas v. Forty-Fourth Gen. Assembly, 377 U.S. 713 (1964), and WMCA, Inc. v. Lomenzo, 377 U.S. 633 (I964). In the other cases he did not dissent, but issued separate opinions stating either that the legislative apportionment in issue was irrational or (in Maryland Comm. for Fair Representation $v$. Tawes) that the case should be remanded for a determination of whether the "Maryland apportionment "could be shown systematically to prevent ultimate effective majority rule." " 377 U.S. at 677 . 
of the State's own characteristics, effective and balanced representation of all substantial interests, without sacrificing the principle of effective majority rule, that plan cannot be considered irrational. ${ }^{259}$

As the above quotations indicate, Stewart's interpretation of the requirements of the equal protection clause in apportionment cases is that the clause bars arbitrariness and systematic frustration of the will of the majority, ${ }^{260}$ not that it mandates absolute equality. Such an interpretation is supportable by reference to both what the Court had said in Baker ${ }^{201}$ and the equal protection doctrine contained in decisions applicable to other than apportionment situations. ${ }^{262}$ If, in addition to these virtues, Stewart's position also embodies a superior grasp of the principles of political science and political philosophy, why did the Court refuse to adopt it?

The answer to that question is surely not that the factors involved are inherently too complex for judicial analysis. That apportionment cases involve a formidable degree of complexity is undeniable, but the Court has long dealt with the complexities inherent in fields such as antitrust, and there is no reason to believe that the Court would be less successful at analyzing a given reapportionment problem than will the Governors' commissions and legislative committees presently undertaking this task. The answer is to be found, rather, in Shapiro's insistence that the Court examine "more than the electoral process" in Stewart's view that what must be considered is whether "a realistic accommodation of the diverse and often conflicting political forces operating within the State" has been achieved.

What both Stewart and Shapiro would require the Court to do in apportionment cases is to examine the realities of the distribution of political power within the State-the existence of voting blocs, the degree of party control over voters and officials, the position of the mass media, and the extent of financial backing available to the various factions, to mention only a few of the crucial inquiries. In dissenting from the invalidation of New York's apportionment, ${ }^{263}$ for example, Stewart quotes Elihu Root's remarks to the New York constitutional convention of 1894 , justifying the giving of fewer seats to New York City than a "one man, one vote" rule would require:

The question is whether thirty separate centers of 38,606 each scattered over the country are to be compared upon the basis of absolute numerical equality with one center of thirty times 38,606 in one city, with all the multiplications of power that comes [sic] from representing a single interest, standing together on all measures

259. Lucas v. Forty-Fourth Gen. Assembly, 377 U.S. 713, 749-5I (1964) (dissenting opinion) (footnote omitted).

260. See id. at 753-54.

26r. See M. Shapiro, supra note 25I, at 242-43.

262. See Lucas v. Forty-Fourth Gen. Assembly, 377 U.S. 713, 75I-53 (I964) (dissenting opinion).

263. WMCA, Inc. v. Lomenzo, 377 U.S. 633 (I964); see note 258 supra. 
against a scattered and disunited representation from the thirty widely separated single centers of 38,606 . Thirty men from one place owing their allegiance to one political organization, representing the interest of one community, voting together, acting together solidly; why, they are worth double the scattered elements of power coming from hundreds of miles apart. ${ }^{264}$

Whether or not it is correct to assume that the representatives of a large city are under pressure to represent only a single, homogenous interest, the quotation makes crystal clear that the formula espoused by Stewart and Shapiro would indeed require the Court to canvass the actual workings of the floor leadership in the legislative branches, the mechanisms of party control not only over voters and the city government but also over elected representatives-in short, the details of the petty corruption and networks of personal influence that all too often constitute crucial sources of power in municipal politics. Given the Court's institutional arrangements, however, it could investigate these matters only by requiring lower courts to build records on these issues. Is this a demand we can reasonably make of our courts? Even assuming that the evidence was available and would be forthcoming, is it likely that our society could accept, as a steady diet, the spectacle of the judiciary solemnly ruling on the accuracy of a political boss's testimony concerning the sources of his power over voters and the degree of control that he exercised over elected officials?

If the analysis, adumbrated earlier, of the function performed by political rhetoric has any validity whatsoever, the answer must be in the negative. The issue is not that the almost imperceptible gradations such investigations would reveal might go far toward undermining the neutrality of the principle being applied. The decisive point is, rather, that the content of the records that would necessarily have to be made, the image of our politics that the Court would be projecting, would be so totally incompatible with the content of the "Morality Play" as seriously to compromise the symbolic role not only of the judiciary ${ }^{265}$ but primarily of the political system that was being surveyed.

26.4. 3 Revised Record of the Constitutional Convention of the State of New York i215 (1900), qusoted in 377 U.S. at 764 .

265. Cf. Mr. Justice Frankfurter, dissenting, in Baker v. Carr: "Manifestly, the Equal Protection Clause supplies no clearer guide for judicial examination of apportionment methods than would the Guarantee Clause itself. Apportionment, by its character, is a subject of extraordinary complexity, involving-even after the fundamental theoretical issues concerning what is to be represented in a representative legislature have been fought out or compromised-considerations of geography, demography, electoral convenience, economic and social cohesions or divergencies among particular local groups, communications, the practical effects of political institutions like the lobby and the city machine, ancient traditions and ties of settled usage, respect for proven incumbents of long experience and senior status, mathematical mechanics, censuses compiling relevant data, and a host of others. Legislative responses throughout the country to the reapportionment demands of the I960 Census have glaringly confirmed that these are not factors that lend themselves to evaluations of a nature that are the staple of judicial determinations or for which judges are equipped to adjudicate by legal training or experience or native wit. And this is the more so true because in every strand of this complicated, intricate web of values meet the contending forces of partisan politics. The practical significance of apportionment is that the next election results may differ because of it. Apportionment battles are 
The Court cannot, in Bickel's terms, legitimate the politics of, for example, one-party rule by basing a constitutional decision on firsthand testimony concerning its operations. Nor could evidence consisting solely of charts, graphs, electoral statistics, and the testimony of expert witnesses meet the requirements of the Stewart and Shapiro formulas, which insist that apportionment involves "more than the electoral process" and that the proper inquiry must consist of a comprehensive analysis of the distribution of political power throughout the state. Given that quest, resort to the testimony of political-power holders concerning the existence of informal channels of power seems well-nigh unavoidable.

It will not do, therefore, to approve the decision in Baker v. Carr and then to disavow the principle arrived at in the Reapportionment Cases, for the institutional needs of the Court and the interplay between the demands made upon it by its symbolic function and the requirement that decisions be based on evidence contained in the record inevitably resulted in the adoption of a standard that does not require involvement of the judiciary in the spectacle portrayed above-in short, "one man, one vote." The significant question in the apportionment controversy is the one that both Stewart and Shapiro ignore, the analogue to the question Wechsler must be taken to have answered in the negative in assessing the Brown decision: ${ }^{28 B}$ Whether, given the fact that a "one man, one vote" standard

overwhelmingly party or intra-party contests. It will add a virulent source of friction and tension in federal-state relations to embroil the federal judiciary in them." 369 U.S. at 323-24 (footnotes omitted).

266. See text accompanying note 96 supra.

The question as posed here is, however, subject to several qualifications. First, adoption of a "one man, one vote" standard by no means answers the question of the number of situations to which the Court will apply such a standard. Thus, as both Bickel and Wechsler implicitly predicted, the "colorblind" standard that underlay Brown has not been applied to "benign quota" situations. And similar limitations have already been imposed by the Court on the applicability of the "one man, one vote" standard. See, e.g., Sailors v. Board of Educ., 387 U.S. I05 (I967) ("one man, one vote" standard irrelevant to local nonlegislative school officials chosen by essentially appointive process); Fortson v. Morris, 385 U.S. 23 I (1966) (state legislature not disqualified, by reason of malapportionment, from voting in runoff election for governor where previously held that legislature had until 1968 to reapportion). Nor does adoption of such a standard, even apart from the possibility of permissible degrees of variation from an ideal apportionment, bar the utilization of devices such as gerrymanders for accommodating many of the same political pressures that had previously resulted in malapportionment. See In re Apportionment of Mich. Legislature, 376 Mich. 410, 137 N.W.2d 495 (1965), 376 Mich. 4 IO, 138 N.W.2d I6 (1965), 377 Mich. 396, I40 N.W.2d 436, appeal dismissed stib nom. Badgley v. Hare, 385 U.S. xx4 (1966) (per curiam) (want of substantial federal question); Neal, Baker v. Carr: Politics in Search of Law, I962 S. CT. REv. 252, 277-78.

There is, finally, the question whether, given the inevitability of a "one man, one vote" standard, the Baker opinion should have "candidly" canvassed the jurisdictional issue in these terms. To do so would have required the Court to discount several possibilities that appeared at least feasible, if not likely, at the time the decision was rendered: the possibility that the analysis given in the text above was erroneous, and that some standard short of "one man, one vote" could have been developed; the possibility that litigation would proceed in such a fashion as to make it unnecessary for the Court at any early date to reach the issue of the ultimate standard to be applied, either because cases could be disposed of upon the basis of more limited issues, or because the state and lower federal courts would apply standards approximating "one man, one vote" without further guidance; and finally, the possibility that an aroused electorate would force state legislatures to undertake their own reapportionments, the possibility, in short, that further judicial intervention would not be required at all. History, of course, has seen none of these possibilities realized, and in this limited sense Shapiro's call for greater "candor" in Baker $v$. Carr seems on balance to be justified. The issue, however, was a good 
would have to be applied, the consequences of malapportionments were sufficiently serious that greater injury would have been done to the Court's prestige by a refusal to deal with them than by the public controversy that application of that standard aroused.

Shapiro's condemnation of the reapportionment and segregation decisions, like the insistence on candor that results in the coalescence of his assessments of the Court's work with those of the "modest," thus arises from his disregard of the institutional needs of the Court, a failure that seems all the more startling in the context of his insistence that the Court be viewed as a political institution. Our final inquiry must be, therefore, a search for the sources of that failure.

\section{VIII.}

The considerable interest demonstrated by legal scholars in the institutional structure of courts has been part of the search for limitations on judicial discretion. Much of the significant literature in this area is premised on the hypothesis that analysis of the institutional role and capacity of the judiciary will make possible the formulation of guidelines in terms of which courts can be confined within their legitimate sphere of authority. ${ }^{267}$ It is this quest, as we have seen, that underlies Justice Black's prescription of logic rather than experience in constitutional adjudication and that makes so important the question insistently raised by Black and ignored by Shapiro of the existence of standards by which the decisions that are properly Congress' can be distinguished from those properly the Court's. ${ }^{268}$ Bickel's mediating devices represent one response to this dilemma, and their derivation from the doctrines of "lawyer's law" on which Shapiro also focuses ${ }^{209}$ underlines the extent to which the lawyer, in this instance, has displayed a far more sensitive regard for institutional considerations than has the political scientist.

The most important clue to the origins of this anomaly is provided by the fact that Shapiro's focus, unlike Bickel's, is not on the activity of the Court as such, but rather exclusively on the interaction of the Court with other agencies of government. This difference is clearly apparent, for example, in the argument offered by Shapiro to justify his central postulate, the propriety of treating courts as political institutions:

That courts are political agencies is self-evident. They are part of government, they make public policy, and they are an integral part of the law-making and enforce-

deal more complicated than Shapiro suggests, precisely because of the existence of those institutional demands that an insistence on "candor" necessarily overlooks.

267. See, e.g., H.M. Hart \& A. Sacks, The Legal. Process (tent. ed. i958); H.M. Hart \& H. WeChsLeR, The Federal Courts AND the Federal SysteM (1953); K. Lleweliyn, supra note 225, at I9-5I; H. WELIINGTON, LABOR AND THE LEGAL SYSTEMI (tent. typescript ed. 1967).

268. See text accompanying note 244 supra.

269. See text accompanying notes $4-5$ supra. 
ment process which is the central focus of political activity. If legislatures are political and executives are political, then courts must be political since all three are inextricably bound together in the process of making law, and each sometimes performs the functions that each of the others performs at other times. ${ }^{270}$

Such a view, as we have seen, offers many valuable insights, but it utterly fails to provide a framework in terms of which boundaries among the various political institutions can be delineated; and precisely that, as the opinions of Black and the scholarly work of Wechsler and Bickel testify, is the important task.

Shapiro's focus on the process rather than the actor, on interactions within a given system rather than on the component parts of that system, is not, however, peculiar to his analysis of the work of the Court. It is evident in many recent studies by political scientists, including, for example, Professor Robert Dahl's pathbreaking exploration of the distribution of political power in the New Haven municipal setting, Who Governs? ${ }^{271}$ As is stressed in the companion volume, Professor Nelson Polsby's Community Power and Political Theory, ${ }^{272}$ the New Haven study had a theoretical as well as a descriptive function: that of demonstrating the extent to which power in our cities is decentralized and, consequently, of correcting the conclusions of those Polsby refers to as "social stratification" theorists to the effect that communities are ruled by a single "power elite."273

The method used in Who Governs? is to identify a number of important political decisions and the participants in them, to study the behavior of those participants in the course of decisionmaking, and to analyze the benefits and disadvantages accruing to various participants as a result of the outcomes that ensued. What Dahl found was that no single social or economic group either controlled the decisionmaking process or regularly benefited from the results reached. Further, there was remarkably little overlap among the participants in the various New Haven decisions studied by $\mathrm{Dahl} .^{274}$ In connection with the urban renewal program, for example, although the mayor created a citizens' action commission composed of representatives of the economic elite, Dahl's study revealed that the commission almost never initiated any proposal, nor vetoed or altered one put before it by the mayor. ${ }^{275}$ Dahl concluded, therefore, that power in New Haven is held by constantly shifting, issue-oriented coalitions, with consid-

270. M. Shapiro, Stability and Change in Judicial Decision-Making: Incrementalism or Stare Decisis?, 2 LAw IN TRANSITION Q. I34 (1965). For a similar view see Dahl, Decision-Making in a Democracy: The Sutpreme Court as a National Policy-Maker, 6 J. Pob. L. 279 (I957).

27x. R. DaHL, Who Governs? Democracy and Power in aN AMIERICaN City (I96r).

272. N. Polsby, Comanuntry Power and Poltmcal Theory ( 1963 ).

273. See id. at 69-97.

274. R. DAHL, stspra note 27I, at I75.

275. Id. at I3I. 
erable scope being given to a vigorous mayor determined to exploit his political resources to the utmost.

The primary difficulty with Who Governs? as an analysis of the existing distribution of power is its assumption that the decisions canvassed represented conflicts sufficiently serious to force all potentially affected powerholders to mobilize their resources in the hopes of obtaining a favorable outcome. As Dahl himself recognizes, however, in connection with two of the three areas he studied-public schools and political nominationsit can convincingly be argued that the economic and social elite, which lives primarily in the suburbs, is largely indifferent to possible outcomes. ${ }^{278}$ Moreover, in connection with the third area studied, that of urban renewal, it is far from clear that New Haven's economic elite saw its interests as being significantly threatened rather than advanced. And even if members of the elite were aware that the urban renewal program had certain implications that ran counter to their interests, it nevertheless remains possible that those implications were perceived as being outweighed by the advantages accruing to them.

The important question, then, the question that Dahl never asks in connection with, for example, the power of the citizens' action commission, is whether that commission failed to assert itself because it was powerless or because, given the program as proposed by the mayor, it was indifferent to further modifications. The inquiry is whether the commission's failure to oppose the mayor's proposals represents an index of powerlessness or can be explained, rather, by the hypothesis that the mayor never proposed to the commission anything that he thought that body might reject. If the latter hypothesis is true, and the mayor would in fact have formulated different proposals had he thought the commission would accept them, who then holds power in New Haven?

Such a question ultimately raises the issue of the possible priorities of an elite. Dahl's method of investigation could reveal the true distribution of power in New Haven only if every possible elite assigned the highest priority to never suffering any disadvantage whatsoever from the outcome of any decision reached in any area of New Haven life. Given that postulate, the fact that Dahl's studies reveal the absence of elite participation in certain decisions and the existence of outcomes that to some extent disadvantage the elite would indeed indicate a lack of power on their part. The more likely hypothesis, however, one that Dahl himself apparently accepts, ${ }^{277}$ is that members of the elite will not feel compelled even to enter the arena studied by Dahl unless they perceive what they regard as important interests to be threatened. The difficulty is that Dahl resolutely refuses

276. See id. at $70-7$ r.

277. See id. at $224-25,237-38,270-301$. 
to address the difference between those conflicts that an elite would perceive as both significant and threatening and those to which it would remain relatively indifferent. ${ }^{278}$

None of the above, of course, purports to deny the significant contribution made by Who Governs? to the study of the functioning of political power in local communities. As Dahl convincingly demonstrates, the ways in which such power is exercised are far more complicated than the social-stratification theorists would have us believe. But that demonstration, as we have seen, falls far short of embodying a convincing delineation of the actual distribution of power. The absence of a covert and all-encompassing network of influence that ensures elite participation in, and dictation of the outcome of, all New Haven decisions is not, after all, very startling news. Only the most ruthless and heavyhanded elite, or an elite fearing imminent loss of its power, would feel compelled to act in so assertive and undiscriminating a manner. In the end, therefore, rather than offering an analysis of the distribution of political power, what Who Governs? largely accomplishes is to supply a correct answer to an often irrelevant question.

In part, the objections advanced above to Dahl's methods can be epitomized as exemplifications of his failure to take into account what Professor Carl Friedrich first described as the rule of anticipated reactions: the hypothesis that much political behavior is governed by the actor's perceptions of, and adjustments for, the reactions he expects to be provoked by possible actions on his part. ${ }^{279}$ Thus, if the citizens' action commission did exercise any power in New Haven's urban renewal program, it did so exclusively by forcing the mayor to propose only those measures that would not conflict with the reactions he anticipated from the commission. The total absence of overt conflict between the mayor and the commission, however, means that such a hypothesis would be viable only on the assumption that the mayor's assessment of the commission's probable reaction was unfailingly accurate.

Given the mayor's political skill, such an assumption is not untenable, ${ }^{280}$ but the necessity for invoking it points up the major methodological problem inherent in the anticipated-reaction hypothesis: the extreme difficulty involved in obtaining data on the basis of which it can be either confirmed or disproved in any given situation. Dahl himself noted this diffeulty in connection with a study of influence ranking in the United States Senate; there he encountered a problem he called

278. For a similar and more detailed discussion of these objections to Dahl's method see Bachrach \&: Baratz, Two Faces of Power, 56 AM. PoL. Scr. REv. 947, 950-52 (1962).

279. See C. Friedrich, Constitutional Government and Politics: Nature and DevelopAEENT I 6-I8 (1937); Simon, Notes on the Observation and Meastrement of Political Power, I5 J. Pox. 500, 505-06 (I953).

280. See Bachrach \& Baratz, supra note 278, at 952 n.29. 
the problem of the chameleon. Suppose a Senator takes no prior position on any bill and always decides how to vote by guessing how the Senate majority will vote; then, if he is a perfect guesser, according to the ranking method used he will be placed in the highest rank. Our common sense tells us, however, that in this case it is the Senate that has power over the Senator, whereas the Senator has no influence on the votes of other Senators.

... In order to identify chameleon behavior and separate it from actual attempts at influence, one cannot rely on roll-calls. One needs observations of the behavior of Senators prior to the roll-calls. But if it is true, as I have been arguing, that observations of this kind are available only with great difficulty, rarely for past sessions, and probably never in large numbers, then in fact the data needed are not likely to exist. But if they do not exist for the Senate, for what institutions are they likely to exist? 281

We need not examine here the extent to which the absence of such data makes it impossible to reach judgments about who wields power in a given situation, although the existence of historians, whose trade consists of making such judgments, is persuasive evidence that the task is a possible one. Our primary concern is with a phenomenon that, although analogous to anticipated reactions, operates both more widely and less consciously-the phenomenon of the shared community expectation.

In connection with New Haven, Polsby makes explicit the impact of this phenomenon on the distribution of political power within the community:

Some, perhaps most, possible courses of action are never considered in community decision-making simply because they are inconceivable to the actors involved. No one seems ever to have seriously considered turning the privately owned New Haven Water Company over to the city, for example, although there seems to be no reason why this could not be done. The array of alternatives presented for community decision-making seems likely, then, to be determined by consideration [sic] very different from a rational canvassing of all technically feasible possibilities. What determines the agenda of alternatives within which community decision-making takes place?

There are several plausible answers to this question, but the current state of affairs seems to be centrally important in determining the future course of action. ... .

Dahl has suggested as a general principle that: "If A's goal requires a slight change or weak response from $B$, and C's goals require a great change or a strong response, then with equal resources, rate [sic] and efficiencies [of resource employment], $A$ is more likely to succeed than $C$. Or, to put it another way, $A$ can attain his political goals with less influence than $\mathrm{C}$ can. Thus, if A's goals fall well within 'political consensus' he may have to do little beyond maintaining the consensus; whereas if C's goals fall well outside the 'political consensus,' then for him to achieve his goals may require access to enormous resources."

. . . It is not enough . . . for an alternative to be technically feasible. It also

281. Dahl, The Concept of Power, 2 BeHuv. Sct. 201, 212-I4 (1957). 
must be politically palatable and relatively easy to accomplish; otherwise great amounts of influence have to be brought to bear with great skill and efficiency in order to secure its adoption. Conclusions that might be drawn from this are that the community agenda of alternatives is relatively insensitive to any but very great differences in the power of actors and that only influence differences of the greatest magnitude as between actors are likely to be reflected in changes in the alternatives presented to decision-makers. ${ }^{282}$

As exemplified by the quotation just given, investigators such as Dahl and Polsby typically devote little attention to ascertaining the origins of the "current state of affairs" or the content of the "community agenda of alternatives." This lack of attention is in part due precisely to the fact that the community agenda represents a shared set of expectations. In other words, because the agenda is the community's, because its content is not a source of conflict among groups within the community, the methods utilized by Dahl in Who Governs? are wholly inappropriate to the task of analyzing those origins or that content.

The contents of the agenda may of course-indeed, probably will-significantly favor one set of groups within the community. But as long as the disadvantaged groups do not disassociate themselves from that agenda, analysis of the conflict of interests thus created would require the postulate that the disadvantaged groups have a "real" interest that they are prevented from perceiving by their acceptance of the agenda. Such a postulate, however, because it involves making value judgments that cannot be correlated with the actual behavior of participants in the decisionmaking process, is extremely difficult to integrate into the conceptual structure underlying Who Governs?

Dahl's failure to explore the consequences of the existence of a community agenda is also at least partially due to a methodological problem analogous to that posed by the "chameleon." Thus, rejecting the suggestion that the power of a ruling elite might inhere precisely in the control that it exercises over the community consensus embodied in an agenda of alternatives and therefore that such control is inaccessible to an analysis of conflicts between the ruling elite and other groups, Dahl has argued that

either the consensus is perpetual and unbreakable, in which case there is no conceivable way of determining who is ruler and who is ruled. Or it is not. But if it is not, then there is some point in the process of forming opinions at which the one group will be seen to initiate and veto, while the rest merely respond. And we can only discover these points by an examination of a series of concrete cases where $k e y$ decisions are made: decisions on taxation and expenditures, subsidies, welfare programs, military policy, and so on. ${ }^{283}$

282. N. PoLSBY, stupra note 272 , at $133-35$ (italics in original) (footnotes omitted). in original). 
Two points need to be made concerning this theoretically unassailable proposition. First, the fact that the existence of the consensus benefits the elite does not provide a sufficient basis for assuming that the elite in some conscious sense controls or manipulates that consensus. The elite would presumably mobilize its resources in opposition to any attempt to change the consensus to its disadvantage, but as long as no such attempt occurs, as long as the consensus truly represents a shared set of community values, there is no reason to suppose that the elite's acceptance of those values is more self-conscious than their acceptance by any other group. Dahl's insistence on attacking only a model of an elite that actively manipulates the community consensus, rather than considering the possibility of an elite that is the passive beneficiary of the consensus, once again runs the risk of supplying a correct answer to an irrelevant question.

Second, and more important, there is the problem of the time scale. Dahl's assertion that unless there is a conflict concerning the community agenda there is no way to distinguish the rulers from the ruled is true. But such a conflict is most likely to arise over failures of the community consensus to shift in accordance with changes in economic and social conditions. Given a comfortably affluent society, such changes become apparent only over fairly long periods of time, and the resulting conflicts may therefore occur only near the end of such periods, when the disparity between the old consensus and the new social and economic reality is particularly great. The absence of conflict concerning the community agenda during any reasonably limited period of time does not, therefore, imply that such a conflict is not likely in the future. The question, to repeat, is always whether the time scale chosen was a sufficiently long one. In the case of Who Governs? no attempt is made to demonstrate that it was. ${ }^{284}$

Moreover, as Polsby explicitly notes, the existence of a community agenda of alternatives imposes stringent limitations upon the changes that can be introduced through the processes of community decisionmaking. As long as that agenda continues to benefit the elite, therefore-and if an elite exists at all it is presumably because the agenda does favor it-it seems reasonable to expect that the elite will remain largely indifferent to the outcomes of community decisions. The changes to which we would not expect it to remain indifferent, changes in the community agenda itself, are precisely those that Polsby and Dahl convincingly demonstrate to be the most difficult to bring about.

Polsby also accounts for the mechanism by means of which the community agenda limits the possible outcomes of community decisions-the fact that "some, perhaps most" outcomes "are inconceivable to the actors

284. For an analysis of the cognate problem that arises in connection with the anticipated-reaction hypothesis see Simon, supra note 279, at 505-06. 
involved." This internalization of the community agenda by the actors involved in community decisionmaking is not, of course, a phenomenon limited to municipalities. Dahl, for example, makes this argument:

If the military leaders of this country and their subordinates agreed that it was desirable, they could most assuredly establish a military dictatorship of the most overt sort; nor would they need the aid of leaders of business corporations or the executive branch of our government. But they have not set up such a dictatorship. For what is lacking are the premises I mentioned earlier, namely agreement on a key political alternative and some set of specific implementing actions. That is to say, a group may have a high potential for control and a low potential for unity. The actual political effectiveness of a group is a function of its potential for control and its potential for unity. Thus a group with a relatively low potential for control but a high potential for unity may be more politically effective than a group with a high potential for control but a low potential for unity. ${ }^{285}$

We have been spared a military dictatorship, then, because the military, in Dahl's terms, have "a low potential for unity," which is to say that they have not agreed "on a key political alternative and some set of specific implementing actions." The "key political alternative," however, must surely be the decision to set up a military dictatorship, and if this decision were made, our military organization would presumably be capable of producing plans outlining a "set of specific implementing actions." In the end, therefore, to say that we have not had a military dictatorship because the military have "a low potential for unity" seems to amount to saying that we have not had a military dictatorship because the military have not (yet) agreed among themselves that one ought to be imposed.

The important question must surely be why the military do not so agree, and the phenomenon of the internalized community agenda goes far toward answering that question. Under most circumstances, our national agenda of alternatives does not include the possibility of a military dictatorship; it embodies, rather, the shared value-the symbol, if you will -of civilian rule. And the military, who have historically perceived themselves as part of our society, also share in the consensus on that agenda. They do not agree, in other words, on courses of action that are "inconceivable" to them because not within the agenda they have internalized.

On the basis of the above analysis we may conclude that any study of the distribution of political power that does not include a detailed analysis of the origins and content of the community agenda must be adjudged incomplete. ${ }^{286}$ What is crucial, as one incisive analysis of Dahl's study of New Haven has put it, is an exploration of the ways in which "the dominant values and the political myths, rituals and institutions...tend to

285. Dahl, supra note 283 , at 465 (italies in original).

286. Cf. Simon, supra note 279 , at $510-12$. 
favor the vested interests of one or more groups, relative to others. ${ }^{\text {"287 }}$ It is precisely such an analysis that is lacking in Who Governs?

The ultimate source of the failure of Who Governs? fully to describe the distribution of power in New Haven is thus to be found in the focus, which Shapiro shares with Dahl, on the process rather than the actor, on interactions within a given system rather than on the component parts of that system. Such a focus permits a highly accurate description of the system as it actually operates at any given time. But it does not permit an assessment of whether the system is operating within proper limits, whether the community agenda is an equitable one, for any such assessment, as we have seen, would require the postulation of "real" as opposed to perceived interests.

Nor does such a focus, as our examination of Dahl's military-dictatorship example indicates, even permit satisfactory analysis of the question how the existing limits of the system are maintained. The continuing operation of the system, the internal checks and balances, of course limit the changes that can be introduced by any given component part. But if we inquire into the source of the particular set of existing checks and balances or ask why the actors accept the constraints represented by those checks and balances, we are led directly to the community agenda of alternatives: the consensus that defines the existing set of checks and balances and whose internalization by the actors results in the acceptance of the constraints that it imposes. ${ }^{288}$

287. Bachrach \& Baratz, supra note 278 , at 950 .

288. Cf. D. Truman, The Governmental Process 348-49 (I95I).

In one of the footnotes omitted from the quotation in the text accompanying note 282 supra, Polsby notes that the "current state of affairs" is not the only possible determinant of the "community agenda of alternatives": "Other plausible answers might be that the agenda of alternatives is determined by the ideologies of choosers; by the 'real' interests of choosers; by accident; by certain underlying 'structural' characteristics of the community (e.g., company town vs. dormitory suburb vs. metropolis). In presenting my own candidate for the best answer, I do not mean to exclude these possibilities. A theory that claimed some measure of comprehensiveness would probably have to consider the extent to which each of these factors determined the course of community decision-making." N. PoLSEY, supra note 272, at 134 ת.34.

But Polsby has previously found unacceptable at least one of these "plausible answers"- the "real" interests of choosers. Polsby's comment on an attempt by C. Wright Mills to delineate the possibility of a "false consciousness" on the part of a given social stratum is as follows: "Note the presumption that 'objective interests' exist; that there is a set of allegiances and actions which is appropriate for all members of a class. This presupposes a homogeneous set of 'accepted values' for all class members. Secondly, Mills presumes that these particular allegiances and actions 'have to be followed.' This means in effect that a 'best' strategy also exists. But are not these 'objective' circumstances actually constructs of the analyst?" Id.at 23 n.55 (italics in original).

The salient issue raised by Polsby's comment on Mills is the possibility that Polsby's agenda of alternatives is itself a "construct of the analyst." The short answer is that it clearly is. Certainly there exist no empirical data in direct support of the proposition that all members of any existing community share a single, coherent, and comprehensive body of values. Indeed, one of the most fascinating aspects of Who Governs?-Dahl's speculations in book VI on the sources of stability in pluralistic democracies -takes as its point of departure recent empirical findings indicating that "although Americans almost unanimously agree on a number of general propositions about democracy, they disagree about specific applications to crucial cases" and that "a majority of voters frequently hold views contrary to the rules of the game actually followed in the political system." R. DAHL, supra note 27 I, at 312 .

Dahl's hypothesis concerning the stability of those rules suggests that, although the majority of voters prefer different rules, their preference is not a strong one, in the sense that they are unwilling 
An analogous set of problems arises in connection with the "group" theory of politics, which explicitly underlies Shapiro's analysis of the Court's role in first amendment cases. ${ }^{280}$ The group theory simply assumes, on the part of groups within the society, the existence of a consensus about the legitimacy of the system that defines the conditions of their interaction. ${ }^{290}$ It assumes, in other words, that groups accept the constraints the system imposes on their possible goals and the methods to be followed in achieving those goals.

The difficulties involved in this assumption are most clearly apparent when group theorists attempt to account for a change in the consensusfor society's acceptance of, for example, a set of social, economic, or political demands that had formerly been unacceptable. Because group theory

to expend many resources to realize it; that no agreement exists regarding the desirability of any single set of alternatives; and that the politically active stratum of society, marked by a high degree of consensus concerning the desirability of the existing rules, is often capable of blocking changes because of its superior political skills and resources. Such a hypothesis, suggesting that "public" acceptance of democratic norms is really a matter of their acceptance by a strategically placed subpublic, could obviously be applied to Polsby's "community agenda of alternatives." But this is only to suggest that the agenda of alternatives is indeed an analytical construct, one that may or may not be verified by empirical data. It does not answer the question whether this particular construct is a valuable one.

The "community agenda of alternatives" does account for an empirically observable phenomenon, the fact that "[s] ome, perhaps most, possible courses of action are never considered in community decision-making ...." N. PoLsBY, supra note 272 , at 133 (italics in original). Dahl's hypothesis suggests that Polsby's explanation (that most possible courses of action are inconceivable to the actors involved because those actors share a community agenda) represents a considerable simplification of a complex reality involving the agendas held by various subpublics, the intensity of the preference of each subpublic for its own agenda (in terms of willingness to expend resources to realize it), and the ability of each subpublic (in terms of access to sufficient resources) to enforce that preference. The methodological difficulties involved in giving empirical content to any of these categories are, to say the least, considerable. Given the absence of data-and the comprehensiveness of Dahl's categories suggests that the vacuum will not soon be filled-a first approximation, a simplification such as that represented by the "community agenda of alternatives," may therefore be good enough. Dahl's hypothesis, after all, in the absence of empirical data, must remain just that-a hypothesis.

Whether a given construct is good enough depends on what questions that construct is being used to answer. Thus, the "public" whose acceptance of Court decisions has often been referred to in this Article is as much an analytic construct as the "public" whose acceptance of democratic norms Dahl has further analyzed in terms of subpublics. Because this Article is concerned with the empirical phenomenon of public reaction to Court opinions only insofar as the existence of that phenomenon requires certain conclusions about the proper role of the Court, detailed analysis of the components of that "public" seems unnecessary. Conversely, there are inquiries for which Dahl's categories of "political professionals, the political stratum, and the great bulk of the population," R. Darr, stipra note 271, at 316, will lack adequate precision.

The point, then, is that labeling a category a "construct of the analyst" poses the question rather than answers it. Any general category that purports to encompass a larger group of events than those actually studied represents, in Polsby's sense, a "construct of the analyst" as to those cvents that have not actually been observed. Further, in a sense that may or may not be different, even categories that refer only to actually observed events represent constructs of the observer. The question in each case can only be whether the construct adequately accounts for the phenomenon it is being used to describe.

The construct of the "community agenda of alternatives" adequately accounts for the phenomenon that most possible courses of action are never considered in community decisionmaking, if the focus of inquiry is on the process of decisionmaking, on "how" those decisions get made. That the analysis offered by Dahl and Polsby is inadequate to answer the question "why" decisions get made, to account for the fact that certain decisions are inconceivable, is the argument made in part VIII of this Article. As an answer to that question, the construct of a "community agenda of alternatives" is of course unsatisfactory, since the question at issue is precisely what factors determine the content of that agenda. What is striking is that Polsby should regard as a "plausible answer" to that question the very hypothesis of "real" interests that underlies so much of social-stratification theory.

289. See text accompanying notes I4-I6, 244 supra.

290. See Rothman, Systematic Political Theory: Observations on the Group Approach, 54 Ax. PoL. Sci. REv. I5, 28-29 (1960). 
postulates that all social attitudes are the product of group membership, the shift in attitudes implied by the acceptance of such demands is accounted for in terms of the crystallization of what had previously been only a "potential" group. Shapiro, for example, explicitly resorts to the concept of potential groups in defining the Court's group "clientele."

The difficulty with this construct, however, is that it fundamentally contradicts the postulate that attitudes are derived solely from group membership, for a potential group is in essence nothing more than a shared attitude that at some point may lead to membership in, and activity as, a group. For potential groups, therefore, attitudes precede group formation, rather than follow from group membership. ${ }^{292}$ The root of the difficulty, once again, is the refusal of group theorists to examine the origins and content of the community agenda that defines the conditions for group interaction, and the degree to which that agenda has been internalized by participants in such interaction. Potential groups simply represent potential changes in the community agenda, and an adequate account of their crystallization therefore crucially involves a description of the psychological mechanisms in terms of which changes are introduced into individuals' perceptions of the norms and goals of the society in which they live, the roles they are to play within that society, and the constraints society has imposed upon those roles.

It is such mechanisms of internalization that provide the ultimate answer to the fears of judicial discretion that underlie Black's insistence on "logic" rather than experience. Of course both the existence of other agencies pursuing their own interests-the checks Shapiro postulates as limiting judicial overstepping of legitimate boundaries-and the threat of a massively unfavorable public response do place some constraints on the abuse of that discretion. But those constraints, as the experience of the r93o's demonstrated, operate only belatedly and in the most extreme circumstances. Therefore, if we are concerned about the day-by-day operation of the Court, about the routine decision rather than the isolated, spectacular exception, the question whether the Court will confine itself to those decisions the society regards as legitimately within its authority can ultimately be answered only by examining the extent to which individual Justices have internalized the community consensus that defines the Court's sphere of competence.

It is striking, for example, that immediately upon assuming his seat on the Court, Senator Black was certain that he had assumed a wholly different governmental role. To some extent, awareness of the content and limits of the judicial role can be ascribed either to prior judicial experience

292. For a more detailed exposition of this analysis see Rothman, supra note 290, at 23-25. 
or to what might be designated "on-the-job learning." However, in Black's case at least, it is unlikely that much significance can be ascribed to his service, in IgIo and IgII, as a police-court judge in Birmingham, Alabama.

Similarly, there are serious diffculties involved in attempts to derive this awareness from the institutional experiences that Justices undergo during their service on the Court. It is true that much can be learned from an examination of the pressures exerted on a Justice by the institution of the Court, and we already possess studies that considerably advance our knowledge in this area. ${ }^{293} \mathrm{We}$ could presumably learn even more from an accurate and detailed study of the changes in life style that result from appointment to the Court-changes in luncheon partners, dinner guests, and recipients and initiators of telephone conversations, for example. UItimately, however, the value of such studies must be considerably less than in the case of a Congressman, for example, or the head of an administrative agency, primarily because the Court as an institution imposes far less pressure on a member than does the social system that is Congress or the interlocking web of bureaucratic and client pressures that constitutes an administrative agency.

The utility of studies such as those suggested above is severely limited, then, by facts already noted: The Court, unlike Congress, is not a social system; the task of a Justice is far more an individual than a group endeavor; and the influence of other Justices and of the institution on a new member of the Court is correspondingly limited. ${ }^{294}$ To a far greater extent than is true in the case of a Congressman, therefore, the search for factors that effectively impose restraints on the discretion of the individual Justice must be carried beyond the realm of his work experience to that of his schooling, both formal and informal. Such an investigation, a branch of the study of political "socialization," might profitably begin with an examination of the impact of their professional training on given Justices. For example, to what extent can a particular Justice's perception of the range of discretion he can legitimately exercise be ascribed to a professional training that was primarily "policy-oriented"?

Given the growing awareness on the part of the profession as a whole of the discretion that necessarily inheres in common-law methods of adjudication, it seems unlikely that the study proposed above would produce any startling results. But such a study would at least represent a start toward explorations of far earlier and less formal learning experiences from which more relevant information might be obtained. To propose studies of child-

293. See, e.g., Danelski, The Influence of the Chief Justice in the Decisional Process, in Cousts, Judges, AND Polritcs (W. Murphy \& C. Pritchett eds. 196r); Murphy, Marshaling the Cont: Leadership, Bargaining, and the Judicial Process, 29 U. Cin. L. REv. 640 (1962); Snyder, The Supreme Cout as a Small Group, 36 Soctal Forces 232 (1958).

294. See text accompanying notes $247-48$ supra. 
hood learning experiences is not, of course, to suggest that there do not exist formidable methodological problems that would first have to be overcome. It is to suggest only that such studies will ultimately prove necessary if we insist on definitive answers to the dilemma posed by the possibility of judicial discretion.

As the decisions of the Court increasingly lose the appearance of "logic" that has historically constituted the basis for their public acceptability, studies of the institutional differences between Congress and the Court ${ }^{295}$ and of the extent to which the Justices have internalized the constraints on their power implicit in those institutional differences could thus gradually serve to replace appearance with reality, could in time make possible the discarding of those symbols in terms of which the Court's authority has historically been accepted by the public. Even if studies both of childhood learning experiences and of the functioning of the Court as an institution could in principle provide us with complete and coherent descriptions, however, would there not remain significant limitations on the efficacy of those studies?

Thus, as we have seen, the symbols such studies would regard as meaningless abstractions-the need to achieve "logic" in judicial decisions that they would be explaining away-in fact perform a function that is vitally necessary: the function of continually reminding participants in government of the overriding social values our society seeks to impose upon the governmental process, of the ideals in terms of which we desire to be ruled. ${ }^{230}$ The Supreme Court's conferences are conducted in secret, and the Latin in which the Roman Catholic Mass was formerly invariably conducted presumably veiled from many of the participants in that rite the meaning of the words being spoken. But is the saying of the Mass in the vernacular now the beginning, or the end, of the relevance of that sacrament to the lives of believers?

That the limits on the utility of such studies continue to be observed, that the processes of the Court not be completely open to public view, is, moreover, no less important for the Justices than for the public they serve. For the short of the matter is that trust has a meaning for both partners to a relationship. If a government based on consent is to survive, the "Morality Play" must have content for the actors as well as for the audience. And that content, as we have seen, ${ }^{297}$ is based precisely on the possibility of abuse of discretion.

295. See, e.g., id.

296. See text accompanying notes $24 \mathrm{r}-43$ supra.

297. See the concluding paragraphs of part VII-A, following note 243 supra. 